\title{
O ecossistema de startups de software da cidade de São Paulo
}

\author{
Monna Cleide Fonseca \\ Rodrigues dos Santos
}

DisSERTAÇÃO APRESENTADA

$\mathrm{AO}$

Instituto De Matemática e EstatísticA

DA

Universidade DE SÃo PAUlo

PARA

OBTENÇÃO DO TÍTULO

DE

Mestre em Ciência da Computação

Orientador: Prof. Dr. Fabio Kon

Durante o desenvolvimento deste trabalho a autora recebeu auxílio financeiro do CNPq

São Paulo, 17 de fevereiro de 2016 



\section{O ecossistema de startups de software da cidade de São Paulo}

Esta versão da dissertação contém as correções e alterações sugeridas pela Comissão Julgadora durante a defesa da versão original do trabalho, realizada em 26/11/2015. Uma cópia da versão original está disponível no Instituto de Matemática e Estatística da Universidade de São Paulo.

Comissão Julgadora:

- Prof. Dr. Fabio Kon (orientador) - IME-USP

- Profa. Dra. Luciane Meneguin Ortega - EACH-USP

- Prof. Dr. Paulo Lemos - UNICAMP 



\section{Resumo}

O empreendedorismo e a cultura de inovação ganham cada vez mais lugar na realidade econômica mundial. Grandes centros inovadores, como o Vale do Silício, nos Estados Unidos, e Tel-Aviv, em Israel, surgem como modelos para outras nações que pretendem introduzir definitivamente o empreendedorismo como uma cultura local. Nesta dissertação, uma nova metodologia de coleta e análise de dados proposta pelo Grupo de Pesquisa em Empreendedorismo do IME-USP foi refinada e utilizada para desenvolver um modelo do ecossistema de startups de software da cidade de São Paulo. Para tanto, os dados que compõem o modelo foram reunidos através de pesquisa qualitativa com membros e fundadores de startups, aceleradoras, investidores de risco e outros agentes importantes para o ecossistema. Os resultados do estudo constatam que a cidade possui todos os elementos fundamentais para o ecossistema empreendedor, tais como instituições, clientes interessados em experimentar novos produtos, a presença de importantes agentes financeiros, e um ambiente promissor; no entanto, ainda é necessária uma melhor conexão entre esses componentes, e certos problemas críticos de grandes metrópoles, tais como a mobilidade urbana e o alto custo de vida, precisam ser melhorados para que o ecossistema da cidade possa continuar progredindo. A dissertação conclui com sugestões de ações para a melhoria do ecossistema, baseadas nos comentários dos entrevistados e em recomendações de outros estudos e relatórios com foco similar.

Palavras-chave: empreendedorismo, ecossistemas de inovação, startups, software, Tecnologia da Informação, TI, São Paulo. 



\section{Abstract}

Entrepreneurship and the innovation culture are increasingly gaining ground in the global economy. Great innovative centers, such as the Silicon Valley, in the United States, and Tel-Aviv, Israel, arise as models for other nations wishing to definitely introduce entrepreneurship as part of the local culture. In this thesis, a new methodology for collecting and analyzing data proposed by the IME-USP Entrepreneurship Research Group was refined and used to build a model of the software startups ecosystem in São Paulo, Brazil. Data that make up the model were gathered through qualitative research with members and founders of startups, accelerators, venture capitalists and other important agents of the ecosystem. The study findings show that the city possesses all vital elements for the entrepreneurial ecosystem, such as institutions, customers interested in experimenting new products, the presence of important financial agents, and a promising environment; however, better connections among these components are required, and certain critical problems common in very large cities need to be improved so that the city's ecosystem can continue evolving. The thesis concludes by suggesting concrete actions for the improvement of the ecosystem based on the results from the qualitative research.

Keywords: entrepreneurship, innovation ecosystems, startups, software, Information Technology, IT, São Paulo, Brazil. 



\section{Agradecimentos}

Primeiramente, obrigada a Deus por todas as oportunidades vividas até aqui.

Quero agradecer imensamente a meus familiares, por todo o apoio incondicional que me ofereceram durante todo esse período. Por todas as "pontes aéreas" dos meus pais, e pelo apoio e carinho incondicionais dos meus avôs, especialmente minha avó. Sem seu suporte e apoio emocional, eu certamente não estaria escrevendo esse texto. Estendo também um agradecimento especial à minha tia Vera, que me deu a coragem para tentar o que na época me parecia impossível: entrar no mestrado na Universidade de São Paulo.

Tenho muito a agradecer aos vários colegas feitos no IME, em especial no laboratório do CCSL. Muitos já até mesmo estão formados ou passando uma temporada de estudos fora, mas quero que saibam que guardo todos na lembrança com muito carinho. Recebi deles lições e dicas que irão muito além da minha vida acadêmica. Mas meu maior agradecimento dentro da universidade é sem dúvidas ao meu orientador, prof. Fabio Kon, que além de ótimo orientador é um excelente músico. Você sempre foi compreensivo e atencioso tanto nas horas boas quanto ruins, dentro e fora da universidade. Não há palavras que possam resumir tudo que tenho a lhe agradecer por todo esse tempo.

Um obrigado muito especial a meu namorado, Victor Romero, que tanto me apoiou e me motivou, mesmo antes de sequer sabermos os nomes um do outro. Você foi a pessoa que mais esteve presente, e seria fácil escrever algumas páginas contando tudo que você fez por mim nesses quase três anos. Creio que você foi minha segunda maior conquista durante o mestrado. :)

Gostaria de agradecer a todos os colegas que estiveram ao meu lado durante essa época, em especial a Ruben Salas e Lina Susana, Lene Lima, Marcos Amarís e Higor Amario. Aos colegas Emilio Francesquini, Vinícius Pinheiro e Carlos Eduardo Santos (saibam que o HabitRPG, hoje Habitica, mudou minha vida), Nelson Lago, Leonardo Leite, Elaine Watanabe, Albert de la Fuente, e ao conterrâneo Bosco Pereira. Aos amigos empreendedores Alan Leite, Daniel Cukier, Artur Vilas Boas, Andrea Resende e Augusto Júnior. A todos, obrigada por compartilhar de seu tempo comigo, por toda a ajuda oferecida, por todas as revisões, dicas de português, textos, códigos e por todos os momentos em que estiveram presentes.

Agradeço também aos professores Paulo Lemos e Luciane Meneguin, por suas relevantes contribuições para a conclusão deste trabalho.

Querida vovó Santina, quero que saiba que este trabalho é inteiramente dedicado a 
você. Obrigada por sempre estar comigo, do fundo do meu coração. 


\section{Sumário}

Lista de Figuras $\quad$ ix

Lista de Tabelas $\quad$ xi

Lista de Abreviações $\quad$ xiii

Glossário $\quad$ XV

1 Introdução 1

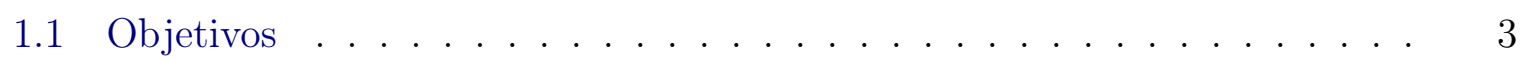

1.2 Motivação . . . . . . . . . . . . . . . . . . . . 4

1.3 Organização do trabalho . . . . . . . . . . . . . . . . . . . 6

2 Empreendedorismo e ecossistemas de inovação $\quad 7$

2.1 Empreendedorismo e o empreendedor . . . . . . . . . . . . . . 7

2.2 Startups . . . . . . . . . . . . . . . . . . . . . . 10

2.2.1 Ciclos de vida . . . . . . . . . . . . . . . . . . . . . . . 12

2.3 Inovação . . . . . . . . . . . . . . . . . . . . . . . 15

2.4 Ecossistemas de inovação e aglomerados industriais . . . . . . . . . . . . 16

2.5 São Paulo como ecossistema empreendedor . . . . . . . . . . . . . . . . . 17

3 Metodologia $\quad 21$

3.1 Construção da pesquisa . . . . . . . . . . . . . . . . . . . . . . . 21

3.2 Entrevistas . . . . . . . . . . . . . . . . . . 22

3.3 Codificação e análise dos dados . . . . . . . . . . . . . . 26

3.4 Análise e resultados . . . . . . . . . . . . . . . . . . . . 28

3.4.1 Metodologias relacionadas . . . . . . . . . . . . . . . . 28

4 Resultados $\quad 33$

4.1 Respostas das perguntas de pesquisa . . . . . . . . . . . . . . 33

4.2 Mapa do ecossistema de São Paulo . . . . . . . . . . . . . . . . . . . 47

4.2.1 Análise do ecossistema de São Paulo . . . . . . . . . . . . . . . 47 
5 Conclusões $\quad 59$

5.1 Contexto socioeconômico atual do ecossistema . . . . . . . . . . . . 59

5.1 .1 Financiamento . . . . . . . . . . . . . . 60

5.1 .2 Educação . . . . . . . . . . . . . . . . . 61

5.1 .3 Tecnologia . . . . . . . . . . . . . . . . 64

Considerações finais . . . . . . . . . . . . . . . . . . . 64

$\begin{array}{ll}\text { Referências Bibliográficas } & 67\end{array}$ 


\section{Lista de Figuras}

1.1 Índice global de ecossistemas de startups . . . . . . . . . . . . . . 5

2.1 Quadro do modelo de negócios . . . . . . . . . . . . . . . . . 9

2.2 Ciclo de vida de uma startup apresentado por Steve Blank . . . . . . . . 13

2.3 Ciclo de vida de uma startup apresentado por Thomas Schranz . . . . . . 14

2.4 Índice de Cidades Empreendedoras Endeavor . . . . . . . . . . . . . . . . 17

2.5 Ranking global de ecossistemas de startups . . . . . . . . . . . . . . 18

3.1 Nota de exemplo na plataforma Evernote . . . . . . . . . . . . . . . . 27

3.2 Planilha de codificação de dados . . . . . . . . . . . . . . . . . . 29

4.1 Domínios do ecossistema empreendedor . . . . . . . . . . . . . . 33

4.2 Arcabouço conceitual simplificado . . . . . . . . . . . . . . . 47

4.3 Sentido de leitura do mapa do ecossistema . . . . . . . . . . . . . . 48

4.4 Eixo 1 - Educação . . . . . . . . . . . . . . . . . . . 48

4.5 Eixo 2 - Empresas . . . . . . . . . . . . . . . . . . . . . . 49

4.6 Eixo 3 - Leis e financiamento . . . . . . . . . . . . . . . 50

4.7 Eixo 4 - Empreendedor . . . . . . . . . . . . . . . 51

4.8 Eixo 5 - Startup . . . . . . . . . . . . . . . . . . 52

4.9 Mapa do ecossistema de startups de software de São Paulo . . . . . . . . 54

4.10 Mapa do ecossistema de startups de software de Israel . . . . . . . . . . . 56

4.11 Arcabouço conceitual de ecossistemas de startups . . . . . . . . . . . 58

5.1 Índice de cidades empreendedoras segundo o ambiente regulatório . . . . 60 



\section{Lista de Tabelas}

3.1 Distribuição de entrevistados e seus papeis no ecossistema . . . . . . . . 23

3.2 Quantidade de entrevistas feitas por aluno . . . . . . . . . . . . 23

3.3 Estágios de financiamento das startups participantes no estudo . . . . . . 24

3.4 Estágios de crescimento das startups participantes no estudo . . . . . . . 24

3.5 Comparação entre metodologias de avaliação de ecossistemas . . . . . . . 31

4.1 Principais aceleradoras em São Paulo . . . . . . . . . . . . . . . 36

4.2 Principais organismos de investimento em São Paulo . . . . . . . . . . . 38

4.3 Principais instituições de empreendedorismo em São Paulo . . . . . . . . 39

5.1 Sugestões de ações para a melhoria do ecossistema . . . . . . . . . . 66 



\section{Lista de Abreviações}

ABRAII Associação Brasileira de Empresas Aceleradoras de Inovação e Investimento

ABStartups Associação Brasileira de Startups

ANPEI Associação Nacional de Pesquisa e Desenvolvimento das Empresas Inovadoras

BNDES Banco Nacional de Desenvolvimento Econômico e Social

CEO Diretor executivo (Chief Executive Officer)

CTO Diretor técnico ou diretor-chefe de tecnologia (Chief Technology Officer)

CASE Conferência Anual de Startups e Empreendedorismo

FAPESP Fundação de Amparo à Pesquisa do Estado de São Paulo

Finep Financiadora de Estudos e Projetos

GEM Global Entrepreneurship Monitor

IPO Oferta pública inicial (Initial Public Offering)

MCTI Ministério da Ciência, Tecnologia e Inovação

MDIC Ministério do Desenvolvimento, Indústria e Comércio Exterior

MIA Mulheres Investidoras Anjo

MVP Mínimo produto viável. Piloto testável de uma solução (Minimum Viable Product)

NEU Núcleo de Empreendedorismo da USP

OECD Organização para o Desenvolvimento e Cooperação Econômica (The Organisation for Economic Co-operation and Development)

ONU Organização das Nações Unidas

PIB Produto Interno Bruto

PIPE Programa Pesquisa Inovativa em Pequenas Empresas, da FAPESP

PRODESP Companhia de Processamento de Dados do Estado de São Paulo

P\&D Pesquisa e Desenvolvimento

Sebrae Serviço de Apoio às Micro e Pequenas Empresa

SPTrans São Paulo Transporte. Gestora do sistema de transporte público por ônibus da capital paulistana

TI Tecnologia da Informação

VC Investidor de risco (Venture Capital) 



\section{Glossário}

Benchmarking Execução de programas, sistemas ou operações para analisar o desempenho de um objeto

Bootstrapping Financiamento inicial exclusivamente com recurso próprio, sem ajuda externa

Dream Team Time dos sonhos. Suposta configuração ideal para um time de fundadores de uma startup

Early Adopter Usuário inicial. Em geral, os primeiros que se tornam adeptos a uma determinada tecnologia

Exit

Saída. Momento da venda de uma startup a outra empresa

Hackathon

Maratona de programação. Derivado da junção das palavras hack (forma de programar) e marathon (maratona)

Mindset

Estado mental, configuração mental. Conjunto de crenças e valores de uma pessoa em determinado momento de vida

Networking Evento ou ação voltada para ampliar a rede de contatos do participante

Pitch

Fala de elevador. Apresentação curta de uma ideia de startup

Podcast Programas temáticos em formato de áudio distribuídos pela internet

Spin-off Empresa derivada de grupos de pesquisa públicos ou privados

Startup Weekend Evento focado na criação de uma startup em 54 horas

Survey Pesquisa. Metodologia que busca informações sobre características, opiniões ou ações de um determinado grupo de pessoas

Trace Rastreio, rastrear. Corresponde a relatórios de monitoramento da execução de um ou mais programas 



\section{Capítulo 1}

\section{Introdução}

O empreendedorismo tecnológico encontra-se cada vez mais presente no cenário econômico brasileiro. A criação de novas empresas amplia as modalidades de negócios, explora novos mercados, traz desenvolvimento para a indústria e benefícios para a balança comercial. Além disso, o empreendedorismo a nível global acarreta em um forte impacto social ao promover, a longo prazo, o desenvolvimento interpessoal, interferindo diretamente na cultura e nos costumes locais [AH08].

Na década entre 2002 e 2012, o Brasil usufruiu de uma economia relativamente estável, favorecendo o consumo e o surgimento de novos negócios [GAM12]. Mesmo com a atual desaceleração iniciada em 2013 os índices de surgimento de novos negócios continuam sendo positivos [MGA $\left.{ }^{+} 13\right][$ Com15]. Os últimos anos trouxeram também uma consolidação do mercado interno, que em 2012 apresentava por volta de 100 milhões de consumidores com o perfil da chamada "classe média". Ao mesmo tempo, o desenvolvimento econômico das camadas menos favorecidas da população acarretou novas oportunidades de mercado.

Ainda assim, apenas essas condições favoráveis não bastam para inserir o país efetivamente na nova economia do Século 21; o país apresenta problemas crônicos, tais como a alta carga tributária, burocracia elevada, infraestrutura deficiente e a dificuldade em obter investimento financeiro nas etapas iniciais [GAM12], além dos índices educacionais baixos e as metas não atingidas apontadas no último Índice de Desenvolvimento da Educação Básica $(\mathrm{IDEB})^{1}$. Esses problemas precisam ser combatidos para colocar a nação mais próxima de uma realidade em que o empreendedorismo seja uma opção de carreira palpável para mais e mais pessoas.

As startups começam a despontar como uma alternativa viável de carreira profissional. Apesar de já existirem startups de tecnologia desde a década de 1980 no Brasil, os investimentos e a ampla divulgação da mídia nos últimos 5 anos tem ampliado as discussões sobre o assunto. Alguns pontos importantes que mostram esse crescimento em todo o Brasil, e particularmente no estado de São Paulo, são, por exemplo:

- A criação de novos fundos de investimento no país, podendo-se destacar Fir Capital (1999), Monashees (2005), Confrapar (2006), A7Capital (2007), Trindade Investimentos (2010), 21212 (2011), etc.

- A entrada de fundos de investimento estrangeiros, dentre os quais Accel (2011), Redpoint e.ventures (2012), Qualcomm Ventures (2012) e Kaszek (2012).

- A criação de aceleradoras brasileiras, tais como Startup Farm (2011), Aceleratech (2012), Acelera-MGTI e WOW (2013), Abril Plug \& Play (2014) e Oxigênio (2015), e a entrada da Wayra no Brasil (2012).

\footnotetext{
${ }^{1}$ http://ideb.inep.gov.br/resultado/, último acesso em 11/08/2015.
} 
- O surgimento de grupos de investidores anjo, como o Anjos do Brasil (2011) e o Curitiba Angels (2014).

- A criação dos programas "Start-Up Brasil" (2012), dentro do programa TI Maior, do Ministério da Ciência, Tecnologia e Inovação, e SEED, em Minas Gerais (2013).

- O aumento significativo no número de projetos apoiados pela FAPESP no Programa PIPE (Pesquisa Inovativa em Pequenas Empresas) de 2010 a 2015.

- O surgimento de um espaço para startups na Campus Party, em 2011, mantido pelo Sebrae. Em 2012, o espaço foi ampliado e batizado de Campus Empreendedorismo, e segue em crescente expansão. Para os anos de 2015 e 2016, o evento apresenta um palco exclusivo voltado para palestras na área e maratonas de negócio.

- A abertura de um Campus do Google para startups anunciada em 2014, com inauguração prevista para 2015.

- O lançamento do Tech Sampa (2014), uma política da prefeitura de São Paulo de fomento à criação de startups ${ }^{2}$.

- A inauguração do Cubo (2015), espaço de coworking organizado pelo banco Itaú em parceria com a Redpoint e.ventures, sendo a primeira iniciativa do tipo na América Latina.

- O lançamento do Pitch Gov SP (2015), um programa organizado em conjunto pelo Governo de São Paulo (através da Secretaria de Governo), a PRODESP (companhia de TI do estado de São Paulo) e a ABStartups (Associação Brasileira de Startups) que visa a atrair soluções inovadoras nas áreas de educação, saúde e facilidades ao cidadão ${ }^{3}$.

- O anúncio da primeira edição da São Paulo Tech Week (2015), uma semana que concentra iniciativas e eventos relacionados à tecnologia, dentre eles o CASE (Conferência Anual de Startups e Empreendedorismo), a maior conferência de empreendedorismo da América Latina. A semana é organizada pela SP Negócios (órgão da prefeitura responsável por investimento e negócios na capital) e a Investe São Paulo, agência do Governo do Estado de São Paulo.

- O fortalecimento de agências de inovação em universidades públicas, tais como a Agência USP de Inovação ${ }^{4}$ e a Agência de Inovação INOVA Unicamp ${ }^{5}$.

- A criação de iniciativas públicas focadas para o desenvolvimento de empresas, tais como Desenvolve $\mathrm{SP}^{6}$ e Investe $\mathrm{SP}^{7}$.

Empreendedores geralmente trabalham sob condições de pouca ou nenhuma certeza [Rie11]. Isso muitas vezes se dá por serem pessoas que estão interessadas em inovação e ao mesmo tempo terem a coragem de correr riscos. Assim, o empreendedor se torna cada vez mais um dos principais agentes para o processo inovativo hoje, pois ele busca e desenvolve

\footnotetext{
${ }^{2}$ http://www.capital.sp.gov.br/portal/noticia/3619, último acesso em 12/08/2015.

${ }^{3}$ http://pitchgov.sp.gov.br/, último acesso em 19/10/2015.

${ }^{4}$ http://inovacao.usp.br/

${ }^{5} \mathrm{http}: / /$ www.inova.unicamp.br/

${ }^{6} \mathrm{http:} / /$ www.desenvolvesp.com.br/

${ }^{7}$ http://www.investe.sp.gov.br/
} 
novos produtos e processos; busca recursos com outros agentes, sejam eles financeiros, tecnológicos, acadêmicos ou humanos; e explora novos mercados com o seu produto final [Aub10]. Portanto, o impacto que esse tipo de negócio traz ao desenvolvimento da região em que se encontra geralmente é muito maior do que o de empresas convencionais, pois além do aumento na atividade econômica, elas trazem consigo um incentivo à pesquisa. A base desses negócios inovadores está muitas vezes nos novos produtos que apresentam para o mercado e no investimento de risco que possibilita seu desenvolvimento.

Pesquisa e inovação estão amplamente ligados. A inovação tecnológica é fortemente responsável por manter a competitividade das empresas, por representar uma vantagem competitiva através da geração de valor, e é vital para o crescimento sustentável da economia global [LM01]. O desenvolvimento de novas tecnologias é uma das ferramentas fundamentais para o desenvolvimento da indústria, que por sua vez está atrelado à geração de novos negócios e postos de trabalho. Essa é a economia de inovação, que fundamenta-se principalmente na transformação de conhecimento em produtos.

A recente fundação e chegada de novas aceleradoras, investidores anjo e fundos de capital de risco ao país traz novas alternativas para quem deseja evoluir de startup a empresa. Outras formas de investimento locais também atraem os interesses do possível empreendedor, tais como programas de fomento do governo federal e governos estaduais e de agências de desenvolvimento econômico, que começam a se destacar na grande mídia. Essas organizações trazem um grande benefício à comunidade empreendedora, muitas vezes disponibilizando cursos e materiais de aprendizado, organizando eventos de networking e mentorias, e apresentando empreendedores a possíveis investidores.

A necessidade de inovação traz à tona o surgimento de um ecossistema próprio. A inovação não existe sozinha: ela depende de todo o ambiente ao redor para se desenvolver e gerar ainda mais inovação, atraindo pessoas, recursos e oportunidades de fomento [MC08]. O ecossistema de inovação envolve esse equilíbrio entre os esforços de pesquisa e a implantação da inovação no mercado e no cotidiano das pessoas.

\section{$1.1 \quad$ Objetivos}

Espera-se através deste trabalho fornecer um arcabouço conceitual do ecossistema de inovação da cidade de São Paulo, com particular foco em startups de software, através da análise de vários âmbitos do ecossistema e de aspectos que o influenciam, sendo eles: fatores socioculturais, educação, características dos empreendedores e de times inovadores, aspectos tecnológicos e metodológicos, dentre outros.

Para evidenciar essas características, apresenta-se nesse documento:

- O mapa conceitual do ecossistema de startups de software da cidade de São Paulo, que consiste na apresentação de elementos-chave que permeiam o ecossistema e suas relações;

- A visão dos entrevistados acerca dos elementos da cidade e suas influências, intercalados com artigos e outros estudos complementares;

- Sugestões de ações concretas e políticas públicas.

Assim, espera-se oferecer uma contribuição significativa para o desenvolvimento econômico e social da cidade de São Paulo e contribuir para que essa comunidade se destaque cada vez mais como uma referência em empreendedorismo, similar ao que hoje acontece no Vale do Silício, em Tel-Aviv e em outros lugares do globo. 
A importância do software no mundo atual transforma-se de luxo a necessidade a cada momento. A tecnologia segue transformando paradigmas, seja nos estudos, através de ferramentas de educação à distância, softwares de simulação voltados para educação, plataformas de pesquisa e acesso a conteúdo, e muitas outras; no lazer, através de canais como Youtube e redes sociais; e no trabalho, onde o software garante velocidade de análise, processamento, divulgação e produção, sendo assim um grande diferencial de competitividade para empresas.

Uma prova disso pode ser obtida através das notícias. Em 2001, o jornal The New York Times já apontava o forte vínculo entre a computação e as outras áreas, no artigo All Science Is Computer Science 8 (em tradução livre, "Toda ciência é ciência da computação"). Com o passar dos anos, entretanto, nota-se uma nova transformação nessa relação, apontada pela revista Forbes, que afirma que "agora toda empresa é uma empresa de software" 9 . Assim, analisar ecossistemas de startups de software é analisar startups de alto conteúdo tecnológico.

Todos esses fatores, aliado ao fato do grupo de pesquisa em empreendedorismo responsável por esse estudo ser vinculado ao departamento de Computação do IME-USP, justificam o foco da pesquisa no setor de software.

\subsection{Motivação}

Ter o próprio negócio já é o sonho de $43 \%$ dos brasileiros, atrás apenas de viajar pelo país e comprar a casa própria [GAM12]. Ao mesmo tempo, o empreendedorismo por oportunidade, aquele em que o empreendedor vislumbra um momento adequado para investir, está gradativamente superando o empreendedorismo por necessidade, no qual o negócio é criado para suprir as necessidades financeiras do dono. Em 2013, mais de 70\% da população tinha como motivação a percepção de oportunidades futuras [MGA $\left.{ }^{+} 13\right]$.

O clima econômico favorável presente no país até meados de 2012 incentivava o trabalhador a se arriscar em novas oportunidades. Mesmo em 2013, com o início da desaceleração da economia brasileira, o clima era considerado positivo para quem desejava empreender [GAM12, MGA+13]. Entretanto, o cenário econômico brasileiro hoje é extremamente desafiador para o empreendedor, por conta do chamado "aperto monetário" (aumento dos impostos, comprometendo mais a renda do consumidor), a crescente inflação, a valorização do dólar, o rebaixamento de notas de crédito, dentre outros fatores [SEB15].

O mesmo acontece em relação ao empreendedorismo tecnológico. Por um lado, os altos juros, que fazem com que seja mais difícil obter financiamento para negócios de risco, e a insegurança sobre se perder o emprego, que fazem com que as pessoas procurem posições mais estáveis e de menor risco, são forças contrárias ao empreendedorismo.

Apesar das circunstâncias desfavoráveis, este ainda pode ser um bom momento para começar um novo negócio. A recessão pode trazer oportunidades de investimento em mercados específicos (ex.: treinamentos em vendas e divulgação de conteúdo, para prospecção de novos clientes, ou diminuir o custo através de soluções para redução de consumo de luz elétrica e/ou água). Especialistas também apontam que abrir um negócio hoje faria com que o momento de equilíbrio da empresa coincidiria com a saída do período de crise, e que deixar de empreender para manter-se em um cargo privado pode não ser a melhor

\footnotetext{
${ }^{8}$ http://www.nytimes.com/2001/03/25/weekinreview/the-world-in-silica-fertilization-all-science-is-computer-science. html

${ }^{9}$ www.forbes.com/sites/techonomy/2011/11/30/now-every-company-is-a-software-company/
} 
opção com a tendência ao aumento de demissões [Dor15, Amé15].

Os consumidores brasileiros se interessam por experimentar novos produtos e serviços, valorizam a inovação e recebem bem a oportunidade de testar um produto desenvolvido por uma empresa nova no mercado [GAM12]. Essa pode ser uma boa chance para empreendedores que tenham um diferencial forte, como um preço melhor que o da concorrência ou a economia de tempo ou recursos. A alta do dólar, que encarece os produtos importados, também abre espaço para o surgimento de concorrentes nacionais.

Adicionalmente, a crise faz com que as empresas busquem maior competitividade e maior eficiência, e a TI é um dos principais caminhos para isso; portanto, startups de software tem um fértil terreno para se desenvolverem, e a demanda por inovações em TI segue em expansão.

Apesar de termos vários polos empreendedores distribuídos por todo o território nacional, São Paulo é o de maior destaque, tendo obtidos excelentes posições em estudos nacionais e internacionais [End14] [Com15]. Um exemplo disso é o Índice global de ecossistemas de startups (Figura 2.4), realizado pela Compass.co, especializada na análise de ecossistemas de empreendedorismo, que aponta a cidade com um dos 20 melhores ecossistemas globais. O índice será melhor discutido no decorrer deste documento.

\begin{tabular}{lcl}
\hline Cidade & Posição & Mudança \\
\hline Vale do Silício & 1 & $\triangleleft$ \\
Nova Iorque & 2 & $\triangle 3$ \\
Los Angeles & 3 & $\triangleleft$ \\
Boston & 4 & $\triangle 2$ \\
Tel Aviv & 5 & $\nabla 3$ \\
Londres & 6 & $\triangle 1$ \\
Chicago & 7 & $\triangle 3$ \\
Seattle & 8 & $\triangle 4$ \\
Berlim & 9 & $\triangle 6$ \\
Cingapura & 10 & $\triangle 7$ \\
Paris & 11 & $\triangleleft$ \\
São Paulo & 12 & $\triangle 1$ \\
Moscou & 13 & $\triangle 1$ \\
Austin & 14 & Novo \\
Bangalore & 15 & $\triangle 4$ \\
Sidney & 16 & $\triangle 4$ \\
Toronto & 17 & $\nabla 9$ \\
Vancouver & 18 & $\nabla 9$ \\
Amsterdã & 19 & Novo \\
Montreal & 20 & Novo \\
\hline
\end{tabular}

Figura 1.1: Indice global de ecossistemas de startups. ${ }^{10}$

No entanto, ainda há muitos pontos a melhorar para consolidar permanentemente a comunidade paulistana e brasileira como um importante ecossistema empreendedor. Ainda há uma grande carência de iniciativas especificamente voltadas para a educação empreendedora, seja em possuir mais mecanismos que trabalhem com cursos e materiais especialmente voltados para esse fim, seja na difusão do empreendedorismo como opção de carreira. Outro ponto importante a ser trabalhado é a melhora das redes de networking,

\footnotetext{
${ }^{10}$ Adaptado de: COMPASS.CO. "The Global Startup Ecosystem Ranking 2015". The Startup Ecosystem Report Series, 2015.
} 
para integrar mais as pessoas já presentes no meio e atrair outras que estão interessadas em empreender ou trabalhar em startups, além de agregar conhecimento a ambos os lados.

Há também certas iniciativas nas quais a própria academia pode atuar para trazer uma melhora conjunta, como o baixo fator de inovação tecnológica presente no empreendedorismo brasileiro. Muitas startups brasileiras trabalham seus modelos de negócio em torno de lojas de comércio eletrônico, que raramente requerem algum tipo de inovação, ou de um modelo já existente (os chamados copycats). Um exemplo disso é a abundância de aplicativos de táxi presentes hoje nas lojas de aplicativos brasileiras, tais como Easy Taxi, 99Taxis, Taxibeat, dentre outros.

É papel fundamental das instituições acadêmicas incentivar não só a inovação tecnológica nas empresas, como também no próprio meio acadêmico, através de seu corpo docente e de seus pesquisadores. Uma aproximação maior da academia com as necessidades do mercado pode fazer com que as pesquisas acadêmicas realizadas na universidade cheguem mais facilmente a pessoas que podem transformá-las em negócios inovadores. Da mesma forma, o próprio mercado pode apresentar problemas reais que estudantes e pesquisadores podem analisar e solucionar, trazendo aos alunos uma maior aproximação com o futuro mercado de trabalho em que serão inseridos e, ao mesmo tempo, apresentando o empreendedorismo e a inovação como opções de carreira tão atrativas quanto as carreiras pública e particular.

Pretende-se aproveitar o bom momento do país em relação à cultura de inovação e o crescimento do ecossistema de startups para que São Paulo possa obter cada vez mais posições de destaque no ecossistema empreendedor global e atingir maiores níveis de maturidade como ecossistema empreendedor [CKK15b, CKK15a]. Também espera-se que, futuramente, este trabalho seja parte de um conjunto de iniciativas que visem unificar e fortalecer coletivamente todos os ecossistemas inovadores espalhados pelo Brasil, para que os empreendedores brasileiros possam aproveitar melhor as oportunidades únicas oferecidas pelo ecossistema nacional.

\subsection{Organização do trabalho}

Este trabalho está organizado da seguinte maneira: os conceitos fundamentais de empreendedorismo e ecossistemas de inovação são descritos no Capítulo 2. O Capítulo 3 refere-se à metodologia de pesquisa utilizada no levantamento e análise dos dados. Os resultados do estudo são apresentados no Capítulo 4. Finalmente, o Capítulo 5 apresenta as conclusões acerca dos capítulos anteriores e possíveis melhorias para o ecossistema. 


\section{Capítulo 2}

\section{Empreendedorismo e ecossistemas de inovação}

Este capítulo apresenta os principais conceitos para o entendimento deste trabalho, bem como uma revisão histórica do tema e sua importância no contexto econômico atual.

\subsection{Empreendedorismo e o empreendedor}

Apesar de o conceito de empreendedorismo já ser bem conhecido de maneira geral, não há uma definição exata para ele em termos acadêmicos, devido à sua proximidade com as diversas áreas do conhecimento envolvidas no seu estudo, tais como economia, administração e até mesmo antropologia [AS08]. O termo também já foi citado como sendo uma modalidade de administração [Rie11] e há grandes chances de que novos ramos de conhecimento sejam associados a ele nas próximas décadas.

Os primeiros registros históricos de uma definição formal do empreendedorismo datam aproximadamente de 1730, quando Richard Cantillon cita o indivíduo hoje conhecido por empreendedor como um portador de incerteza [AS08]. Os empreendedores são comumente categorizados com atributos como criatividade, capacidade de inovação e por sua habilidade como perceptores de oportunidades. No entanto, a definição formal como conhecemos hoje parte de Joseph Schumpeter, importante economista austríaco.

É importante ressaltar que apenas um aspecto da sua obra, o econômico, está sendo apresentado nesta dissertação. Isso se dá por ser o aspecto mais relevante para o tema dentre os inúmeros trabalhos do autor, que vão desde a administração até a ciência política.

Schumpeter coloca o "ato empreendedor" do "empresário empreendedor" como sendo a principal razão para o desenvolvimento econômico dentro do capitalismo [Sch10]. Ainda segundo ele, as inovações causam um "desequilíbrio" na estabilidade dos ciclos econômicos, fazendo com que antigas empresas, monopólios e mercados sejam destruídos para darem lugar a outros mais novos. Esse fenômeno foi posteriormente batizado como "destruição criativa". Alguns exemplos de inovações que ferem esse equilíbrio e forçam a evolução do mercado são: a introdução de um novo bem; a incorporação de um novo método de produção ou venda de bens existentes (novos mercados); a descoberta de uma nova fonte de matérias-primas; e a substituição de uma estrutura de mercado existente por outra nova (ex.: monopólio) [Sch34].

A Organização para o Desenvolvimento e Cooperação Econômica (The Organisation for Economic Co-operation and Development - OECD) define empreendedorismo em 3 partes [AH08]: o empreendedor, que é o indivíduo (dono de empresa) que busca gerar 
valor através da criação ou expansão da atividade econômica, pela identificação e exploração de novos produtos, processos ou mercados; a atividade empreendedora, que consiste na ação empresarial humana em busca da geração de valor, por meio da criação ou expansão da atividade econômica, pela identificação e exploração de novos produtos, processos ou mercados; e o empreendedorismo em si, que é o fenômeno associado à atividade empreendedora.

O empreendedor também pode ser descrito através da definição de "processo empreendedor", que envolve todas as funções, atividades e ações associadas à percepção de oportunidades e à criação de organizações para perseguir essas oportunidades. Sob esse ponto de vista, o empreendedor é o indivíduo que percebe uma oportunidade e cria uma organização para aproveitá-la [BH91].

Através da criação dessas organizações, surgem as empresas. Essas corporações sofreram profundas mudanças em seu modelo conceitual. A própria evolução da sociedade e os avanços da tecnologia forçam essas transformações; algumas empresas foram forçadas a adaptar seus modelos de negócio para não deixarem de existir. Outras não tiveram essa mesma visão a tempo - ou nem chegaram a ter esse vislumbre do futuro - e hoje só figuram em livros históricos e estudos de caso.

Com o impacto gerado pela internet e os negócios digitais, áreas como marketing, atendimento ao consumidor, logística, e até mesmo departamentos jurídicos e de recursos humanos foram forçados a repensar seus padrões para a nova realidade. Algumas negociações entre empresa, cliente e parceiros se dão em questão de minutos, e a variedade e a facilidade de acesso a novos produtos e serviços disponíveis ao consumidor é praticamente infinita. A tecnologia da informação facilita também a criação de novos modelos de negócios, com serviços e abordagens diferentes.

Um modelo de negócio é uma visualização concreta dos caminhos que a empresa deve trilhar e suas expectativas no trajeto. Teece [Tee10] explica que um modelo de negócios define informações sobre como uma determinada empresa cria e entrega valor a seus clientes, e transforma pagamentos recebidos por esse valor em lucro. Baden-Fullen e Morgan [BFM10] vão além, argumentando que, ao fazer a pergunta "O que é estratégia?", boa parte das pessoas dão uma resposta que inclui o termo "modelo de negócios". Para eles, além da abordagem tradicional, onde modelos de negócios servem para classificar empreendimentos, eles também podem atuar como instrumentos de pesquisa científica e como receitas a serem copiadas, podendo receber inovações e modificações.

Chesbrough [CR02, Che10], em parceria com Rosenbloom, descreve o modelo de negócios de uma forma mais prática, listando suas funções como sendo as seguintes:

- Articular a proposta de valor (value proposition), por exemplo, o valor criado aos usuários pela oferta baseada em tecnologia;

- Identificar um segmento de mercado, e especificar o(s) mecanismo(s) de geração de receita para a companhia;

- Definir a estrutura da cadeia de valor necessária dentro da firma para criar e distribuir o produto ou serviço, e determinar os ativos complementares necessários para apoiar a posição da firma nessa cadeia;

- Estimar a estrutura de custo e o potencial de lucro da produção, de acordo com o estabelecido na proposta de valor e na cadeia de valor;

- Descrever a posição da companhia na rede de valor, através da ligação entre fornecedores e consumidores, incluindo identificar e analisar possíveis parceiros e concorrentes; 
- Formular a estratégia competitiva pela qual a firma se colocará em posição de vantagem frente a seus competidores.

Osterwalder et al. [OPSM10] afirma que um modelo de negócios descreve a razão de como uma organização cria, entrega e captura valor. Seu conceito, aliado ao quadro (Canvas) descrita no livro "Inovação Em Modelos de Negócios" (Business Model Generation), busca trazer simplicidade, relevância e entendimento na elaboração de um modelo de negócios, facilitando a comunicação entre gerentes de diferentes partes da empresa. $\mathrm{O}$ quadro pode ser conferida na Figura 2.1.

\section{A tela de modelo de negócios}

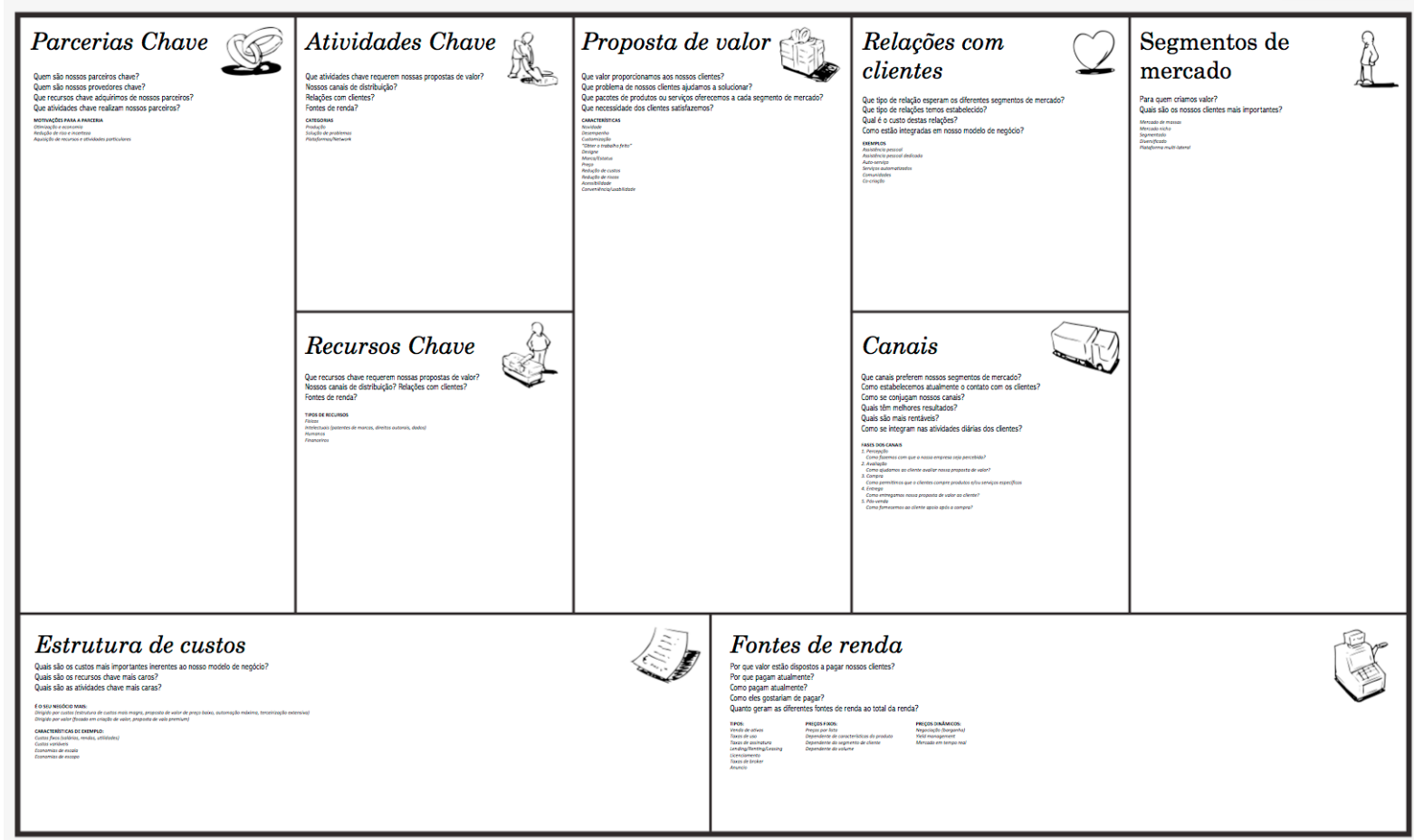

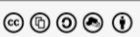

Figura 2.1: Quadro do modelo de negócio concebida por Osterwalder et al. ${ }^{1}$

O quadro é composta de nove painéis, cada um abordando um aspecto específico que deve ser trabalhado na criação de um negócio. Os blocos também acompanham algumas perguntas que podem ajudar na composição de cada item, e palavras-chave que variam de acordo com o foco de cada bloco, como tipos, exemplos, características, fases, etc.

Os painéis, listados em uma das possíveis ordens de preenchimento, são ${ }^{2}$ :

- Proposta de valor: consiste na característica principal do produto ou serviço. Ele deve agregar valor para o cliente, sanar um possível problema (ou uma "dor") que o usuário possua, ou atender a uma necessidade, pré-existente ou não;

- Segmentos de mercado: trata dos segmentos de clientes que serão atendidos pela solução;

\footnotetext{
${ }^{1}$ Adaptado de: http://viversemchefe.com/business-model-canvas-em-portugues/, último acesso em $27 / 10 / 2015$.

${ }^{2}$ Adaptado de: http://www.sebraepr.com.br/sites/PortalSebrae/artigos/Canvas: -como-estruturar-seu-modelo-de-neg\%C3\%B3cio, último acesso em 27/10/2015.
} 
- Canais: aborda a maneira na qual o cliente receberá o produto;

- Relacionamento com clientes: retrata de que forma o cliente e a empresa estarão em contato em etapas como manutenção e pós-venda;

- Atividade chave: aqui são listadas as atividades necessárias para poder entregar ao cliente a proposta de valor. Ex.: produção de uma determinada plataforma, divulgação, etc.

- Recursos chave: similar ao item anterior, mas voltado para os recursos que a proposta de valor exige, sejam físicos, humanos, financeiros ou intelectuais;

- Parcerias chave: também pode estar relacionado aos dois itens anteriores. Refere-se aos recursos ou atividades que podem ser providos por terceiros para a entrega da proposta de valor;

- Fontes de renda: consiste na receita gerada através da propostas de valor. Uma pergunta que pode resumir o bloco é: "Quanto meus clientes estão dispostos a pagar por esse valor?";

- Estrutura de custos: reúne os custos de todos os itens que formam a proposta de valor.

Através do preenchimento de cada bloco, espera-se que o empreendedor tenha uma visão integral de todos os elementos do seu negócio, e que possa questionar-se acerca da rentabilidade ou não de seu modelo, consertando possíveis falhas durante a vida de seu produto. Recomenda-se ter um canvas para cada produto ou cliente.

A importância do modelo de negócios vai além da mera estratégia. O modelo de negócios é o caminho para chegar ao lucro. Se o gestor não conseguir encontrar um modelo de negócios que capture o real valor da tecnologia, será gerado para a empresa menos valor do que deveria. Esse pode ser um erro crítico para empresas e fatal para startups [Che10].

O empreendedorismo, em particular a ação empreendedora, tem acompanhado a humanidade desde tempos primórdios. No entanto, a partir do final do Século 20, pequenas empresas de tecnologia formadas por poucas pessoas ou até mesmo fundadas em garagens, tais como Apple e Microsoft, começaram a despontar no cenário empreendedor. Várias dessas empresas alcançaram a posição de gigantes mundiais em poucas décadas. Isso ocasionou um grande crescimento no número dessas empresas, que começaram a ser chamadas de startups, especialmente na virada do século.

O surgimento das startups teve seu ápice em meados de 2010, onde dezenas de centros mundiais de criação de startups começaram a surgir. Esses centros, que concentram cada um centenas ou milhares de startups, começaram a ser chamados de ecossistemas de startups, devido à alta concentração de elementos favoráveis ao surgimento dessas empresas. Tais elementos serão detalhados nos próximos capítulos.

\subsection{Startups}

Apesar do verbete "start-up" ser definido no dicionário Oxford como "um negócio recém-estabelecido" ${ }^{3}$, o conceito prático da palavra vai muito além disso.

\footnotetext{
${ }^{3}$ http://www.oxforddictionaries.com/us/definition/american_english/start-up?q=startup, último acesso em $26 / 08 / 2015$.
} 
Steve Blank, professor de empreendedorismo de universidades como Universidade da Califórnia em Berkeley, Universidade de Stanford, Universidade de Columbia, NYU (Universidade de Nova Iorque) e UCSF (Universidade da Califórnia em São Francisco) e empreendedor do Vale do Silício; e Bob Dorf, que se auto-define como um "empreendedor em série aposentado", são os criadores da metodologia Customer Development (Desenvolvimento do Cliente).

Em sua obra, startups são definidas como organizações temporárias em busca de um modelo de negócios repetível e escalável [BD12]. Nesse caso, a temporariedade de uma instituição assim parte de uma regra simples: ela deve almejar ser "promovida" a empresa o mais rápido possível (encontrando seu modelo de negócios repetível e escalável), ou perceber a insustentabilidade do mesmo e fechar as portas sem maiores prejuízos financeiros e consumo de tempo por parte de seus colaboradores.

Uma definição semelhante parte de Eric Ries, famoso empreendedor do Vale do Silício e idealizador do Lean Startup (A Startup Enxuta), que descreve esse tipo de empresa como uma instituição humana projetada para criar novos produtos e serviços sob condições de extrema incerteza [Rie11].

Como não há um conceito fechado sobre o termo, definições informais sobre startups, dadas por importantes membros do ecossistema, também são encontradas facilmente pela internet. Uma das mais populares é a do fundador da aceleradora e fundo de investimento 500 Startups, Dave McClure, que explica na rede social de perguntas e respostas Quora que uma startup é "uma empresa confusa sobre qual é o produto, quem são os clientes e como fazer dinheiro" 4 . Segundo ele, assim que a empresa consegue responder a essas três perguntas, ela já não é uma startup.

Já Paul Graham, programador Lisp e um dos fundadores da Y Combinator (aceleradora estadunidense de investimento de capital semente), descreve uma startup como sendo uma empresa projetada para crescer rapidamente ${ }^{5}$, não importando se a empresa tem foco tecnológico ou se recebe aportes financeiros. Ele destaca ainda que a própria existência de uma termo próprio já mostra que há uma diferença entre startups e empresas pequenas.

É importante ressaltar que tratar esses dois tipos de empreendimento como sendo iguais é um erro muito comum. As startups, sua concepção, seu modelo de negócio e execução e até o contexto e as regras a que estão submetidas são totalmente diferentes de empresas tradicionais, posto que essas empresas não atuam nas mesmas condições de incerteza em que as startups se baseiam. Enquanto empresas tradicionais geralmente já possuem um modelo de negócios validado, startups estão na busca por esse modelo, ou por descobrir que ele não existe o mais rápido possível - e assim seguir em frente, sem perda de tempo [BD12].

Sutton [Sut00] define as seguintes características como sendo características recorrentes em startups:

- Pouca experiência acumulada ou história: segundo o autor, esta é uma das características mais básicas de uma startup. Elas geralmente são novas, ou pelo menos mais novas e menos experientes que outras corporações. Essa imaturidade pode atingir tanto a nível de processo quanto na organização.

- Limitação de recursos: além da limitação, os recursos disponíveis geralmente são aplicados em atividades de "externalização", tais como divulgar o produto e construir

\footnotetext{
${ }^{4}$ http://www.quora.com/What-is-the-proper-definition-of-a-startup/answer/Dave-McClure, último acesso em 26/08/2015.

${ }^{5}$ http://www.paulgraham.com/growth.html, último acesso em 26/08/2015.
} 
alianças estratégicas.

- Múltipla influência: comparadas a outras empresas, startups em estágios iniciais sofrem mais influência de fatores internos e externos, tais como investidores, clientes e concorrentes, o que obriga a empresa a se reajustar frequentemente.

- Tecnologias e mercados dinâmicos: novas empresas geralmente tendem a desenvolver ou a trabalhar com novas tecnologias para poder se colocar em um mercado com maior possibilidades de retorno.

Apesar de estas características poderem ser relacionadas também a grandes empresas, startups seguem essas regras muito mais intensamente. Essas similaridades também podem ser estendidas a pequenas empresas, mas essas corporações apresentam vantagens exclusivas em detrimento das startups, tais como menos problemas de comunicação e coordenação internas, maior flexibilidade, uma base já consolidada de produtos e parceiros e um histórico compartilhado. As franquias são um exemplo comum dos dois últimos itens relacionados.

\subsubsection{Ciclos de vida}

Não há uma visão de consenso sobre qual é o ciclo de vida de uma startup. No entanto, há algumas formas comuns usadas para descrevê-lo usadas pelo mercado, dependendo do ponto de vista mais interessante ao observador ${ }^{6}$.

O primeiro deles, o Ciclo do Desenvolvimento do Cliente, não é necessariamente o ciclo de vida de uma startup, e sim o ciclo de vida da metodologia criada por Steve Blank [BD12]. No entanto, muitos empreendedores usam as etapas para descrever o ciclo de vida de startups.

As fases estão entrelaçadas com o modelo de descoberta e validação do cliente proposto pelo autor. São elas:

- Descoberta (Customer Discovery): O objetivo desse período é entender se as hipóteses formuladas estão corretas e se a solução está atacando um problema relevante. Nessa fase, os fundadores da startup devem "sair do prédio" para validar hipóteses sobre o problema e a solução, para modelar seus diferenciais e descobrir seus clientes em potencial.

- Validação (Customer Validation): Após descobrir quem são os clientes, iniciase a venda, esperando-se chegar num modelo de vendas repetível que venha a se tornar algo concreto para as equipes de venda e marketing. Ajustes nessa fase são fundamentais. Buscar pessoas que gostem do seu produto, que estejam dispostas a testá-lo e a difundi-lo para amigos e pessoas próximas (os chamados early adopters) é uma tarefa crítica nesse momento, pois essas pessoas podem fornecer informações vitais sobre como o produto pode ser ajustado para melhor se adequar às suas necessidades.

- Criação do Cliente (Customer Creation): Essa etapa é voltada para trazer massivamente os clientes para a startup e fidelizá-los. Investimentos pesados em marketing são uma das atividades-chave para esse momento. O objetivo é consolidar o sucesso feito na etapa anterior.

\footnotetext{
${ }^{6}$ http://www.techinasia.com/startup-stages, último acesso em 09/09/2015.
} 
- Construção da Empresa (Company Building): Steve Blank define essa fase como a "formatura" da startup, que já pode ser considerada uma companhia por ter encontrado seu modelo de negócios repetível e escalável. Há uma formalização dos departamentos, que antes eram voltados à descoberta, e a partir de agora terão suas próprias missões.

O próprio Blank descreve as fases de uma maneira mais simplificada. Em uma publicação em seu blog pessoal", o autor divide as etapas acima em três "passos" (Figura 2.2): a busca, correspondente às duas primeiras fases listadas acima, onde o foco da startup é buscar seu "modelo de negócios repetível e escalável"; e a construção, constituída pelas duas últimas, onde a empresa precisa escalar de uma maneira que mantenha o fluxo de caixa positivo e/ou consiga usuários em uma frequência que possa ser monetizada. Essa divisão também aparece em sua obra de apresentação da metodologia de Desenvolvimento do Cliente [BD12]. A última fase, que não está diretamente relacionada com essa metodologia, é a de crescimento, onde a companhia já apresenta liquidez.

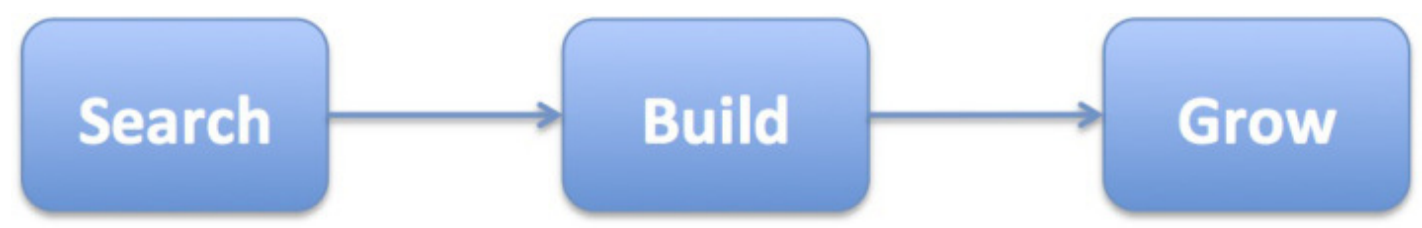

Figura 2.2: Ciclo de vida de uma startup apresentado por Steve Blank. ${ }^{8}$

Outro ciclo de vida, baseado livremente no Ciclo do Desenvolvimento do Cliente, é o ciclo Marmer. Seu nome provém de Max Marmer, fundador da Compass (antigo Startup Genome), um arcabouço que visa descobrir, através da análise de dados, os motivos que levam uma startup a ter ou não sucesso ${ }^{9}$. O Ciclo Marmer oferece uma perspectiva mais focada no produto, ao contrário do processo de criação e gestão apontado por Blank, e foi baseado em dados fornecidos por milhares de startups ao redor do mundo.

As 4 etapas fundamentais do ciclo são ${ }^{10}{ }^{11}$ :

- Descoberta: Similar ao Customer Development, essa fase requer a validação de que o problema a ser resolvido é importante e de que a solução atrai o interesse das pessoas. Algumas atividades importantes dessa etapa são construir o time de fundadores, conduzir entrevistas com clientes, encontrar a proposta de valor e criar os primeiros MVPs (uma amostra mínima do produto que demonstre ao máximo a funcionalidade mais importante do produto). Também pode ocorrer nesse período a entrada do time em uma incubadora ou sua participação num processo de aceleração e/ou o surgimento dos primeiros mentores e conselheiros que irão ajudar a equipe nessa empreitada.

- Validação: O objetivo dessa etapa é garantir que as pessoas estão interessadas no produto, fazendo-as oferecer dinheiro ou atenção por isso. Os primeiros clientes pagantes devem aparecer nessa fase, e ajustes no produto ou até pivotagens (mudanças de estratégia que afetam o plano de negócios) são passos fundamentais para garantir a continuidade da startup no ciclo.

\footnotetext{
${ }^{7}$ http://steveblank.com/2015/02/12/what-do-i-do-now/, último acesso em 09/09/2015.

${ }^{8}$ Extraído de: http://steveblank.com/2015/02/12/what-do-i-do-now/, último acesso em 19/10/2015.

${ }^{9}$ http://blog.startupcompass.co/42010809, último acesso em 09/09/2015.

${ }^{10}$ http://www.techinasia.com/startup-stages, último acesso em 09/09/2015.

${ }^{11}$ http://blog.startupcompass.co/pages/marmer-stages, último acesso em 09/09/2015.
} 
- Eficiência: Aqui a empresa deve confirmar a eficácia do seu modo de aquisição de clientes. É uma etapa importante para evitar que a empresa cresça descontroladamente, endividando-se, por exemplo. A proposta de valor é ainda mais refinada, e canais de venda e aquisição de clientes devem ser postos à prova para garantir sua repetibilidade.

- Escala: Com as bases de crescimento e aquisição de clientes consolidadas, a companhia deve se firmar e iniciar um crescimento ainda mais agressivo. Nessa etapa, consolidam-se os departamentos e geralmente são feitas contratações de funcionários executivos.

Há ainda duas outras etapas, a de Sustento e a de Conservação, mas elas não são detalhadas. Espera-se que essas etapas sejam estudadas e detalhadas em artigos posteriores dos idealizadores do ciclo.

Várias outras variações desses modelos podem ser encontradas facilmente pela internet. Em geral, pode-se dizer que muitos membros importantes do ecossistema dão sua opinião sobre o assunto através de blog e páginas pessoais. A Figura 2.3, por exemplo, apresenta um modelo de ciclo de vida de autoria desconhecida apresentado por Thomas Schranz, CEO (diretor executivo) da Blossom (uma plataforma de gerenciamento de projetos ágeis) em seu blog. Nesse caso, a única diferença é o "chasm" (abismo): a distância entre os early adopters e uma base de usuários fiel, que segundo especialistas, têm diferentes expectativas em relação ao produto [Moo99].

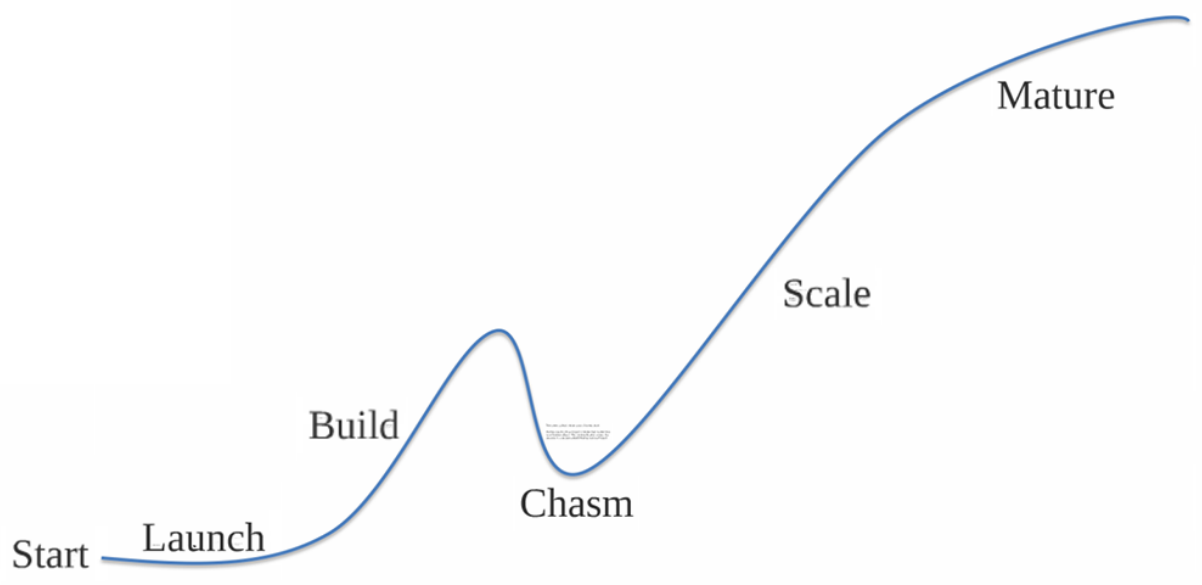

Figura 2.3: Ciclo de vida de uma startup apresentado por Thomas Schranz. ${ }^{12}$

Outros autores também apresentam conceitos semelhantes, mas a maioria deles acaba convergindo ou se assemelhando às etapas descritas por Steve Blank.

Em geral, startups têm uma forte ligação com a tecnologia, seja como ferramenta (facilitando a criação de protótipos ou viabilizando a implantação ou expansão das operações), seja como parte fundamental do negócio. A proximidade das startups com a tecnologia é o que força a evolução de ambos - tanto na criação de novos recursos, quanto na forma como esses recursos são utilizados. Startups tecnológicas conduzem naturalmente a uma

\footnotetext{
${ }^{12}$ Extraído de: https://www.blossom.co/blog/lifecycle-of-a-startup, último acesso em 09/09/2015.
} 
evolução da tecnologia, que no Século 21 desponta como um item crítico para a economia: a inovação.

\subsection{Inovação}

Inovação pode ser definida, de maneira ampla, como a concepção, criação e implementação de novos produtos e processos ou mudanças em produtos e processos existentes que agregam valor à sociedade [Avi11]. Melhorias e a apresentação de soluções também podem ser vistas como inovação. No entanto, é consensual que apenas implementações contam como inovação, por trazerem um impacto real e visível [DP13]. Para Chesbrough, há uma diferença notável entre invenção e inovação, onde inovação refere-se a uma invenção implementada e levada para o mercado [Che03]. Normalmente a inovação é tratada como representante de um impacto positivo para o meio em que atua [DP13].

Uma outra visão trata a inovação como a decisão de aceitar a absorção de um determinado conhecimento, por exemplo, o tecnológico, bem como avaliar modificações ou melhorias que possam ser aplicadas a produtos e processos [Bar95]. Em um sentido econômico, inovação é a aplicação de novas formas de geração de valor ou de conhecimento na economia [MC08].

A inovação hoje é fundamental em qualquer setor de mercado. Inovar acelera a geração de valor e traz equilíbrio para corporações e para países, por manter a justa concorrência e promover o surgimento de novos negócios. Além disso, inovações com base científica resultam em produtos baseados em propriedade intelectual, que motivam a competição por mais domínio de mercado, e podem até mesmo resultar em posições de monopólio momentâneas [MC08].

Nesse contexto, mais do que uma ferramenta, a inovação torna-se quase uma necessidade do empreendedor não-tradicional. A descoberta de um modelo de negócios repetível e escalável normalmente implica em caminhos pouco ortodoxos, muita vezes não explorados, ou até mesmo inexistentes. E apesar de grandes empresas, em geral, gerarem processos de inovação mais significativos do que empresas menores [DGDS11], empresas menores têm um papel importantíssimo na geração de inovação.

É bastante raro que a inovação apareça de maneira independente. Em geral, ela é fruto de um aprimoramento ou questionamento de um conhecimento ou técnica prévia, ou utiliza produtos já consolidados como base para o desenvolvimento de novos. Além disso, a inovação em um determinado artigo pode adaptar uma inovação já feita em subcomponentes que fazem parte de sua constituição, ou forçar a inovação em componentes externos.

Por muito tempo, a inovação foi focada apenas internamente, ou seja, as empresas atuavam pensando unicamente em evoluir seus produtos e lançá-los ao mercado. No entanto, a dificuldade tecnológica sempre crescente praticamente obriga essas empresas hoje a buscar conhecimento externo para dar prosseguimento ao processo inovativo [dA13]. Este modelo foi denominado por Chesbrough como Inovação Aberta [Che03]. Essa cooperação, não só entre empresas, mas também entre centros de pesquisa externos, acelera o processo inovativo, diminuindo o tempo de criação de novos produtos e torna a economia mais dinâmica [dA13], bem como auxilia na padronização do consumo e da produção [DGDS11].

A informação é um item crítico na produção de inovação e no processo de melhoria [DP90]. A cada vez maior cooperação entre entidades de pesquisa e corporativas, aliada a fatores regionais, tais como a infraestrutura de transporte e o acúmulo de várias atividades 
[Kar08b], dá origem a uma rede complexa de informação, difusão do conhecimento e inovação.

\subsection{Ecossistemas de inovação e aglomerados industriais}

Empresas, universidades, institutos de pesquisa, organizações trabalhistas e empresariais e órgãos governamentais responsáveis por planejar ou financiar atividades de pesquisa e desenvolvimento são algumas das principais entidades produtoras ou fomentadoras de inovação. A interrelação entre essas unidades, suas formas de cooperação e a profundidade de suas ligações se tornaram importantes para a economia de inovação, produzindo mudanças marcantes em vários países. Assim, pesquisadores da área desenvolveram o conceito de Sistemas Nacionais de Inovação, a partir da correlação entre esses agentes e seu impacto em determinada nação [DGDS11] [dA13]. No Brasil, o principal recurso de geração de conhecimento desse ecossistema vem através das universidades, especialmente as públicas, com seus cursos de pós-graduação altamente competitivos e com alto número de formação de profissionais [DGDS11].

Schumpeter afirma que inovações trazem o progresso para atividades específicas, gerando ciclos econômicos que acabam por se desdobrar não só naquela atividade econômica em si, mas na economia de um modo geral, por meio de clusters [DGDS11]. Estes clusters, que podem ser traduzidos livremente como aglomerados industriais ou empresariais, surgem da tendência de indústrias e atividades comerciais de se agrupar em locais próximos, para obter certos benefícios [Kar08a].

Dentre as principais vantagens obtidas pela concentração, estão:

- A facilidade de contato informal entre os membros, facilitando a troca de conhecimento, importantíssima para mercados com constante mudança, tais como o tecnológico;

- A entrada de certos "insumos especializados" se torna mais fácil e é difundida mais rapidamente do que aconteceria em uma região de dispersão geográfica maior.

- A região facilita a criação de um mercado de trabalho concentrado com mão-de-obra especializada e facilidade de acesso a esses recursos humanos.

Uma das desvantagens comuns nesse tipo de distribuição é a possível diminuição de lucro pela alta proximidade de concorrentes. No entanto, para startups, especialmente as tecnológicas, isso não é um problema, por serem negócios predominantemente virtuais e, portanto, a localização física impacta pouco para a escolha do cliente. E mesmo para empresas tradicionais, as vantagens da proximidade superam esse inconveniente.

Na biologia, um ecossistema é caracterizado pela interação entre os seres vivos e o ambiente em que se encontram de maneira harmônica. De uma maneira similar, um ecossistema de inovação é aquele em que a produção de conhecimento e a transformação desse conhecimento em novos produtos caminham juntas, trazendo equilíbrio e incentivando uma à outra.

Segundo Shlomo Maital, professor emérito de Technion, em Israel, os ecossistemas de inovação de cada país são, ao mesmo tempo, iguais, parecidos e diferentes uns dos outros, no sentido de que cada um tem suas semelhanças em suas pessoas, seus agentes e seus modos de execução, mas concomitantemente cada um desses fatores tem peculiaridades que se misturam às raízes de determinada nação [MF14]. 
Em tecnologia, um ecossistema de startups pode ser definido como o conjunto de pessoas, startups e organizações de fomento, situados em um mesmo local e interagindo na forma de um sistema voltado para a geração de novas startups. Alguns atores comuns dentro de ecossistemas de startups serão apresentados e discutidos mais profundamente na Seção 4.1.

Um conceito relativamente similar a esse é o de centros de tecnologia, ou de centros de startups, mas eles são vistos mais comumente em nível local ou regional, enquanto um ecossistema de inovação pode impactar toda a economia global [DP13].

\subsection{São Paulo como ecossistema empreendedor}

A cidade de São Paulo tem obtido posições de destaque em índices de avaliação de ecossistemas empreendedores nacionais e internacionais. Segundo a Endeavor, uma organização de fomento a negócios de alto impacto, São Paulo é a segunda melhor cidade empreendedora do Brasil [End14], ficando atrás somente de Florianópolis, muitas vezes por quesitos comuns em cidades grandes que ora podem favorecer, ora atrapalhar o empreendedor. O resultado do estudo pode ser visto na Figura 2.4.

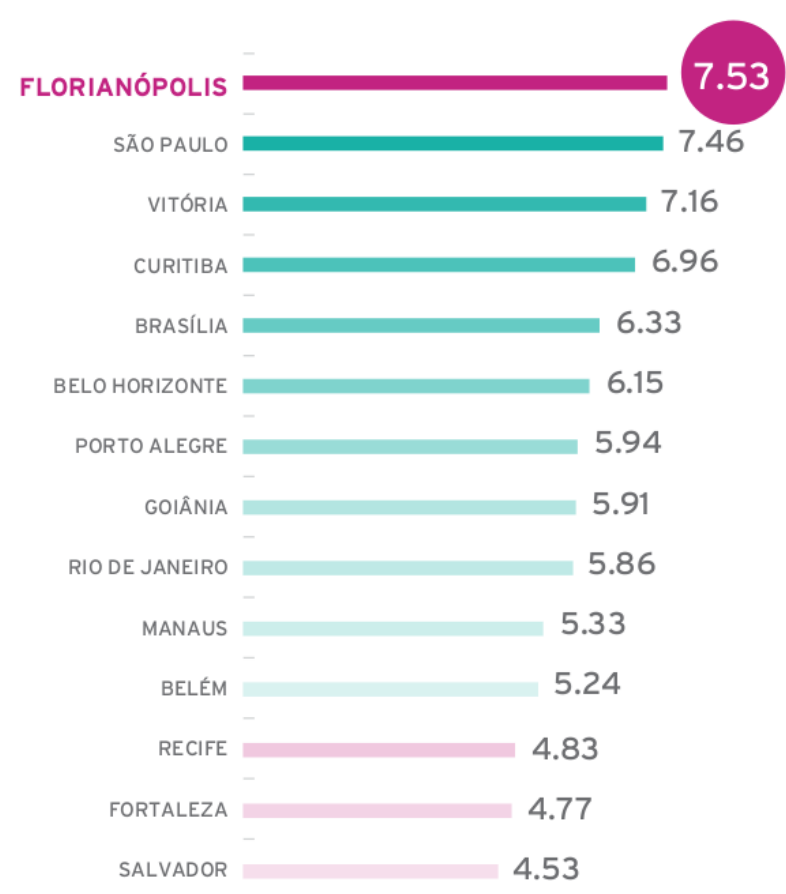

Figura 2.4: Índice de Cidades Empreendedoras Endeavor. ${ }^{13}$

As duas líderes do índice são capitais importantes do Brasil, mas totalmente diferentes em termos de escala. São Paulo é a sétima cidade mais populosa do globo, possuindo mais de 11 milhões de habitantes - mais de vinte e cinco vezes a população de Florianópolis, que em 2010 possuía pouco mais de 420.000 habitantes $^{14}$. São Paulo se destaca também por ter o terceiro maior PIB (Produto Interno Bruto) do Brasil, com valor de mais de 47 bilhões, atrás apenas do PIB nacional e o do estado de São Paulo.

Enquanto isso, a capital de Santa Catarina ficou em $51^{\circ}$ lugar, com aproximadamente 11 bilhões [IBG13]. É o menor PIB das 14 cidades estudadas pela Endeavor. Não se sabe

\footnotetext{
${ }^{13}$ Extraído de: Endeavor. "Índice de Cidades Empreendedoras Brasil 2014”. Disponível em: http://info. endeavor.org.br/ice2014, último acesso em 11/09/2015.

${ }^{14}$ Dados extraídos de: http://cidades.ibge.gov.br/xtras/home.php, último acesso em 19/10/2015.
} 
a quantidade exata de startups instaladas em Florianópolis, mas a cidade conta com 600 empresas do setor de tecnologia ${ }^{15}$.

\begin{tabular}{|c|c|c|c|c|c|c|c|c|}
\hline & Ranking & & Performance & Funding & Market Reach & Talent & Startup Exp. & Growth Index \\
\hline Silicon Valley & 1 & 4 & 1 & 1 & 4 & 1 & 1 & 2.1 \\
\hline New York City & 2 & -3 & 2 & 2 & 1 & 9 & 4 & 1.8 \\
\hline Los Angeles & 3 & 4 & 4 & 4 & 2 & 10 & 5 & 1.8 \\
\hline Boston & 4 & -2 & 3 & 3 & 7 & 12 & 7 & 2.7 \\
\hline Tel Aviv & 5 & $\cdot 3$ & 6 & 5 & 13 & 3 & 6 & 2.9 \\
\hline London & 6 & -1 & 5 & 10 & 3 & 7 & 13 & 3.3 \\
\hline Chicago & 7 & -3 & 8 & 12 & 5 & 11 & 14 & 2.8 \\
\hline Seattle & 8 & $\cdot 4$ & 12 & 11 & 12 & 4 & 3 & 2.1 \\
\hline Berlin & 9 & -6 & 7 & 8 & 19 & 8 & 8 & 10 \\
\hline Singapore & 10 & -7 & 11 & 9 & 9 & 20 & 9 & 1.9 \\
\hline Paris & 11 & 4 & 13 & 13 & 6 & 16 & 15 & 1.3 \\
\hline Sao Paulo & 12 & - 1 & 9 & 7 & 11 & 19 & 19 & 3.5 \\
\hline Moscow & 13 & -1 & 17 & 15 & 8 & 2 & 20 & 1.0 \\
\hline Austin & 14 & NEW & 16 & 14 & 18 & 5 & 2 & 1.9 \\
\hline Bangalore & 15 & -4 & 10 & 6 & 20 & 17 & 12 & 4.9 \\
\hline Sydney & 16 & -4 & 20 & 16 & 17 & 6 & 10 & 1.1 \\
\hline Toronto & 17 & .9 & 14 & 18 & 14 & 15 & 18 & 1.3 \\
\hline Vancouver & 18 & -9 & 18 & 19 & 15 & 14 & 11 & 1.2 \\
\hline Amsterdam & 19 & NEW & 15 & 20 & 10 & 18 & 16 & 3.0 \\
\hline Montreal & 20 & NEW & 19 & 17 & 16 & 13 & 17 & 1.5 \\
\hline
\end{tabular}

Figura 2.5: Ranking global de ecossistemas de startups. ${ }^{16}$

São Paulo também é atualmente o ecossistema de maior destaque da América Latina, segundo o último levantamento sobre regiões empreendedoras realizado pela Compass, um arcabouço de dados de startups anteriormente conhecido como Startup Genome. O índice, que pode ser conferido na Figura 2.5, consiste dos seguintes quesitos:

- Performance: consiste no desempenho de fundos e vendas de startups.

- Funding: o tempo necessário para um fundo levantar investimento.

- Market reach: o alcance de mercado.

- Talent: capital humano, seu custo e sua qualidade.

- Startup experience: os "fatores de experiência" que agregam valor às startups de cada ecossistema.

- Growth index: a porcentagem de crescimento em comparação com outras regiões.

No ano de 2015, São Paulo aparece em $12^{\circ}$ lugar, tendo subido uma posição em relação ao último estudo, realizado em 2012. A comparação direta entre as tabelas de 2012 e 2015

\footnotetext{
${ }^{15}$ http://blogs.estadao.com.br/link/florianopolis-busca-reconhecimento-como-polo-de-inovacao-e-startups/, último acesso em 19/10/2015.
} 
da Compass se torna difícil devido a mudanças na maioria dos critérios de avaliação da instituição, que foram reduzidos de 8 para 5 entre uma edição e outra. Outros itens, como o índice de diferença em relação ao Vale do Silício, foram removidos. No entanto, a maioria dos indicadores da cidade obteve melhorias ou se manteve estável entre as duas edições.

São Paulo se destaca por ser a única representante da América Latina nas primeiras 20 posições, e ter o terceiro maior índice de crescimento no ranking (3,5\%), superado apenas por Berlim (10\%) e Bangalore (4,9\%). A cidade também possui a melhor média sul-americana no quesito talentos. Segundo o estudo, casos de sucesso como Dafiti e Netshoes são responsáveis por mais pessoas buscando o empreendedorismo como opção de carreira, mas a proporção de empregados de startup com experiências anteriores nesse tipo de negócio é $42 \%$ menor em comparação ao Vale do Silício.

Em termos de financiamento, mais de $85 \%$ das rodadas de investimento realizadas no ecossistema contam apenas com investidores locais, apesar da presença de fundos importantes do Vale do Silício como 500 Startups e Redpoint e.ventures. O investimento médio por startup na cidade é metade do investimento que ocorre no Vale do Silício. São Paulo tem um bom índice no quesito mercado devido ao tamanho do mercado local, mas ter apenas $18 \%$ de clientes fora do país faz com que a cidade ocupe o último lugar no quesito alcance de mercado global (não presente na tabela).

São Paulo também tem feito importantes investimentos em relação à inovação. Além da criação de novos parques tecnológicos na capital e no interior do estado, os investimentos em pesquisa e desenvolvimento tiveram 53\% de crescimento em 10 anos, descontada a inflação, segundo relatório da FAPESP [FAP14].

Tanto o reconhecimento do ecossistema de São Paulo quanto o aumento de investimentos e políticas públicas na região são fatores que justificam a escolha desse dentre outros ecossistemas para a realização do estudo. Adicionalmente, considera-se fundamental a análise profunda do ecossistema em um momento tão crítico, onde os esforços de múltiplas instituições de impacto estão sendo redobrados para aprimorar a qualidade do meio.

Os próximos capítulos darão início à apresentação do estudo, explicando sua metodologia e apresentando posteriormente os resultados obtidos.

\footnotetext{
${ }^{16}$ Extraído de: COMPASS.CO. "The Global Startup Ecosystem Ranking 2015". The Startup Ecosystem Report Series, 2015.
} 


\section{Capítulo 3}

\section{Metodologia}

Nas seções seguintes, apresenta-se a concepção da metodologia de pesquisa e os procedimentos para coleta, processamento e análise dos dados.

\subsection{Construção da pesquisa}

A metodologia escolhida para a coleta de dados deste trabalho foi a pesquisa qualitativa, que pode ser descrita como uma técnica elaborada para explorar um determinado assunto através de seu lado humano, por meio das visões e experiências individuais de cada um [Giv08]. De uma maneira simplificada, podemos descrever a diferença entre pesquisa quantitativa de qualitativa como esta última sendo orientada a "variáveis que não podem ser medidas, apenas observadas" [Wai07].

A grande importância dos dados desta pesquisa está nas pessoas (players) que atuam nesse ecossistema e sua visão única e diferenciada desse ambiente e da sua atuação nele. Como as informações coletadas tem um caráter pessoal e único, uma avaliação quantitativa se torna menos apropriada.

A pesquisa realizada também contém elementos de Teoria Fundamentada em Dados (Grounded Theory) [CS14]. A Teoria Fundamentada em Dados é uma metodologia de campo que, a partir de uma série de dados, oferece mecanismos para a construção de novas hipóteses acerca de um determinado tema, num processo quase reverso a outras metodologias de pesquisa [CCP96].

Ao contrário de outras metodologias de pesquisa, não se iniciou o estudo com uma teoria que seria testada, e sim com hipóteses que seriam validadas ou descartadas ao longo do tempo. Além disso, os tópicos das perguntas de pesquisa que norteiam o estudo são diretrizes que devem ser levadas em consideração, e não regras que devem ser seguidas à risca, o que exige uma flexibilidade que pesquisas quantitativas normalmente não apresentam.

Neste trabalho, pretende-se ilustrar quais são as características marcantes do ecossistema de startups de software da cidade de São Paulo, através de um mapa conceitual, para facilitar as comparações com outros ecossistemas de alto impacto.

Esta pesquisa foi dividida em 3 etapas:

1. Entrevistas e observações

2. Codificação dos dados

3. Análise e conclusões 


\subsection{Entrevistas}

Entrevistas são uma estratégia comum para a coleta de dados qualitativos, por ser um recurso eficaz para descobrir as experiências e percepções dos participantes acerca da área de estudo [Giv08].

Para as entrevistas, foi concebida uma sequência de perguntas, elaboradas de comum acordo pelo grupo de pesquisa em empreendedorismo ${ }^{1}$ do IME-USP e que representam uma extensão das perguntas de pesquisa usadas em um trabalho anterior do grupo [KCHY14]. A metodologia desenvolvida neste trabalho gira em torno da criação de um arcabouço conceitual a partir do mapeamento de fatores-chave para o surgimento de ecossistemas de startups de sucesso.

A semelhança entre esses dois trabalhos é proposital, para permitir futuras comparações entre ambos com maior facilidade e possibilitar, se for o caso, a expansão do mesmo para outras cidades ou regiões, ou até mesmo a evolução para um modelo padronizado.

Em geral, cada pergunta de pesquisa do estudo deu origem a duas ou três perguntas da entrevista. As questões de pesquisa usadas como base para as perguntas são:

- QP1 - Quais são as características socioculturais de São Paulo que fomentam o espírito empreendedor?

- QP2 - Quais são os mecanismos institucionais em São Paulo que promovem ou dificultam o empreendedorismo?

- QP3 - Quais são os mecanismos educacionais em São Paulo que promovem ou dificultam o empreendedorismo?

- QP4 - Quais são as características de times inovadores e empreendedores de sucesso? Qual é a principal motivação do empreendedor de software?

- QP5 - Quais aspectos tecnológicos influenciam o sucesso das startups de software, e como? Em particular, qual é o papel executado por Orientação a Objetos, linguagens, arcabouços, padrões, modelos e arquiteturas? Qual é o papel do Software Livre?

- QP6 - Quais aspectos metodológicos influenciam o sucesso das startups de software, e como? Qual é o nível de adoção de métodos de desenvolvimento de negócios e de software bem conhecidos? Essa relação muda de acordo com o ciclo de vida da startup?

A meta foi entrevistar entre 4 e 5 dezenas de pessoas envolvidas de maneira direta com o ecossistema de startups de São Paulo. Essas pessoas deveriam possuir diferentes papéis dentro do ecossistema. A Tabela 3.1 mostra a quantidade de entrevistados distribuídos entre seus respectivos papéis.

O número de entrevistados foi definido a partir do trabalho inicial do grupo de pesquisa realizado em Israel. A estimativa mais recente sobre o número de startups na cidade de São Paulo é a informação de 2015 do Ranking Global de Startups, que afirma que atualmente encontram-se na capital entre 1.500 e 2.700 startups de tecnologia ativas [Com15].

Quarenta entrevistas foram conduzidas de forma presencial, majoritariamente nas próprias startups ou em lugares neutros próximos a elas. O objetivo dessa abordagem era tornar o contato com os entrevistados mais pessoal, facilitando a interação, bem como

\footnotetext{
${ }^{1}$ http://ccsl.ime.usp.br/startups
} 


\begin{tabular}{lllllr}
\hline Aceleradoras & Governo & Investidor Anjo & Startup & VC & Total \\
\hline 3 & 1 & 1 & 32 & 4 & $\mathbf{4 1}$ \\
\hline
\end{tabular}

Tabela 3.1: Distribuição de entrevistados e seus papeis no ecossistema.

conhecer um pouco o ambiente de trabalho de cada startup. Além disso, entrevistas presenciais ajudam a obter informações não-verbais importantes, como gestos e acenos que seriam imperceptíveis em entrevistas à distância e o próprio ambiente no qual a startup está situada [Giv08]. Em apenas um caso, a entrevista foi realizada por Skype, devido à localização do entrevistado.

O estudo foi conduzido por um aluno de doutorado do grupo, Daniel Cukier, e dois alunos de mestrado, Monna Cleide (autora deste texto) e João Machini, além da colaboração dos estudantes de graduação Caio Lente e Vinícus Pessoa Duarte. Nesta dissertação, os três alunos de pós-graduação foram responsáveis por executar as entrevistas. A codificação dos registros de áudio foi realizada pelo entrevistador, em parceria com os alunos de graduação, e o processamento dos resultados foi realizado individualmente pelos pesquisadores Monna e Daniel, sendo que este utilizou os dados para uma parte seu trabalho de doutorado e outros artigos, e a outra aluna, para esta dissertação de mestrado em si.

A meta inicial era entrevistar 60 pessoas, mas esta meta foi reduzida após a desistência de João Machini de Miranda em ingressar no programa de mestrado e sua subsequente decisão de ingressar como co-fundador na Startup Worldpackers ${ }^{2}$. A Tabela 3.2 mostra a quantidade de entrevistas, separadas por papeis, realizadas na cidade de São Paulo por cada membro do grupo.

\begin{tabular}{lllllll}
\hline Aluno & Aceleradoras & Governo & Investidor Anjo & Startup & VC & Total \\
\hline Daniel & 0 & 1 & 1 & 15 & 3 & $\mathbf{2 0}$ \\
João & 1 & 0 & 0 & 4 & 0 & $\mathbf{5}$ \\
Monna & 2 & 0 & 0 & 13 & 1 & $\mathbf{1 6}$ \\
Total & $\mathbf{3}$ & $\mathbf{1}$ & $\mathbf{1}$ & $\mathbf{3 2}$ & $\mathbf{4}$ & $\mathbf{4 1}$ \\
\hline
\end{tabular}

Tabela 3.2: Quantidade de entrevistas feitas por aluno.

Esta dissertação se concentra nos resultados restritos de São Paulo, mas todos os seus resultados englobarão também o estudo do Daniel, focado na comparação entre 3 ecossistemas: São Paulo, Nova Iorque e Tel-Aviv.

Na primeira fase, os candidatos à entrevista foram listados pelos membros do grupo de pesquisa através de um brainstorming (técnica em que as opções são apresentadas assim que vêm à mente, rapidamente e sem discriminação ou filtros), para serem avaliadas e selecionadas posteriormente. A lista de candidatos foi organizada em uma planilha, com informações sobre a startup, dados de contato e o entrevistador alocado. Foram considerados fatores como formação, número de startups em que já trabalhou, tempo de experiência no ramo e a atual situação da startup dentro do ciclo de vida. No entanto, esses fatores não foram usados para excluir candidatos, e sim para que que houvesse um

\footnotetext{
${ }^{2}$ http://www.worldpackers.com/
} 


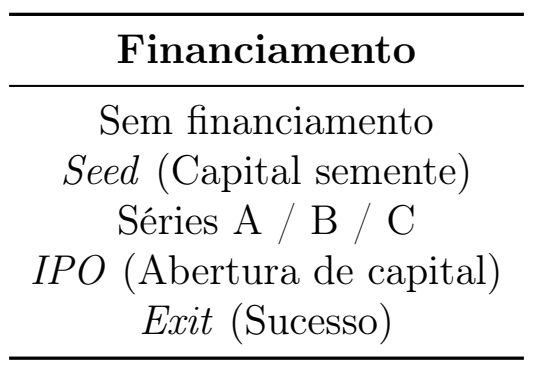

Tabela 3.3: Estágios de financiamento das startups participantes no estudo.

\begin{tabular}{c}
\hline Estágios de crescimento \\
\hline Bootstrapped (Financiamento próprio) \\
Very Early Stage \\
Early Stage \\
Financiamento $<=1 \mathrm{~m}$ \\
Financiamento $>1 \mathrm{~m}$ \\
IPO (Abertura de capital) \\
Exit (Sucesso) \\
\hline
\end{tabular}

Tabela 3.4: Estágios de crescimento das startups participantes no estudo.

controle, pois para que a pesquisa tenha resultados satisfatórios é importante que haja uma boa diversidade entre entrevistados de diferentes perfis. Assim, na falta (ou excesso) de um determinado perfil, buscou-se mais pessoas para suprir a carência.

Para empreendedores e profissionais de startups, foram considerados como fator de avaliação o tamanho e o estágio de financiamento. Esses estágios estão descritos na Tabela 3.3 e na Tabela 3.4 .

A primeira fase de entrevistas se deu a partir da terceira semana de maio de 2014, onde cada pesquisador teve como objetivo entrevistar pelo menos dois candidatos. Essas entrevistas serviram para testar a aplicação do modelo, assim como dar experiência e segurança aos pesquisadores para as etapas subsequentes. Após essa primeira fase, realizou-se uma reunião para discutir dúvidas e possíveis sugestões para a melhoria das entrevistas.

A partir desse momento, foi adotado um esquema de "bola de neve", onde indicações de outras pessoas que poderiam contribuir para o estudo foram pedidas para os primeiros participantes, incrementando assim a lista para a realização de novas entrevistas, e assim por diante. A ferramentas de perfis profissionais LinkedIn também foi utilizada para mapear possíveis entrevistados e entrar em contato com os mesmos.

Todas as entrevistas foram gravadas através de registros de áudio, feitos com gravadores digitais ou com os próprios celulares dos entrevistadores. Cada entrevista durou, em geral, entre 30 e 60 minutos, sendo a mais curta com $0 \mathrm{~h} 20 \mathrm{~m}$ e a mais longa com 1h51m. Nas entrevistas ocorridas nos locais de trabalho das startups, buscava-se observar detalhes como a organização do profissional e do time, o ambiente de trabalho, o comportamento do entrevistado, etc., para que a conversa fluísse da melhor maneira possível. Em alguns casos, o entrevistador também realizou anotações sobre as observações efetuadas no ambiente de trabalho e durante as entrevistas. 
Baseando-se nas questões de pesquisa do estudo, foram efetuadas as seguintes perguntas para a entrevista presencial:

1.1 Quais são os fatores em São Paulo que promovem o espírito empreendedor?

1.2 Quais são os fatores em São Paulo que desencorajam ou criam barreiras para o empreendedor?

2 Quais são os mecanismos institucionais em São Paulo que promovem o empreendedorismo? Por exemplo:

- Legislação;

- Instituições educacionais, científicas e tecnológicas;

- Agências e programas de governo municipal, estadual e federal;

- Fundos de investimento semente, investidores anjos, etc.;

- ONGs;

- Etc.

3 Você acredita que a educação tem um papel fundamental no empreendedorismo? Em casa? Ensino fundamental? Ensino médio? Universidade? Auto-educação? Educação informal? Educação de um modo geral ou educação voltada para empreendedorismo? Você pode pensar em materiais e mecanismos pedagógicos, implícitos ou explícitos, que nutrem o espírito empreendedor? Você já participou de alguma atividade de educação empreendedora (curso, workshop, aceleração, incubação)? Você acredita que há elementos que podem ser melhorados através da educação empreendedora?

4.1 Quais são as características dos empreendedores?

4.2 Quais são as características de times inovadores de sucesso (mistura entre introvertidos e extrovertidos?)? Quais são os papeis de diferentes tipos de pessoas? Diversidade é importante?

4.3 Qual é a principal motivação do empreendedor tecnológico: riqueza, fama, autoestima, prova da tecnologia, etc.?

5 Quais aspectos tecnológicos influenciam no sucesso de startups de software, e como? Em particular qual é o papel executado por Orientação a Objetos, Linguagens, Arcabouços, Padrões, Modelos e Arquiteturas? O seu time tem alguma preocupação com qualidade de código? Como você promove e controla isso? Você tem uma grande dívida técnica? Você controla isso de alguma forma?

6.1 Quais aspectos metodológicos influenciam no sucesso de startups de software, e como? Em particular qual é o papel executado por Métodos Ágeis, Lean Startup [Rie11] e Desenvolvimento do Cliente [BD12]? Quais práticas de metodologias ágeis você usa? Há alguma coisa em métodos ágeis que não funciona muito bem para sua empresa? Qual você considera o fator dominante para o sucesso de startups: um plano sistemático ou a intuição? Essa relação muda de acordo com o ciclo de vida da startup? 
6.2 O que você não faz muito bem e que gostaria de melhorar? Você já identificou algum erro que você cometeu na sua startup atual ou algo que deveria ter sido feito de outra forma?

7 Qual é a relação da sua companhia com Software Livre? Você usa? Você contribui? Você acredita que o Software Livre tem um papel significativo no ecossistema de startups?

8 Se você tivesse que citar três elementos chave para um ecossistema de startups saudável em um país ou região, quais seriam?

Para a classificação das respostas, as perguntas foram agrupadas dentro dos seguintes tópicos:

1. Fatores positivos e negativos

2. Institucional

3. Educação

4. Empreendedor, times e motivação

5. Tecnologias

6. Metodologias

7. Software Livre

8. Elementos fundamentais

Nem todas as questões foram perguntadas para cada entrevistado. As perguntas 5, 6.1 e 7, por serem de um caráter mais técnico, foram utilizadas apenas em conversas com pessoas especialistas no ramo.

Mesmo tendo uma série de perguntas pré-estabelecidas, os entrevistadores não necessariamente seguiam a lista como um roteiro rígido. Isso se deve ao fato de que, no decorrer do diálogo, muitas perguntas podiam ser respondidas ao mesmo tempo, ou uma resposta desencadear a resposta da outra pergunta, não necessariamente na ordem em que os assuntos estavam listadas no roteiro. Em alguns casos, uma resposta levava a novas perguntas não presentes no plano inicial.

Após a gravação da entrevista, o pesquisador geralmente estendia a conversa por alguns minutos, tanto para pedir sugestões de novos entrevistados quanto para ouvir a opinião do entrevistado sobre o processo e receber críticas e comentários adicionais. Ao fim de todo esse processo, a entrevista era catalogada nos arquivos do grupo para posterior análise.

\subsection{Codificação e análise dos dados}

Miles \& Huberman [MH94] descrevem as fases da análise qualitativa em três partes:

- Redução de dados (Data reduction): consiste no processo de selecionar, simplificar e transformar os dados registrados em texto resumido ou transcrições. Essa etapa é considerada parte do processo de análise, pois as próprias escolhas do analisador de quais observações inserir e como compactar os dados são decisões analíticas. 
- Exposição de dados (Data display): De uma maneira genérica, uma exposição é um conjunto de informações conciso e organizado que permite ao leitor fazer observações e tirar conclusões. Exposições como matrizes, gráficos, redes e quadros são bem mais eficientes que texto comum, e que, portanto, tornam a análise de dados mais eficiente.

- Conclusões e verificações (Conclusion Drawing and Verification): As hipóteses que foram formuladas durante a concepção do trabalho e a realização da pesquisa são finalmente descartadas ou validadas nessa fase. No entanto, essa não necessariamente é a etapa final: ela pode apontar a necessidade de uma nova iteração no processo de pesquisa.

Nesse estudo, a codificação trata dos primeiros dois itens, a redução e a exposição de dados, e a análise refere-se à etapa de conclusões.

Após a realização de cada entrevista, o entrevistador cataloga as informações pessoais do entrevistado e de sua empresa, incluindo uma foto, para facilitar a lembrança ao ouvir novamente as entrevistas. Esse registro foi feito através da plataforma colaborativa Evernote $^{3}$, com a criação de um caderno digital privado protegido por senha compartilhado apenas entre os membros da equipe de pesquisa. Os dados multimídia de cada entrevista correspondem a uma nota.

As notas estão no formato apresentado na Figura 3.1. Nesse caso, a imagem foi removida para que as informações de texto e o arquivo de áudio em anexo possar ser visualizados.

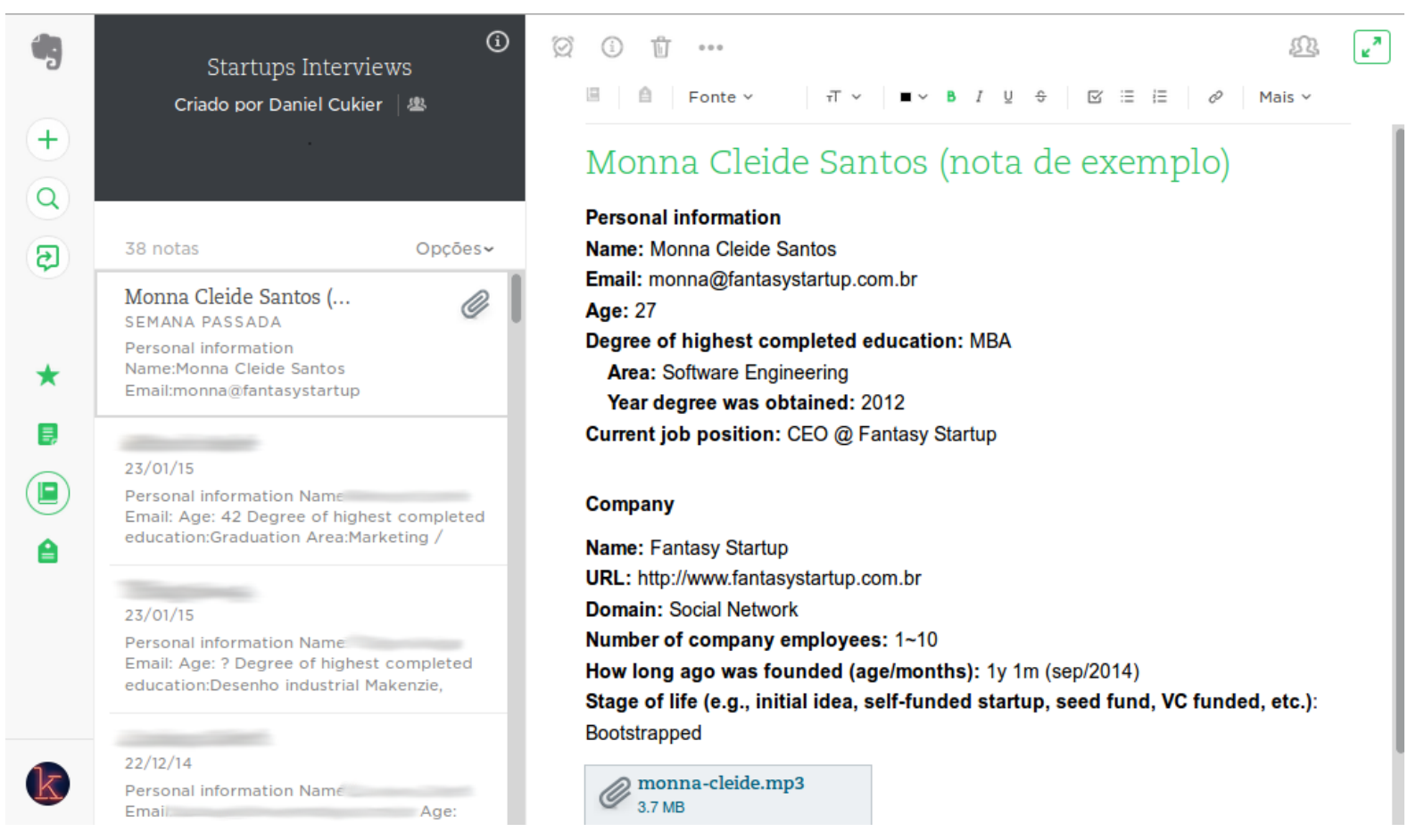

Figura 3.1: Nota de exemplo cadastrada na plataforma Evernote.

Para a codificação, as entrevistas foram ouvidas pelo entrevistador e mais uma pessoa do grupo de pesquisa, separadamente. O registro das respostas era feito pelos dois entrevistadores, e as divergências na interpretação eram discutidas entre ambos antes de serem inseridas no documento. Isso foi realizado dessa forma pois é uma boa prática

\footnotetext{
${ }^{3}$ http://www.evernote.com
} 
para estudos qualitativos como esse que haja uma triangulação entre os analistas, para que haja uma convergência nas informações e vieses sejam evitados [Pat99]. Não foram usados software de transcrição ou de sumarização automática.

Inicialmente, as informações importantes foram anotadas em um documento de texto simples. No entanto, isso gerou grande dificuldade, pois mesmo frases curtas, com duas linhas, já exprimiam uma apresentação visualmente carregada. Considerando o número proposto de 40 entrevistados, com gravações entre 30 e 60 minutos, e dois registros de respostas, o arquivo de registro ficaria facilmente com mais de 100 páginas. Assim, desenvolveu-se um sistema de tópicos, de forma que cada resposta a ser catalogada fosse sintetizada em frases que não ultrapassassem uma linha. Portanto, unir informações parecidas tornou-se mais fácil, e a comparação de resultados mais rápida. As respostas também passaram a ser codificadas em uma planilha colaborativa, o que facilitou a visibilidade e a navegação feita pelo codificador ao tomar notas das respostas de cada entrevistado.

A planilha, criada na plataforma Google Drive, contém em cada coluna o código das perguntas especificada no protocolo de pesquisa, mais o tópico que sintetize a pergunta. Nas linhas da planilha, foram colocados o nome do entrevistado e a empresa que ele representa. Cada resposta foi resumida em pequenas frases e, em certos casos, foram incluídas pequenas "etiquetas" para relacionar o mesmo comentário em várias perguntas diferentes (ex.: comentários sobre mais relacionamentos e trocas de experiências foram marcados com a etiqueta networking). A Figura 3.2 apresenta uma captura de tela de um pedaço da planilha original.

\subsection{Análise e resultados}

Após o processamento de todas as entrevistas na planilha de resposta, os tópicos mencionados foram agrupados e relacionados com as questões de pesquisa. A partir de cada frase fez-se novamente o processo de resumo, agrupando as respostas por temas ou palavras-chave. Comentários muito pontuais ou ditos por apenas uma pessoa foram tratados como opinião e considerados de menor relevância no estudo.

A análise dos dados processados em conjunto com o grupo de pesquisa coube exclusivamente à autora deste trabalho. O objetivo era construir teorias sobre determinado quesito, e agrupar argumentos que confirmassem ou não a teoria.

Na pergunta sobre educação, por exemplo, os entrevistados foram questionados sobre a eficiência da educação formal. Com base nas respostas, as frases eram separadas em grupos de teorias como "é boa", "é ruim", "não é necessária", "é necessária", "precisa melhorar", etc, conforme iam aparecendo nas entrevistas. Opiniões muito pessoais ou pouco compartilhadas com outros participantes da pesquisa foram movidas para outra seção, para que também pudessem ser avaliadas, mas com um peso bem menor.

As conclusões tomadas durante o processamento dos resultados também dão origem às considerações finais, tecidas a partir do levantamento do grupo de pesquisa de quais problemas impactam mais o ecossistema no momento. As propostas de sugestões também foram elaboradas pelo grupo a partir das sugestões dadas pelos entrevistados.

\subsubsection{Metodologias relacionadas}

Durante a fase inicial da pesquisa, foram estudados artigos em periódicos acadêmicos, congressos e livros da área, obtidos através de ferramentas de buscas acadêmicas. Apesar de esta pesquisa ter sido muito mais concentrada nos estágios mais iniciais, essa busca se dá em todas as etapas da pesquisa, em menor grau. Os estudos com foco semelhante 


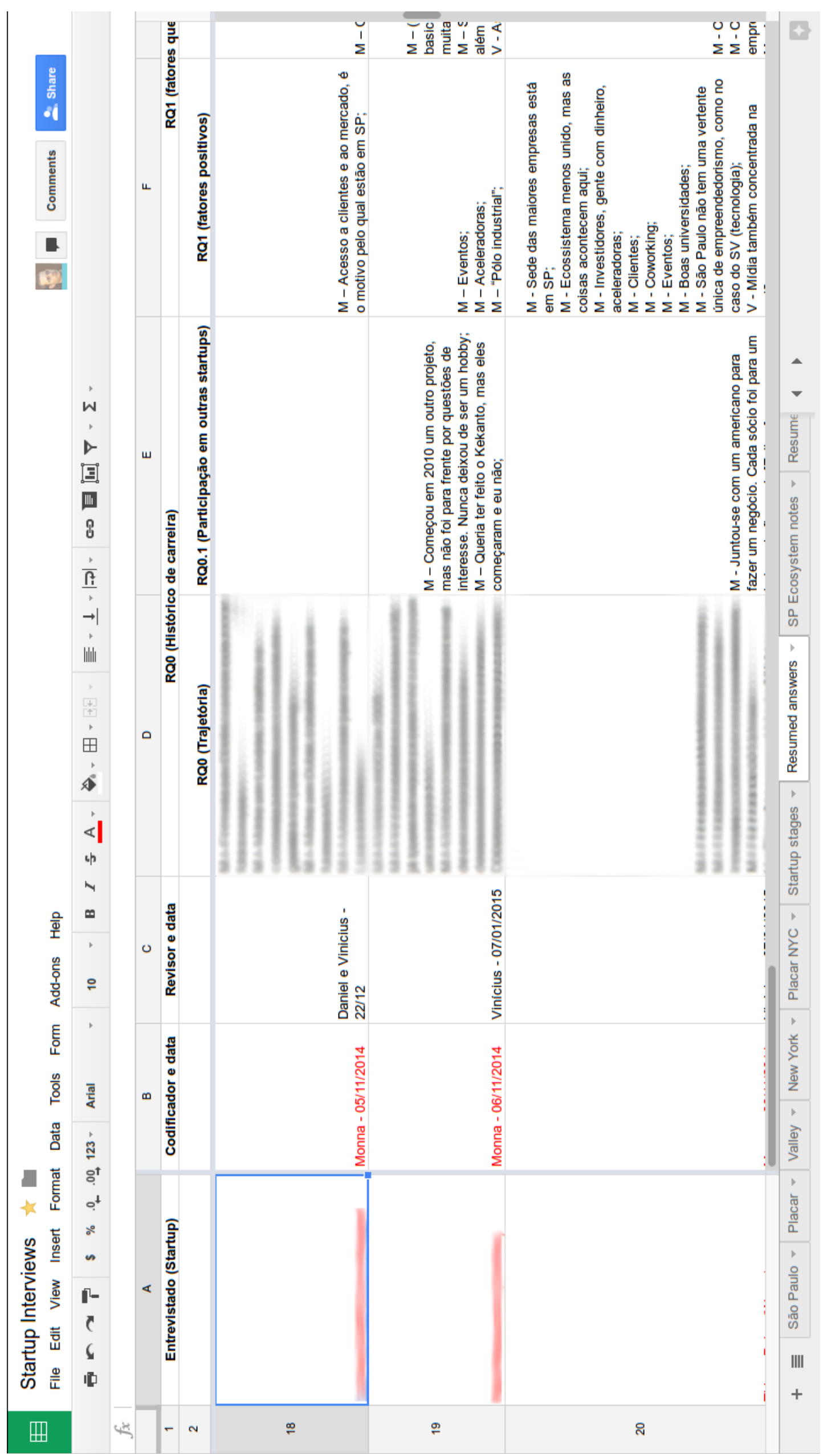

Figura 3.2: Planilha de codificação de dados na plataforma Google Drive. 
também foram úteis para corroborar as teorias extraídas da análise, bem como servir de parâmetro de comparação.

Os principais estudos que foram usadas durante o estudo para comparação são o relatório de ecossistemas da Compass [Com15] e o Índice de Cidades Empreendedoras Endeavor [End14]. Outros estudos semelhantes, como os relatórios global e de empreendedorismo no Brasil do Global Entrepreneurship Monitor [MGA+13, SAM15], um dos mais abrangentes estudos sobre empreendedorismo ao redor do mundo, também foram consultados.

O estudo realizado pela Endeavor [End14] é baseado em um arcabouço elaborado pela própria instituição, constituído de sete pilares que dão suporte a micro e pequenas empresas. A metodologia inclui também alguns dados quantitativos, tais como tamanho das cidades estudadas, e leva em consideração um momento de tempo específico, pois segundo os próprios autores, uma análise do ambiente empreendedor que reflita todo o histórico da cidade necessitaria de dados que tomariam tempo e esforço que excedem as intenções do relatório.

Em particular, um dos pilares contidos no estudo da Endeavor se cruza perfeitamente com a nossa metodologia: capital humano, contido na questão de pesquisa QP4 - Quais são as características de times inovadores e empreendedores de sucesso? Qual é a principal motivação do empreendedor de software?. Apesar de vários outros pilares também terem sido citados em outras perguntas da pesquisa (ex.: o ambiente regulatório foi bastante comentado pelos entrevistados na pergunta sobre características positivas e pontos a melhorar do ecossistema), nota-se uma clara intersecção entre o pilar de capital humano e nossa questão sobre o empreendedor e seus times.

Considera-se que, embora estudos mais aprofundados sejam necessários aos ecossistemas de cada cidade individualmente, o estudo realizado pela Endeavor apresenta uma clara visão comparativa de várias cidades brasileiras, e oferece a um possível empreendedor uma boa noção de vantagens e desafios que poderá enfrentar ao instalar sua empresa em determinado local, mesmo sem grande aprofundamento. Adicionalmente, o relatório faz um excelente trabalho ao cobrir uma lacuna de informação importante dentro de um país que começa a fazer estudos profundos voltados para características empreendedoras.

O relatório da Compass [Com15], por sua vez, oferece uma visão bem mais abrangente ao comparar ecossistemas ao redor do mundo. Novamente o quesito capital humano aparece como um ponto em comum com a metodologia desenvolvida pelo grupo de pesquisa, através do item "Talent" do relatório de ecossistemas globais. Os outros itens da pesquisa, que não estão presentes neste estudo, têm relação direta com a taxa de êxitos e saídas de startups, presença de fundos de investimentos e quantidade de dinheiro investido por eles, itens que não foram levados em consideração em nossa metodologia, apesar de terem sido comentados de um modo geral pelos entrevistados ao discutir os organismos institucionais presentes na cidade de São Paulo.

Por fim, os estudos do Global Entrepreneurship Monitor seguem um arcabouço conceitual desenvolvido e aprimorado por eles durante os últimos 16 anos [SAM15], que serve de base para os surveys (método de pesquisa, geralmente realizado através de questionários, que busca informações sobre características, opiniões ou ações de um determinado grupo de pessoas [FOSM00]) realizados pelo grupo a partir de 2014 em vários países, inclusive no Brasil.

Uma grande diferença entre os dois relatórios globais citados aqui (GEM e Compass) é a abrangência: enquanto a Compass se restringe aos 20 melhores ecossistemas de startups no globo, baseando-se nas opiniões de empreendedores de 25 países (não se sabe se os outros 5 países chegaram a ser avaliados), o relatório mundial do GEM inclui 67 países, 
divididos em três categorias de acordo com a fase do desenvolvimento econômico em que se encontra: impulsionada por fatores, pela eficiência ou pela inovação.

Adicionalmente ao relatório global, o Global Entrepreneurship Monitor produz regularmente relatórios mais aprofundados de cada país ou de determinadas regiões (as ilhas do Caribe, por exemplo). O relatório mais recente sobre o Brasil, datado de 2013 $\left[\mathrm{MGA}^{+} 13\right]$, traz alguns dados demográficos sobre o empreendedor, sua localização, taxas de empreendedorismo e sua comparação com índices mundiais, o perfil dos empreendedores e características dos negócios, a mentalidade empreendedora da população, os organismos de apoio, as condições do investimento informal e por fim as condições para empreender no Brasil. Este é um dos estudos mais completos sobre o cenário empreendedor brasileiro, e sua frequência de renovação a cada 1 a 2 anos permite traçar um panorama histórico bastante amplo para análise; porém, por se tratar de empreendedorismo de um modo geral, muitas vezes esses dados destoam do que se apresenta nas startups. Um exemplo disso é a porcentagem de mulheres, que aparece como sendo ligeiramente superior no estudo (51,4\%, em comparação com os 48,6\% homens), mas que no ecossistema de startups (e no meio de tecnologia de um modo geral) é uma minoria e representa um problema a ser solucionado.

Os pontos de intersecção entre essas metodologias, em comparação com a desenvolvida pelo grupo, podem ser visualizados na Tabela 3.5. Os tópicos das perguntas de entrevista realizadas para esta dissertação estão listadas na coluna da esquerda, e os itens de outros que correspondem ou apresentam similaridades a eles estão representados em negrito na tabela.

\begin{tabular}{llll}
\hline & Endeavor 2015 & $\begin{array}{l}\text { Compass } \\
2015\end{array}$ & GEM2013 \\
\hline $\begin{array}{l}\text { Fatores positivos e ne- } \\
\text { gativos }\end{array}$ & $\begin{array}{l}\text { Infraestrutura, ambi- } \\
\text { ente, mercado, acesso } \\
\text { a capital }\end{array}$ & $\begin{array}{l}\text { Condições para o em- } \\
\text { preendedor }\end{array}$ \\
$\begin{array}{l}\text { Institucional } \\
\text { Educação }\end{array}$ & $\begin{array}{l}\text { Capital humano, cul- } \\
\text { tura, inovação }\end{array}$ & Busca por apoio \\
$\begin{array}{l}\text { Empreendedor, times } \\
\text { e motivação }\end{array}$ & $\begin{array}{l}\text { Capital humano } \\
\text { Tecnologias } \\
\begin{array}{l}\text { Metodologias } \\
\text { Software Livre }\end{array}\end{array}$ & $\begin{array}{l}\text { Perfil do empreende- } \\
\text { dor }\end{array}$ \\
$\begin{array}{l}\text { Elementos fundamen- } \\
\text { tais }\end{array}$ & & \\
\hline
\end{tabular}

Tabela 3.5: Comparação entre metodologias de avaliação de ecossistemas.

A clara vantagem deste estudo se dá em uma profunda análise da parte técnica das startups, suas tecnologias e metodologias, que não foram citados em outros estudos; entretanto, por ser uma análise qualitativa, certos dados a respeito de cidades e taxas de investimento que são citados nos outros relatórios não foram levados em consideração neste.

Baseado no que foi desenvolvido nesta dissertação, o aluno de doutorado Daniel Cukier 
elaborou uma proposta de um modelo de maturidade para ecossistemas [CKK15a]. O estudo também está em vias de ser replicado por um aluno de graduação da Universidade de Brasília dentro do ecossistema da cidade, e espera-se que novos estudos e relatórios surjam a partir deste material.

Os resultados da análise são apresentados a seguir. 


\section{Capítulo 4}

\section{Resultados}

Nesta seção, apresentamos os resultados obtidos com o processamento das respostas obtidas nas entrevistas e o mapa do ecossistema construído a partir desses resultados.

\subsection{Respostas das perguntas de pesquisa}

Esta seção contém um resumo das respostas levantadas em entrevistas a partir das perguntas de pesquisa citadas na Seção 3.2. Em alguns momentos, usa-se referências da literatura relacionada e observações dos pesquisadores para complementar essas informações.

\section{QP1 - Quais são as características socioculturais de São Paulo que fomentam o espírito empreendedor?}

Um dos fatores mais citados entre os entrevistados foi a presença de todos os elementos fundamentais para um ecossistema empreendedor. Esses elementos, também conhecidos como domínios do ecossistema empreendedor, estão presentes na Figura 4.1.

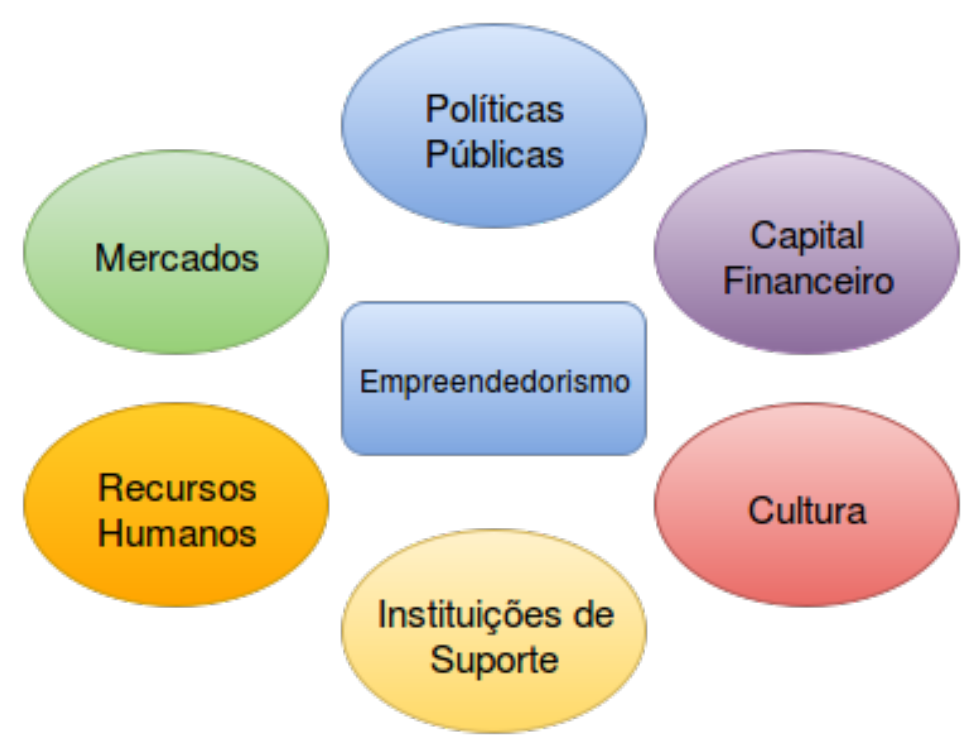

Figura 4.1: Dominios do ecossistema empreendedor. ${ }^{1}$ 
Hoje, a cidade concentra várias entidades de apoio, tais como incubadoras, aceleradoras, fundos de investimento e grupos de investidores anjos, e com isso, um capital específico voltado para o empreendedorismo. A cada dia despontam também mais eventos focados nesse tema, que além de acrescentarem à educação empreendedora, são uma grande ferramenta de networking. Apesar de outras cidades brasileiras também possuírem esses elementos, a percepção é que eles ocorram em menor grau. Boa parte dos entrevistados acredita que esses elementos são bem mais fortes em São Paulo. Também destacou-se, em menor número, a presença de certos componentes particulares da cadeia, tais como espaços de coworking e serviços de contabilidade específicos para startups, que segundo um entrevistado, "só podem existir em um lugar que tem demanda para esses serviços".

O segundo ponto mais citado foi a polarização que a capital desencadeia. São Paulo hoje é um dos mais importantes centros financeiros do mundo, atraindo clientes e investidores de todas as partes do globo. Isso leva ao surgimento de um amplo mercado consumidor, com vários gêneros e categorias de consumo. Além disso, essas condições promovem a vinda de talentos de diversas regiões do país, que buscam melhores oportunidades de mercado, maiores salários, evolução na carreira, melhora de sua condição de vida, etc. A presença de pessoas é um fator crucial para o sucesso de startups, tanto pela mão de obra quanto pelo mercado consumidor, e ter elementos que atraem pessoas conduz à vinda de mais empresas e mais clientes, gerando um ciclo virtuoso. Nas palavras de um dos entrevistados, "São Paulo melhora porque é São Paulo".

Aliado a isso, o estado de São Paulo também concentra uma vasta gama das melhores universidades brasileiras e do mundo. No ranking de universidades do jornal Folha de São Paulo $^{2}$, dos 10 primeiros lugares, 4 são instituições encontradas no estado, 2 delas com campus na capital. Esse também foi considerado um fator relevante para o destaque de São Paulo como um ecossistema empreendedor. Isso influencia diretamente na qualificação da mão de obra, gerando para o ecossistema um capital humano valiosíssimo.

A presença de uma economia forte e bem aquecida na última década também surgiu como um fator determinante para o destaque da cidade. Vários participantes citaram a capital do estado de São Paulo como sendo parte de uma "economia viva". Segundo eles, a cidade faz parte de uma economia de escala, e dentro de suas organizações é visivel o conceito de "sociedade aplicada", onde toda a sociedade trabalha para "gerar resultados para a região".

Ainda em relação às pessoas, mais um fator citado por empreendedores é a presença de muitas outras startups na região e, portanto, outros empreendedores. Isso inclui dois casos completamente distintos: o primeiro deles é o de personalidades que obtiveram êxito durante sua carreira. Essas pessoas, além de compartilharem suas histórias de sucesso e, assim, motivar novos empreendedores a se arriscarem em novos negócios, trazem também a oportunidade de uma troca de experiências maior, facilitando a jornada do iniciante. Adicionalmente, empreendedores que tiveram sucesso com suas empresas podem investir os lucros em outras startups, realimentando, assim, o ecossistema. No entanto, esses ainda são casos muito isolados. Os fatores negativos e pontos a melhorar da cidade serão retratados detalhadamente na Seção 5.1.

O segundo caso é o do empreendedor "comum", que está trabalhando em sua startup buscando o sucesso. Alguns entrevistados afirmam que estar próximo de empreendedores em estágios semelhantes permite que ambos cresçam juntos e compartilhem sucessos e fracassos em determinados pontos em comum. Um exemplo encontrado durante as

\footnotetext{
${ }^{1}$ Adaptado de: Carlos Arruda, et al. "O Ecossistema Empreendedor Brasileiro de Startups: uma análise dos determinantes do empreendedorismo no Brasil a partir dos pilares da OCDE". Relatório técnico, 2013.

${ }^{2}$ http://ruf.folha.uol.com.br/2014/rankingdeuniversidades/, último acesso em 22/01/2015.
} 
entrevistas é o de duas startups que, durante sua implantação, decidiram dividir o aluguel de uma casa para diminuir os custos.

Uma vantagem apontada na pesquisa por um funcionário de uma aceleradora é que, ao contrário do Vale do Silício, que concentra quase unicamente startups de tecnologia, São Paulo não tem uma vertente única de empreendedorismo, e isso pode converterse futuramente em uma vantagem competitiva, ou até mesmo mudar radicalmente, caso haja alguma influência que faça as startups adotarem algum ramo específico.

No entanto, o Brasil ainda carece muito de uma cultura empreendedora. Apesar do empreendedorismo ser um tema recorrente na mídia televisiva, esse é um fator visto como negativo pelos entrevistados, pois hoje passa-se uma visão distorcida do empreendedor, sendo este alguém que fica rico com facilidade, que tem um polo empresarial milionário, quando até mesmo o dono de uma padaria no bairro é empreendedor. Nas palavras de um dos participantes, "A mídia cria uma aura sobre empreendedorismo que não existe".

O impacto da mídia se comprova nas novelas, que geralmente tem personagens principais que ora são donos de empresas multimilionárias, construídas de geração em geração e passadas de pai para filho, ora empresas que despontam do zero ao topo em alguns capítulos. Isso traz uma frustração no indivíduo que, por exemplo, inventou um produto novo excelente mas que não se vê como empresário de sucesso por não ter enriquecido. Adicionalmente, o falso glamour citado pelos empreendedores que a mídia cria é um péssimo motivo para empreender, pois há muito trabalho duro que não é mostrado. Mais detalhes sobre as motivações dos empreendedores podem ser conferidas na análise da questão de pesquisa QP4 - Quais são as características de times inovadores e empreendedores de sucesso? Qual é a principal motivação do empreendedor de software?.

Alguns dos entrevistados afirmam que, no imaginário popular, ser empreendedor é um último recurso de quem não conseguiu ter sucesso ao se estabelecer em uma grande empresa ou em um cargo público. Não foram encontrados artigos ou material de referência que sustentem essa afirmação; no entanto, é fato que o brasileiro tem uma forte tendência ao "empreendedorismo por necessidade", apesar de este quadro ter evoluído nos últimos anos [GAM12, $\left.\mathrm{MGA}^{+} 13\right]$.

Segundo os entrevistados, também há entre os empreendedores uma crença errônea de que sair da escola é algo bom, e que a faculdade não tem serventia. Isso se deve a poucos casos de sucesso de pessoas que criaram um produto inovador e ficaram milionários sem ter concluído os estudos, como se estudar não fizesse diferença alguma nas suas chances de sucesso.

A cultura de falha também é um fator decisivo para o desenvolvimento do ecossistema empreendedor. Ao contrário de outros ecossistemas, como por exemplo o de Israel, em que as falhas são percebidas como algo que traz valor ao empreendedor, no Brasil alguém que falha é visto não como alguém que tentou, mas sim como alguém que fracassou, e deve carregar o estigma de rejeição social que isso acarreta. É preciso ensinar as crianças na escola a falhar, e que apenas tentando criar, falhando e perseverando após isso é que poderemos ter um ambiente saudável para o espírito empreendedor e o pensamento disruptivo.

Alguns dos entrevistados acreditam que a grande migração de brasileiros (e até estrangeiros) para a cidade é um fator positivo de São Paulo, pois os novos moradores chegam predispostos a trabalhar para construir seus sonhos, dispostos a correr riscos e mais resistentes ao fracasso. No entanto, segundo a Compass, a taxa de empregados estrangeiros em startups é de apenas $7 \%$ [Com15]. Acredita-se, portanto, que esse é um fator mais presente em empresas tradicionais, e que a presença de imigrantes beneficia startups de 


\begin{tabular}{cc}
\hline Aceleradoras (Nacionais) & Aceleradoras (Estrangeiras) \\
\hline Aceleratech & 500 Startups \\
\hline Acelera Partners & Plug n' Play \\
Artemisia & Redpoint e.ventures \\
Baita Aceleradora & \\
Germinadora & \\
Gema Ventures & \\
Quintessa & \\
Startup Farm & \\
Tree Labs & \\
\hline
\end{tabular}

Tabela 4.1: Principais aceleradoras nacionais e internacionais em São Paulo.

software ao melhorar a cultura e inspirar os empreendedores.

A família, segundo os entrevistados, também tem influência na formação do caráter empreendedor de um determinado indivíduo. Os motivos para isso são o incentivo que a família pode oferecer à carreira empreendedora e o exemplo prático de pais ou parentes que comandam empresas. Familiares também podem ajudar na construção de certas características do caráter empreendedor, tais como correr riscos, e na formação do caráter através dos valores e da ética.

\section{QP2 - Quais são os mecanismos institucionais em São Paulo que promovem ou dificultam o empreendedorismo?}

Apresenta-se aqui, juntamente com as respostas sobre mecanismos institucionais, exemplos importantes de entidades que promovem a ação empreendedora no ecossistema de São Paulo. Nem todas as instituições da tabela foram explicitamente citadas, mas foram incluídas posteriormente pelo grupo de pesquisa ao fazer o mapeamento do ecossistema por meio da mídia especializada.

Duas das entidades consideradas mais relevantes como mecanismos institucionais para São Paulo foram incubadoras e aceleradoras. Apesar de São Paulo contar com várias incubadoras, a única mencionada de maneira específica foi o CIETEC, incubadora de empresas de base tecnológica localizada dentro da Cidade Universitária da USP.

As aceleradoras são vistas por uma parte dos entrevistados como responsáveis por trazer uma boa parte do conhecimento necessário às startups, através de cursos e mentorias, assim como apresentar uma oportunidade de se relacionar com outros empreendedores em etapas semelhantes e oferecer um espaço dedicado para as startups planejarem e exercerem suas atividades. Segundo um dos entrevistados, as aceleradoras e incubadoras provêm alguma formação empreendedora, e outro entrevistado afirma que o processo de aceleração cumpre uma parte do papel educacional voltado para o empreendedorismo que hoje falta no ensino brasileiro. Exemplos de aceleradoras importantes presentes no ecossistema paulistano estão listados na Tabela 4.1.

Algumas entidades e programas foram destacadas nas entrevistas como sendo elementos importantes para o fortalecimento do ecossistema empreendedor, especialmente o paulistano. Dentre elas, temos:

- Endeavor, organização de apoio a empreendedores; 
- SEBRAE, o principal organismo de apoio ao micro e pequeno empreendedor hoje no Brasil;

- FAPESP, fundo de apoio à pesquisa no estado de São Paulo, em particular seu programa PIPE (Programa Pesquisa Inovativa em Pequenas Empresas) ${ }^{3}$;

- BNDES;

- Finep, uma empresa pública vinculada ao MCTI, idealizadora de programas de financiamento que anteriormente eram concedidos pelo BNDES;

- ABStartups.

Algumas outras instituições foram citadas pontualmente, tais como:

- Laboratório de Mobilidade Urbana da SPTrans (organização municipal que gerencia o sistema de ônibus paulistano);

- ABRAII (Associação Brasileira de Empresas Aceleradoras de Inovação e Investimento);

- Choice, rede universitária voltada para empreendedorismo social da Artemisia (organização sem fins lucrativos voltada para negócios de impacto social);

- Fundação Estudar, organização sem fins lucrativos voltada para educação empreendedora;

- Brazil Innovators, rede global para conexão entre empreendedores no Brasil e no Vale do Silício;

- Empretec, programa do SEBRAE baseado na metodologia criada pela ONU (Organização das Nações Unidas) para desenvolvimento de características empreendedoras e identificação de oportunidades de negócio.

Programas do governo também foram citados de uma maneira geral, embora haja entrevistados que afirmem que "não há incentivo por parte do governo" ao empreendedorismo. Um programa citado explicitamente durante a entrevista foi a Hackathon da Prefeitura de São Paulo.

Em relação a eventos, o mais citado foi o Startup Weekend, programa em que os participantes são convidados a desenvolver uma ideia e iniciar seu negócio em $54 \mathrm{~h}$. Alguns exemplos de importantes instituições de apoio financeiro em São Paulo estão listadas na Tabela 4.2 .

\section{O investimento no ecossistema brasileiro}

Grupos de investimento também foram citados como uma parte importante do institucional do ecossistema. Os fundos de investimento, bastante criticados durante as entrevistas, apresentam-se como uma opção para captar recursos, especialmente na fase de crescimento da startup - entretanto, os entrevistados afirmam que isso não é suficiente.

No Brasil, "faltam mais investidores de qualidade". As principais queixas são: sua imaturidade para entender o ciclo de inovação; a cobrança excessiva de resultados como lucro, receita e conversão de clientes; a incompatibilidade entre o (baixo) risco que eles

\footnotetext{
${ }^{3}$ http://www.fapesp.br/58
} 


\begin{tabular}{|c|c|c|c|}
\hline Anjos & VCs & Órgãos de fomento & $\begin{array}{l}\text { Programas de fo- } \\
\text { mento }\end{array}$ \\
\hline Anjos do Brasil & 500 Startups & BNDES & InovAtiva (MDIC) \\
\hline \multirow{9}{*}{$\begin{array}{l}\text { Mulheres } \\
\text { vestidoras } \\
\text { (MIA) }\end{array}$} & Accel Ventures & CAPES & PIPE (Fapesp) \\
\hline & Bolt Ventures & $\mathrm{CNPq}$ & Startup Brasil \\
\hline & Confrapar & Desenvolve SP & \\
\hline & Fir Capital & Fapesp & \\
\hline & Fundo Criatec & Finep & \\
\hline & $\begin{array}{l}\text { Fundo Investe } \\
\text { SP }\end{array}$ & Investe SP & \\
\hline & Kaszek Ventures & & \\
\hline & Monashees & & \\
\hline & Vox Capital & & \\
\hline
\end{tabular}

Tabela 4.2: Principais organismos de investimento no estado de São Paulo.

correm atualmente em termos de apoio à startup e o (alto) retorno cobrado por essa ajuda; a alta concentração dos fundos em determinados segmentos de mercado; e a falta de fundos dedicados a capital semente, que segundo os entrevistados, é o mais difícil de ser adquirido e o mais necessário hoje em relação ao estado do ecossistema brasileiro. Apesar disso, o investimento financeiro hoje não é uma preocupação primária, pois segundo dois dos entrevistados, um produto bom acaba encontrado apoio financeiro naturalmente.

Os grupos de anjos também estão lentamente ganhando força e se popularizando no Brasil. No entanto, as aceleradoras foram consideradas por um dos entrevistados como "um serviço melhor do que os anjos", já que estes, assim como fundos de investimento, tendem a correr pouco risco. Além disso, uma queixa de um dos entrevistados foi que muitos anjos acabam "pulverizando o dinheiro em muitas startups", o que faz com que o investimento não seja suficiente para nenhuma delas.

Aqui, alguns pontos já citados na questão de pesquisa anterior foram novamente citados. Alguns deles são: os mentores, presentes na cidade pela alta concentração de startups, os espaços de coworking, algumas empresas que ou são voltadas para atender problemas recorrentes em startups, como contabilidade e advocacia; ou se mobilizam para fomentar o empreendedorismo com eventos e até mesmo financiamento, e a própria família do empreendedor.

As universidades ainda não têm um papel significativo para o ecossistema, segundo alguns dos entrevistados, mas muitas delas estão trabalhando ativamente para reverter esse quadro. O Centro de empreendedorismo da FGV e a Universidade de São Paulo, bem como alguns organismos vinculados a ela, tais como o NEU (Núcleo de Empreendedorismo da USP), foram citados durante a pesquisa. Maiores detalhes sobre universidades serão discutidos futuramente, na questão de pesquisa QP3 - Quais são os mecanismos educacionais em São Paulo que promovem ou dificultam o empreendedorismo?.

Algumas das principais instituições de apoio ao empreendedorismo em São Paulo estão 


\begin{tabular}{|c|c|c|c|}
\hline Incubadoras & Parques tecnológicos & Universidades & Outros \\
\hline $\begin{array}{l}\text { AGENDE (Guaru- } \\
\text { lhos) }\end{array}$ & Criatec (Campinas) & FIAP & $\begin{array}{l}100 \quad \text { Open } \\
\text { Startups }\end{array}$ \\
\hline CIETEC & Parqtec (São Carlos) & FEI & ANPEI \\
\hline $\begin{array}{l}\text { Innova (Santo An- } \\
\text { dré) }\end{array}$ & $\begin{array}{l}\text { Parque tecnológico do } \\
\text { Jaguaré (São Paulo) }\end{array}$ & FGV & Endeavor \\
\hline $\begin{array}{l}\text { Inova Unicamp } \\
\text { (Campinas) }\end{array}$ & $\begin{array}{l}\text { Parque tecnológico de } \\
\text { Ribeirão Preto }\end{array}$ & Mackenzie & \\
\hline \multirow[t]{5}{*}{$\begin{array}{l}\text { Supera } \\
\text { Preto) }\end{array}$} & $\begin{array}{l}\text { Parque tecnológico de } \\
\text { São Carlos }\end{array}$ & PUC & \\
\hline & $\begin{array}{l}\text { Parque tecnológico de } \\
\text { São José dos Campos }\end{array}$ & UNESP & \\
\hline & & Unicamp & \\
\hline & & Unifesp & \\
\hline & & USP & \\
\hline
\end{tabular}

Tabela 4.3: Principais instituições de apoio ao empreendedorismo no estado de São Paulo.

listadas na Tabela 4.3. Um ponto importante ao observar essas instituições é que apenas um parque tecnológico está localizado na cidade de São Paulo.

\section{QP3 - Quais são os mecanismos educacionais em São Paulo que promovem ou dificultam o empreendedorismo?}

A educação formal e a informal caminham juntas na educação para o empreendedorismo. Há um consenso entre os entrevistados de que ambas modalidades são fundamentais, mas há uma divergência na escolha de qual delas é a mais importante para o futuro empreendedor.

\section{Educação formal}

A importância da educação formal está nas habilidades que ela traz. Segundo os entrevistados, além da base teórica que o ensino traz naturalmente, em todas as suas fases, o ensino desenvolve também um contexto social: ele ajuda o aluno a dialogar com as pessoas, ser responsável e sociável. Maiores detalhes sobre como essas habilidades influenciam na carreira empreendedora estão descritos na questão de pesquisa QP4 Quais são as características de times inovadores e empreendedores de sucesso? Qual é a principal motivação do empreendedor de software?.

O conhecimento sólido também é essencial para a inovação, pois ele fornece os fundamentos teóricos necessários para produzir pesquisa e criar ou modificar produtos, serviços ou processos, mostrando o caminho pelo qual algo pode ser aprimorado. Esse processo gera inovação e traz vantagem competitiva para os detentores da mesma. Citando um dos participantes da entrevista, "não dá para ser empreendedor de tecnologia sem ter bases sólidas". Outro fator que traz à tona a importância da educação formal é a construção do pensamento crítico: o conhecimento dá as bases para a formulação do pen- 
samento inovador, ajuda a pensar na solução de problemas e constrói no aluno a noção de que algo pode ser mudado ou melhorado.

Entretanto, a educação formal no Brasil está longe de oferecer todos esses recursos. Apesar de termos uma boa concentração de universidades de ponta em São Paulo, ainda temos poucos centros de pesquisa de maneira geral no Brasil. A educação também passa por um problema de caráter estrutural: poucas instituições de ensino oferecem um incentivo real à inovação e ao pensamento crítico, assim como uma educação voltada para o empreendedorismo. Mais ainda: um entrevistado formado em administração de empresas afirma que os poucos cursos e disciplinas específicos de empreendedorismo feitos em universidades são elaborados e fornecidos por pessoas que em sua maioria também não são empreendedoras, tendo no máximo participado em cargos de gestão de grandes empresas, colocando assim em xeque a validade prática desse tipo de recurso.

Uma queixa muito comum dentre os entrevistados é a de que a faculdade hoje possui um foco voltado especificamente para o mercado de trabalho. Segundo um experiente empreendedor, a educação está "defasada com a realidade". Outro entrevistado comentou que ouvia explicitamente dos professores frases como: "Quando vocês forem trabalhar em uma empresa...". Em suma, muitos dos empreendedores acreditam que os alunos hoje são condicionados a serem funcionários de grandes empresas ou seguirem a carreira pública.

O incentivo a assumir postos de trabalho considerados estáveis não deve ser condenado. Entretanto, a relação entre o mercado e a universidade está lentamente deixando de ser uma relação de consumo, onde as empresas contratam o profissional moldado pela faculdade, e entrando em uma relação de parceria, onde as pesquisas desenvolvidas por um podem ser utilizadas e aprimoradas pelo outro, através do ecossistema de inovação. $\mathrm{O}$ próprio mercado hoje exige um profissional que saiba empreender dentro do seu próprio posto de trabalho, seja tendo proatividade, dando boas opiniões e sabendo participar nas decisões da empresa quando possível, e se essas habilidades não começarem a ser cultivadas nos estudantes, a educação formal apenas se tornará mais defasada e tenderá a ser descartada.

\section{Educação informal}

A educação informal do empreendedor vem de diversas formas, seja em conteúdo físico como livros e blogs, seja na troca de informações com pessoas mais experientes ou em eventos temáticos, ou até mesmo do conhecimento empírico, adquirido através da prática. Este é um dos motivos pelos quais afirma-se que a educação informal é mais importante que a fornecida em escolas ou universidades: para um dos entrevistados, "empreendedores aprendem no erro, no acerto, e em ser autodidata: lendo, conversando, discutindo".

Hoje qualquer pessoa encontra com facilidade livros, blogs, manuais, artigos e podcasts sobre vários temas relacionados a empreendedorismo: captação de recursos, crescimento e escalabilidade, clientes, como fazer um bom pitch (fala de elevador), etc. Um ponto ruim disso é que a maioria do material "didático" feito para empreendedores surge do Vale do Silício, o que pode gerar noções erradas de que tudo que funciona bem para lá irá funcionar automaticamente aqui, sem levar em considerações características pessoais do ecossistema local e possíveis vantagens competitivas que poderiam trazer mais destaque à região.

O fator prático do aprendizado empreendedor dá a ele uma certa democracia, pois 
não é necessário portar um diploma ou ter passado vários anos em uma instituição de ensino para abrir seu próprio negócio. "O conhecimento facilita, mas vale mais a vontade de fazer", de acordo com um dos participantes da entrevista. A prática acaba trazendo a teoria, através do conhecimento empírico, e há muitos detalhes do que ocorre no cotidiano de uma empresa que são impossíveis de serem apresentados em uma sala de aula. "O empreendedorismo na teoria é mais fácil".

Há quem chegue inclusive a afirmar que a educação formal pode se tornar um empecilho. Um dos entrevistados, que não completou o ensino fundamental, afirma que, no caso das "empresas de garagem", o estudo pode minar o processo de descoberta, fazendo com que o empreendedor perca oportunidades de mercado que só se percebe durante a prática. É importante lembrar que o conhecimento teórico é fundamental para a inovação de base, mas não para a inovação de mercado; qualquer pessoa, sendo experiente ou não, pode vislumbrar oportunidades de mudança que tenham potencial econômico.

Vale ressaltar também que a educação é útil, mas não deixa de ser uma ferramenta, e que pode ser utilizada ou não, e da maneira correta ou não, pelo empreendedor. Assim, ela serve não como um fator crítico, mas como um item complementar ao conjunto de habilidades requeridas para ser um empreendedor de sucesso. Alguns dos entrevistados não fizeram curso superior ou nem mesmo concluíram o ensino básico, mas isso não os impediu de terem sucesso em suas carreiras e de virarem mentores para as próximas gerações. Um entrevistado, que já tem algumas falhas no currículo, afirma que o curso de empreendedorismo ideal deve ser "10\% teórico, $30-40 \%$ cases de sucesso e falha e $50-60 \%$ prático".

\section{Outras fontes de aprendizado}

Apesar de muitos eventos focados para empreendedores estarem despontando em São Paulo, o ecossistema local ainda carece de eventos sobre temas específicos, coisa bastante presente em outros lugares do globo. No Vale do Silício, por exemplo, além dos tradicionais eventos de pitches, competições e treinamentos, certas associações realizam os chamados Entrepreneur Socials, com caminhadas, corridas e passeios de bicicleta, oferecendo assim um momento de confraternização informal em que empreendedores podem desfrutar de momentos de lazer e discutir sobre negócios sem uma atmosfera séria ou rígida de "evento fechado", com horários de início e fim.

As pessoas envolvidas com esses eventos também são de uma importância crucial. É preciso balancear bem o que será oferecido em cada evento em termos de conteúdo, para que não seja uma perda de tempo para o empreendedor. Nesse quesito, os mentores são fundamentais: ainda temos poucos casos de sucesso no Brasil, e essas pessoas bem-sucedidas precisam aparecer e compartilhar sua história com o máximo de pessoas possível, para que possamos ter mais pessoas interessadas em se arriscar e que a sociedade de um modo geral possa ter uma melhor compreensão do cotidiano e da importância do empreendedor.

\section{QP4 - Quais são as características de times inovadores e empreen- dedores de sucesso? Qual é a principal motivação do empreendedor de software?}

Quando questionados sobre as características que compõem os empreendedores e seus times, os participantes da entrevista deram respostas bem distintas. Esperava-se com essa 
questão saber mais sobre aspectos socioculturais dessas pessoas, mas quase a totalidade das respostas gira em torno de fatores e traços interpessoais.

\section{Empreendedores e times}

Com relação aos fundadores de empresas, foram listadas uma série de qualidades requeridas ou tidas como importantes para que ele(a) tenha sucesso em sua carreira. Dentre elas, as que obtiveram mais destaque foram: ser propenso a riscos, resiliência, ter visão de longo prazo do negócio e de onde quer chegar, ser desapegado (de bens materiais, estabilidade, e até mesmo dogmas), paixão pela ideia e/ou pelo negócio (traduzido por alguns como "ter brilho nos olhos"), persistência, ter foco em resultados, dedicação e coragem.

Quando questionados, algumas pessoas responderam que, em sua visão, o empreendedor fundador hoje é alguém, na maioria das vezes um homem jovem (entre 20 e 30 anos), que tem facilidade com tecnologia e tem ou já teve algum contato com o exterior. Há também quem o vê como um estudante universitário que pensa em montar o próprio negócio a partir de alguma ideia. Essa imagem não é partilhada por todos os entrevistados; alguns deles afirmam explicitamente que a idade não é fundamental no processo, e sim o próprio estado mental (mindset). O empreendedor também foi descrito não como alguém necessariamente voltado para tecnologia, mas com um amplo conhecimento do domínio do negócio, seja ele formal ou informal. Segundo um dos entrevistados, "O empreendedor não é a pessoa que sabe tudo, é a pessoa que sabe capturar e aplicar o conhecimento dos outros".

Os comentários acerca de times também tiveram respostas parecidas, citando aspectos desejáveis nos profissionais, mas em um volume bem menor que na primeira parte da pergunta. Com relação a times, um ponto muito citado entre os entrevistados foi o da necessidade de ter perfis complementares dentro da equipe. Há inclusive quem afirme que o time é mais importante que o produto em si.

Os elementos mais citadas como essenciais para serem buscados em um time são: ter "gente boa" (com competência técnica e ao mesmo tempo ter valor como indivíduo), comprometimento com a empresa, diversidade, valores alinhados com os do fundador e do negócio, integração (a ponto de "agir como um cara só"), e disposição para exercer outras funções, que podem ser completamente alheias à sua descrição de cargo. Três dos entrevistados afirmaram explicitamente que há uma grande dificuldade em formar um time bom.

Ainda segundo as respostas obtidas na entrevista, o time perfeito (dream team) de uma startup seria composto por três pessoas : um membro técnico, que seria responsável pelo desenvolvimento do produto; um membro voltado para negócios, encarregado de vender o produto e conquistar novos mercados; e um gestor interno, alguém com conhecimentos de administração ou contabilidade, geralmente representado na figura do CEO, que teria a visão do produto e da empresa a longo prazo e trabalharia isso dia após dia. Pequenas variações desse padrão também foram citadas. Essa também foi uma constituição bastante observada dentre as sociedades às quais os entrevistados faziam parte, apesar de termos casos em que o empreendedor fundador cuidava do negócio sozinho.

"Não adianta cada um ser diferente, mas não conhecer nem um pouco da outra parte, porque em vez de ser um time viram 3 times de 1 pessoa". Essa frase, dita por um empreendedor, resume bem a questão da multidisciplinariedade: além de buscar profissionais complementares, é preciso que eles saibam trabalhar em equipe, exercendo 
funções além das suas e com foco no benefício da empresa.

Alguns pontos importantes sobre a relação dos sócios também foram destacados nas conversas. Essa é uma preocupação recorrente dos empreendedores, expressa em vários momentos das entrevistas. Um estudo da Fundação Dom Cabral [Fun14] mostra que cada sócio a partir do segundo aumenta em 1,24 vezes as chances de falha da empresa. Sobre esse assunto, um dos participantes afirma que muitos iniciantes tem a tendência a montar sua empresa com amigos ou conhecidos, o que torna a convivência diária no ambiente do negócio bastante difícil.

Outro fator de risco externado pelos participantes da entrevista é a ausência de um sócio especialista na constituição da empresa. Esse ponto se destacou pelos comentários de três membros de fundos de investimento ou anjos distintos. Acredita-se que, por terem uma visão mais externa do negócio, esse fator seja mais facilmente percebido por eles. Nas palavras de um deles, "Investir em empresas que têm a parte técnica bem desenvolvida é um melhor investimento, complementa mais". Outro participante também apontou que "Ter um sócio técnico é diferente de ter 3 sócios de negócio e terceirizar tudo", referindo-se a problemas muito comuns em startups de tecnologia, onde a saída do detentor do conhecimento gera sérios problemas.

\section{Motivação}

Quando questionados sobre motivação, metade dos entrevistados que responderam à pergunta afirmaram que o que leva o empreendedor a se arriscar com um novo negócio é um desejo de mudança, uma inconformação com o estado atual das coisas, e até mesmo uma "revolta pessoal". Outras razões fortemente citadas foram resolver um problema que alguém (incluindo ou não a ele mesmo) tenha, e o "sonho", a vontade de criar algo próprio.

O "brilho nos olhos" citado anteriormente nesta mesma seção também apareceu como uma forte motivação para empreendedores. Segundo os entrevistados, gostar do que faz e ter forte engajamento com a causa são estímulos comuns de serem encontrados em empreendedores. Outro fator que atua como combustível, na opinião dos participantes, é a necessidade de independência, seja ela financeira, seja a liberdade de poder tomar suas decisões sem ter que prestar contas a um chefe ou a algum departamento de uma empresa.

Outros motivos menos citados foram a filosofia de vida do profissional, explorar uma oportunidade de mercado, dinheiro e fazer história.

Algumas motivações, no entanto, foram questionadas. Dinheiro, o mais criticado deles, foi citado como sendo uma consequência, sendo menos importante para o profissional. Alguns empreendedores argumentaram que, tendo o dinheiro como motivação, as chances de desistência aumentam muito devido ao alto risco que a atividade enfrenta. A fama foi citada como um motivo bom por um entrevistado, e como motivo ruim por outro, em parte pelo falso glamour citado anteriormente. Outro incentivo apontado como ruim foi o de replicar negócios que funcionam em outras partes do mundo (copycats). Segundo um dos entrevistados, é muito melhor "identificar uma oportunidade de mercado e explorar, em vez de procurar algo pra empreender".

A seguir, serão explorados fatores que influenciam, positivamente ou não, o sucesso das startups de software, iniciando-se pela perspectiva tecnológica. 


\section{QP5 - Quais aspectos tecnológicos influenciam o sucesso das star- tups de software, e como? Em particular, qual é o papel executado por Orientação a Objetos, linguagens, arcabouços, padrões, mo- delos e arquiteturas? Qual é o papel do Software Livre?}

Um dos pontos mais discutidos nesta etapa foi a questão do custo. Com a rápida evolução da tecnologia, o custo para comprar e utilizar ferramentas de gerenciamento, armazenamento de dados, plataformas de desenvolvimento, dentre outras, tem se tornado cada vez mais acessível. Adicionalmente, o surgimento de plataformas como lojas de aplicativos para celulares (Google Play, App Store) e plataformas de distribuição de programas e jogos eletrônicos abriu portas para novos empreendedores digitais, que têm nessas plataformas canais para distribuições muito mais acessíveis.

Todas essas transformações fizeram com que a barreira de entrada para empresas de cunho tecnológico fosse reduzida significativamente. Serviços como computação em nuvem, elaboração e hospedagem de páginas, administração de redes, plataformas para testes, dentre outros, fazem com que o desenvolvimento de um protótipo usável, pronto para ser apresentado ao cliente, seja feito muito mais rapidamente. Essa é a visão de pouco mais de $1 / 3$ dos entrevistados de perfil técnico.

Quase a mesma quantidade de pessoas afirma, ao descrever sua empresa e como a parte tecnológica é gerenciada, que está vivendo uma etapa chamada aqui de transição de qualidade. São produtos que venceram a etapa inicial de criar um MVP ${ }^{4}$, e após conquistar uma base de usuários relativa, devem começar a se preocupar com design, estabilidade, escalabilidade do código e correção de bugs.

No entanto, essa transição muitas vezes acarreta em mudanças na estrutura do código da aplicação, o que quase com certeza pode gerar erros e instabilidades, temporárias ou não. E, considerando que startups quase o tempo todo lutam contra o tempo para entregar um produto que atenda às necessidades do seu clientes na hora certa, a velocidade de entrega de atualizações e novas versões nem sempre condiz com o tempo reservado para manutenções e melhorias nos códigos-fonte.

A expressão dívida técnica foi descrita pela primeira vez em 1992 por Ward Cunningham, programador que desenvolveu a primeira plataforma Wiki [SG11]. O termo, associado a dívidas financeiras recorrentes enfrentadas pelos seres humanos, refere-se ao esforço adicional ("juros") necessário para refazer um pedaço de código escrito às pressas e sem qualidade. Durante as entrevistas, algumas pessoas afirmaram claramente estarem preocupadas com dívidas técnicas, exatamente pela necessidade de balancear manutenções de código e lançamentos de novas funcionalidades. $\mathrm{O}$ equilíbrio entre essas duas, durante a análise dos resultados da entrevista, recebeu o nome trade-off.

Uma parte dos entrevistados, entretanto, afirmou não ter essa preocupação por confiar na maturidade do CTO ou da equipe técnica. Um dos participantes afirma que, sabendo o nível de conhecimento de sua equipe, essa questão não o aflige, pois os anos trabalhando no ramo trazem uma maturidade que por si só já reduz boa parte dos erros, como o conhecimento e a aplicação de boas práticas de código e a utilização de padrões de desenvolvimento. Nas palavras de um CTO, "As pessoas [de seu time] já passaram pela preocupação de aprender o que é bom software e hoje isso é natural".

\footnotetext{
${ }^{4}$ Acrônimo em inglês para mínimo produto viável, uma espécie de piloto testável de uma solução que atenda ao problema do usuário.
} 
Há também equipes que priorizam a resolução de bugs a qualquer custo. Segundo os membros dessas equipes, solucionar os problemas e garantir que o software esteja executando normalmente faz com que a inserção de novas funcionalidades ocorra mais facilmente e de uma maneira mais focada, sem outras atividades que concorram durante o desenvolvimento.

Quando questionados sobre ferramentas específicas, as respostas dos membros de startups foram variadas. A linguagem mais usada pelos desenvolvedores é Ruby, podendo ou não utilizar o arcabouço Rails. Outras linguagens que também foram citadas são Python (Django), C\# e Asp (.net), Java, Scala e PHP.

Com relação a ferramentas e metodologias de desenvolvimento, a presença de testes automatizados e de unidade foi bastante destacada [BK08]. Testes A/B, revisão de código, programação em pares, controle de versão e entrega contínua também foram citados como diferenciais para manter a qualidade do código. No entanto, cabe ressaltar que a eficiência dessas metodologias e ferramentas é bastante relativa, variando de projeto para projeto. Um número reduzido de entrevistados ressaltou que não é a linguagem, ou a plataforma, que faz a diferença, e sim sua utilização na resolução de um problema. Citando um deles, "A escolha da ferramenta em si não foi importante, e sim ter escolhido ferramentas boas que resolvem o problema".

O software livre também tem um papel fundamental no desenvolvimento de startups. Dos entrevistados com conhecimento técnico, quase a metade afirma que usa ferramentas de código aberto para desenvolver sua aplicação. Poucos rodam sobre plataformas abertas, e apenas um deles é distribuído como software livre. Infelizmente, o número de usuários não se reflete no número de contribuições; apenas duas pessoas garantiram já ter contribuído com código aberto, ou seja, ter enviado aos desenvolvedores do programa original alterações de código a serem incorporadas às novas versões. Esse dado não surpreende, considerando novamente a corrida contra o tempo enfrentada por startups diariamente.

Em relação aos motivos pela adoção (ou não) do software livre, a maior vantagem apontada pelos entrevistados é a diminuição do custo. Muitas vezes, software e plataformas proprietárias possuem despesas como licenças por usuário e/ou máquina, ou taxas a serem pagas para liberar novas funcionalidades que as versões gratuitas dos mesmos não apresentam. Esse custo pode parecer irrisório comparados com gastos como aluguel, pagamento de funcionários ou taxas administrativas, mas considerando os recursos altamente escassos que startups em geral enfrentam, o fato de poder usar uma ferramenta livremente pode fazer toda a diferença.

Ainda na comparação entre software livre e proprietário, afirmou-se durante as entrevistas que, em certos casos, o software livre chega a ser superior ao pago. Algumas dessas diferenças podem ser vistas em quesitos como estabilidade, quantidade de recursos, facilidade de customização e/ou adaptação, desempenho, etc.

Outro comentário a favor do uso de software livre em startups é a proximidade entre os dois. Alguns entrevistados atestaram que a maneira como o software livre é construído e mantido casa perfeitamente com a dinâmica de uma startup. Isso se dá, por exemplo, em fatores como trabalho remoto e gestão do tempo. Mais um ponto positivo para plataformas de código aberto é a quantidade de ferramentas existentes, o que evita que o desenvolvedor precise "reinventar a roda", poupando tempo e esforço ao utilizar um código que, na maioria dos casos, já foi utilizado, testado e melhorado por muitas pessoas.

Entretanto, o mesmo argumento usado para as ferramentas e linguagens de desenvolvimento também é aplicado aqui: estas são ferramentas que apenas contribuem para 
o progresso geral das startups, não sendo um fator crucial para alterar a trajetória da empresa. Nas palavras de outro entrevistado, "Não tem uma influência decisiva para o sucesso ou fracasso, o segredo está mais na aplicação que na tecnologia".

Dando prosseguimento à análise dos fatores que influenciam as startups em seu desenvolvimento, serão apresentados a seguir as opiniões acerca de elementos metodológicos.

\section{QP6 - Quais aspectos metodológicos influenciam o sucesso das startups de software, e como? Qual é o nível de adoção de métodos de desenvolvimento de negócios e de software bem conhecidos? Essa relação muda de acordo com o ciclo de vida da startup?}

A visão das metodologias de desenvolvimento de negócios utilizadas pelos entrevistados e difundidas no Brasil se mostrou bastante controversa no decorrer das entrevistas. Nessa discussão, destacam-se metodologias ágeis para o desenvolvimento de produtos e negócios, tais como Lean Startup, Quadro do Modelo de Negócios e Desenvolvimento de Cliente. Os conceitos sobre as metodologias foram tanto positivos como negativos.

Para os entrevistados que acreditam que essas metodologias são úteis, o principal argumento é de que essas técnicas ajudam o empresário a focar no que é realmente necessário. Quesitos como trabalhar primeiro o problema e depois a solução, testar hipóteses, apresentar suas ideias a pessoas, dentre outros, fazem com que se tenha uma visão mais clara do que deve ser desenvolvido, quem é o cliente e o que ele realmente deseja, trazendo como consequência uma diminuição do risco que permeia a startup. Esse também foi destacado como um fator positivo.

Vale ressaltar que a parte dos entrevistados que não concorda com essas metodologias não necessariamente é "contra" elas. Na maioria dos casos, essas pessoas acreditam que há maneiras melhores de conduzir seu negócio, tais como seguir a própria intuição ("acreditar e fazer"). Houve também argumentos de que essas metodologias ajudam, mas chegam a ser redundantes, pois quem realmente se preocupa com o sucesso de seu negócio deve pensar em coisas como atender a uma necessidade do cliente em caráter prioritário.

Um comentário realmente negativo acerca das metodologias de desenvolvimento de negócio é que elas não necessariamente funcionam em casos de inovação. Essas metodologias ajudam a diminuir riscos, aumentando a taxa de sobrevivência das startups, mas sem aumentar as possibilidades de criar um negócio milionário ou algo de imenso destaque, por exemplo. De certa forma, startups que utilizam essas metodologias podem estar caindo em uma "média", fazendo com que menos ideias disruptivas acabem despontando.

Outro ponto negativo que pode afetar essas metodologias é o fato de a maioria delas ser estadunidense, fazendo com que pontos peculiares que pertencem apenas à realidade brasileira estejam sendo ignorados sem que se dê conta disso e, a longo prazo, pode ser mais um fator de risco para essas startups. No entanto, esse fato não pode ser comprovado sem termos um conhecimento mais concreto acerca dos ecossistemas brasileiros e suas características.

As metodologias de desenvolvimento de software são usadas na maioria dos projetos. As mais citadas pelos membros técnicos das equipes foram Scrum e Programação Extrema (XP). Outras técnicas como Kanban (cartões de fluxo desenvolvidos na metodologia JustIn-Time [CPJ96]), Design Thinking [Bro08], PDCA [LMN+09] e Effectuation [Sar08] também foram citadas. Algumas ferramentas apontadas pelos participantes foram BurnUp Charts, Google Analytics e Trello. 


\subsection{Mapa do ecossistema de São Paulo}

Nesta seção, apresentam-se os mapas que representam os arcabouços conceituais dos ecossistema de startups estudados até agora pelo grupo, em especial o mapa do ecossistema de São Paulo.

De uma maneira geral, pode-se representar o arcabouço conceitual dos ecossistemas de startups de software através da Figura 4.2. Essa é uma visão simplificada, destacando apenas os elementos fundamentais presentes no ecossistema.

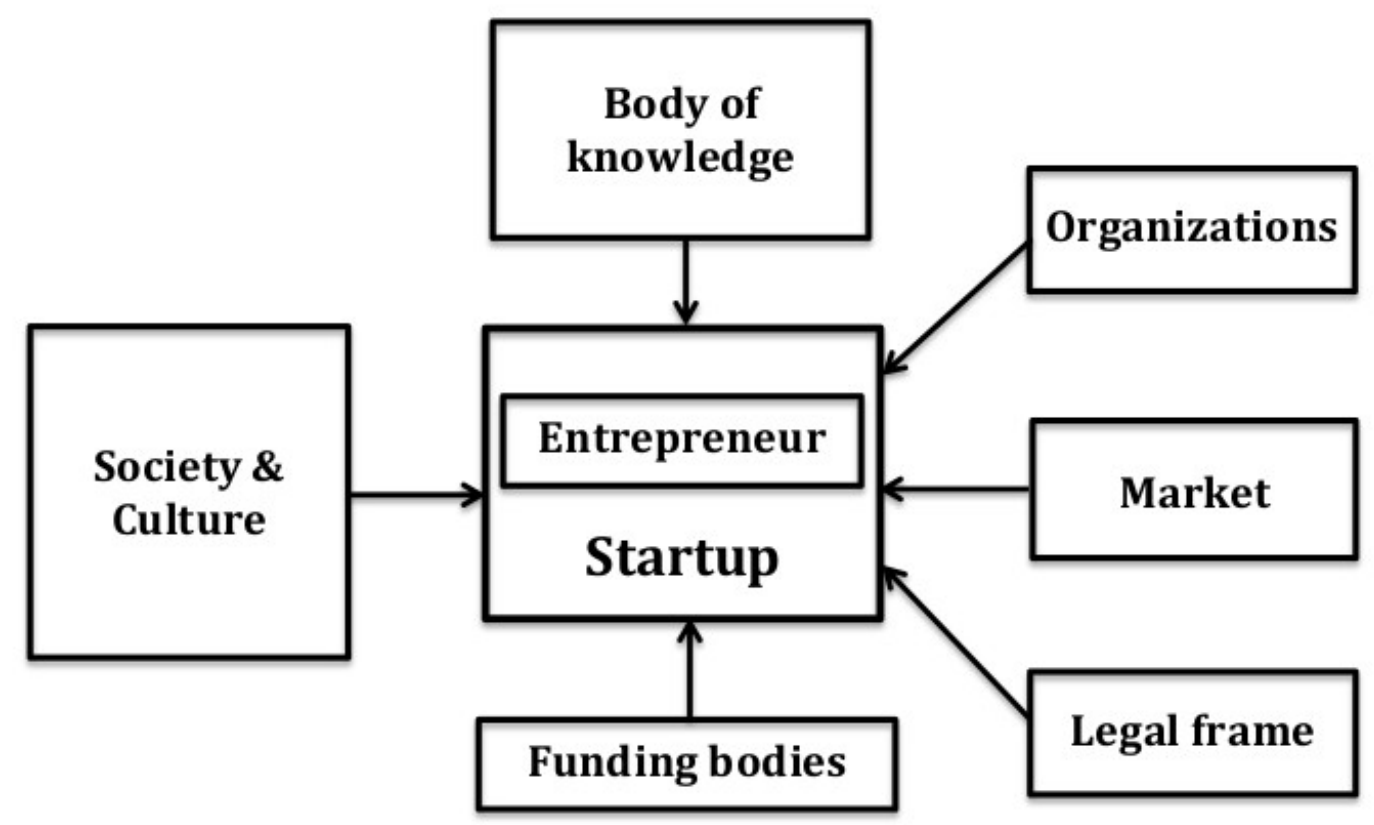

Figura 4.2: Arcabouço conceitual simplificado.

Além do mapa do ecossistema de São Paulo, a Figura 4.10 (página 56) apresenta o mapa conceitual do ecossistema de Israel, desenvolvido durante a pesquisa do grupo realizada em 2013. Ambos os mapas foram concebidos através da análise qualitativa combinada com elementos de Teoria Fundamentada em Dados para mapear os elementos fundamentais para ecossistemas de sucesso de acordo com as respostas das questões de pesquisa. Os relatórios técnicos correspondentes ao estudo de Israel estão disponíveis na página do grupo ${ }^{5}$.

O arcabouço conceitual de ecossistemas de software encontra-se na Figura 4.11, na página 58, para comparação. Ao contrário dos anteriores, este arcabouço foi elaborado logo após o de Israel, através da abstração de elementos específicos daquela região. O mapa conceitual foi novamente abstraído neste estudo, após a criação do mapa de São Paulo, originando o arcabouço simplificado da Figura 4.2.

\subsubsection{Análise do ecossistema de São Paulo}

O mapa do ecossistema de São Paulo pode ser visualizado na Figura 4.9, apresentada na página 54. Para facilitar a explanação textual dos elementos, faz-se aqui uma apresentação de cada um dos agentes do mapa, detalhados um a um em sentido horário, conforme a Figura 4.3. Não há uma ordem considerada correta para leitura ou análise do mapa; adotou-se esse sentido unicamente para facilitar a correlação de cada item.

\footnotetext{
${ }^{5}$ http://ccsl.ime.usp.br/startups/publications
} 
O tamanho de cada quadro na figura representa sua importância dentro do ecossistema. As linhas representam as relações entre os elementos interligados por elas, sendo que linhas em preto significam relações que foram observadas todo o tempo, ou quase todo tempo, e as pontilhadas, relações que foram observadas apenas em parte das vezes. A cada item citado, todas as suas relações também serão discutidas.

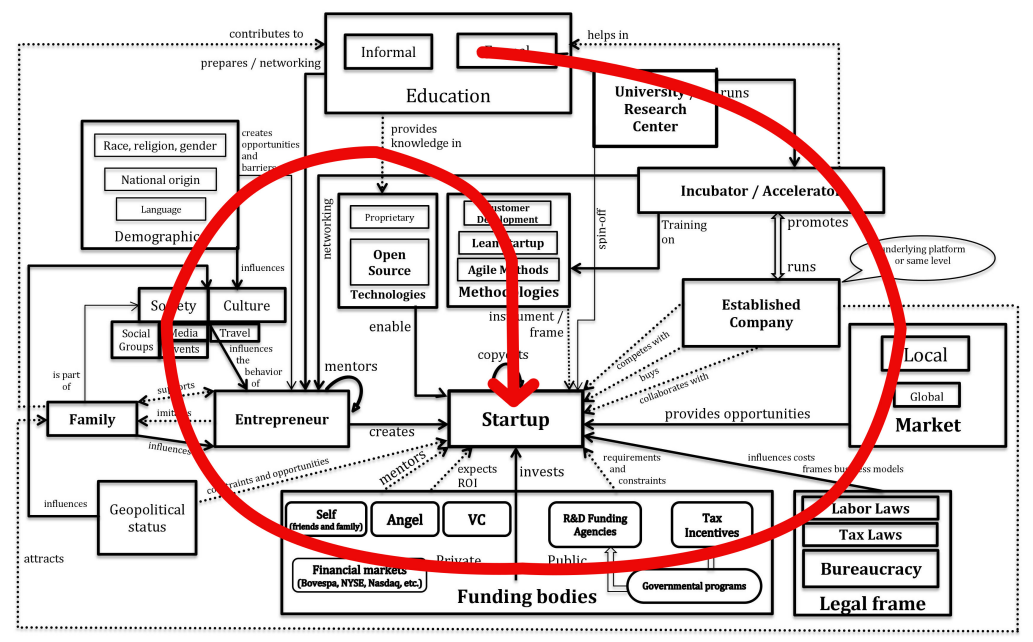

Figura 4.3: Sentido de leitura do mapa do ecossistema adotado para a análise atual.

Para facilitar a leitura, os parágrafos a seguir acompanham pequenos pedaços do mapa, nomeados como "eixos". Entretanto, devido à complexidade do mapa, foram excluídas das imagens as linhas que ligam a outros blocos mais distantes.

O primeiro eixo a ser analisado no mapa do ecossistema paulistano é o da educação, na parte superior central do mapa (Figura 4.4). Como visto na Seção 4.1, a educação formal e a informal ocupam juntas uma posição de importância na formação acadêmica do empreendedor. Em geral, a educação formal está fortemente ligada ao ensino superior, outros centros de pesquisas e escolas técnicas. A educação, além de preparar o empreendedor, também é uma importante ferramenta de networking, e oferece ao empreendedor o conhecimento de tecnologias que ele pode usar a seu favor na construção de sua startup.

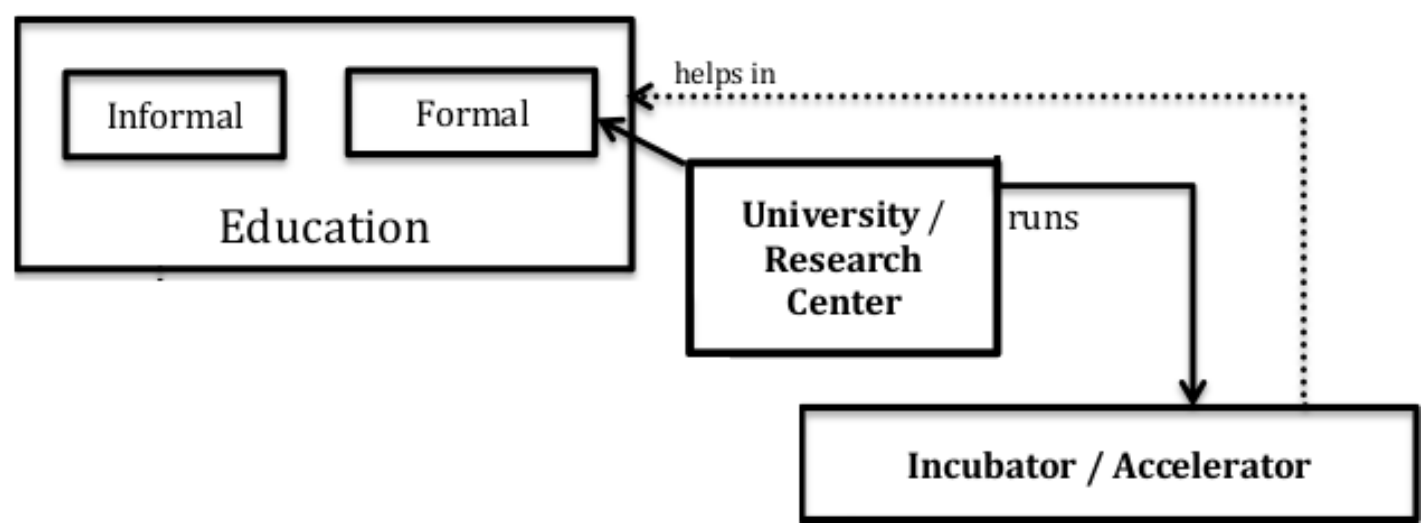

Figura 4.4: Primeiro eixo do mapa, contendo elementos educacionais

Outras instituições altamente importantes para a formação educacional do empreendedor são as incubadoras e aceleradoras, que no caso do ecossistema brasileiro tem uma relação direta com o quadro de educação. Além de contribuir para a educação formal, essas instituições também contribuem para o ecossistema provendo treinamentos em metodologias ágeis e de desenvolvimento de produtos, e oferecendo canais e eventos de 
networking para os participantes de seus programas. Essa é outra relação de destaque. A gestão de incubadoras e/ou aceleradoras por parte de universidades se vê presente em São Paulo, por exemplo, através do CIETEC, da USP.

As universidades também podem gerar spin-offs, que são empresas novas provenientes de outras empresas ou de centros universitários, construídas para dar mais foco a um determinado negócio ou aspecto dele.

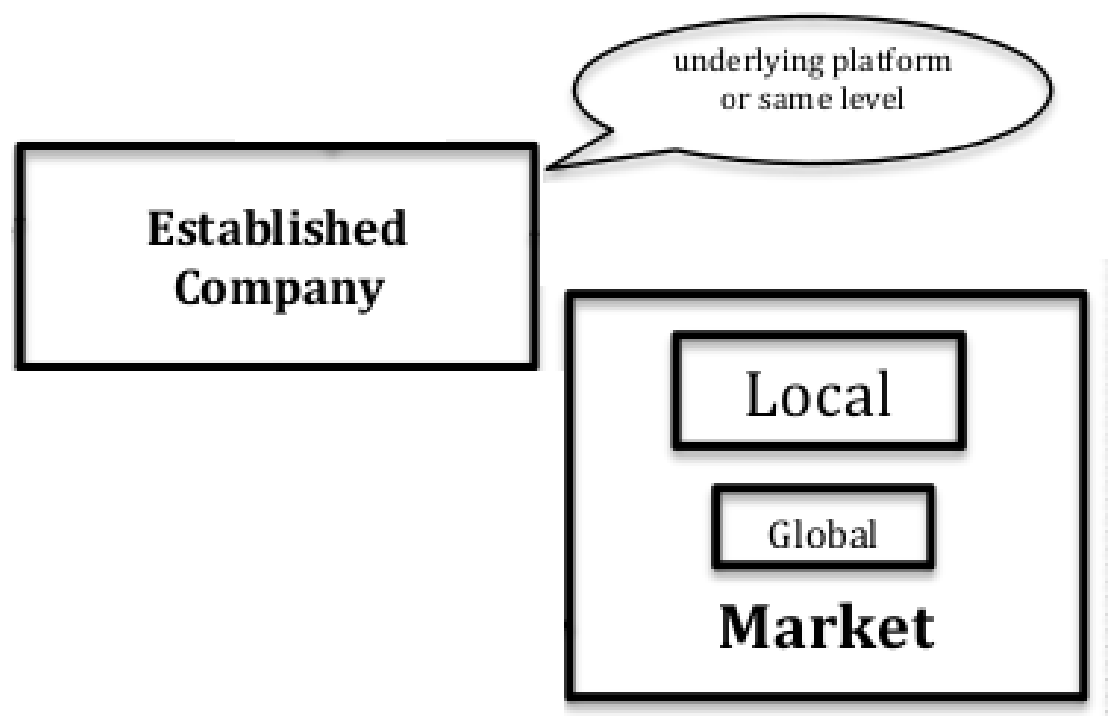

Figura 4.5: Segundo eixo, empresas

O segundo eixo, ilustrado na Figura 4.5 e localizado um pouco mais abaixo do primeiro no mapa completo, é constituído pelas empresas e pelo mercado. Há uma relação direta entre as empresas (Established companies) e as incubadoras e aceleradoras, sendo que estas podem ser mantidas e geridas por empresas, como é o caso da Wayra no Brasil, ou receber investimentos e firmar parcerias. Da mesma forma, incubadoras e aceleradoras podem promover empresas parceiras.

A relação entre empresas e startups é extremamente densa. Ao mesmo tempo em que concorrem uma com a outra, empresas podem contribuir com as startups, através da oferta de conhecimento, de parcerias estratégicas ou de investimentos financeiros, ou até mesmo adquiri-las por completo. Uma relação também exclusiva do ecossistema de São Paulo descoberta nas entrevistas é que grandes empresas, ou regiões com grande abundância delas, costumam atrair os empreendedores e suas famílias, através de (1) ofertas de trabalho para novos funcionários ou (2) abertura de filiais e transferências de funcionários atuais.

Ligeiramente à direita das empresas está o mercado. É ele quem oferece oportunidades para que a startups explorem. Em São Paulo, o mercado é majoritariamente local ou nacional, com algumas poucas startups focando no mercado internacional. Isso se repete também em outras cidades brasileiras, posto que menos de $1 \%$ do total das empresas são exportadoras [End14]. Esse é o caso totalmente oposto de Israel, onde o mercado global é muito mais focado, e há a presença de um mercado remoto, onde startups abertas no país operam exclusivamente no exterior.

O próximo quadro a ser analisado, no terceiro eixo, é o de legislação, disponível na Figura 4.6. As regras tributárias e legislativas de cada ecossistema influenciam os custos das startups e moldam os modelos de negócios. No ecossistema de São Paulo, além desses fatores terem um peso muito maior devido ao grande número de impostos e a alta burocracia, o elemento "patentes e propriedade intelectual" não aparece, em comparação 


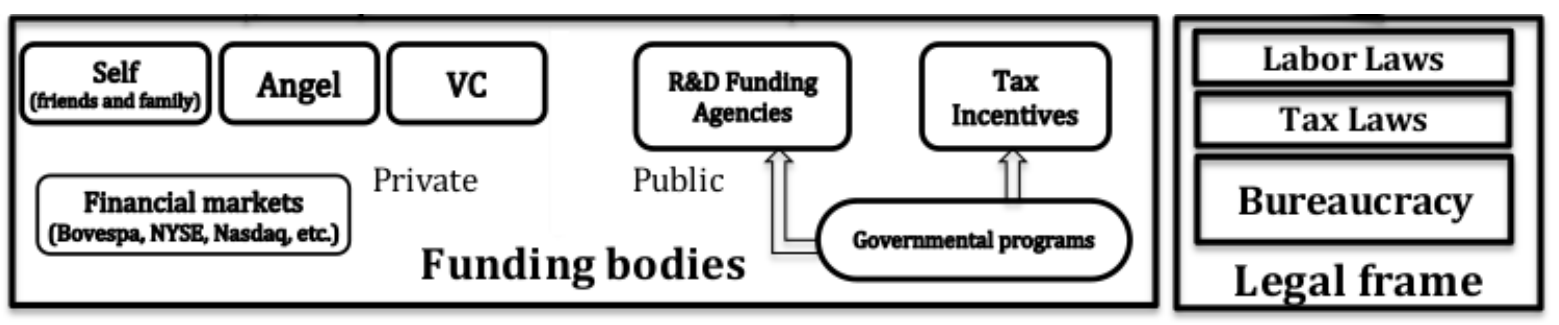

Figura 4.6: Terceiro eixo, representando os quadros legislativo e de financiamento

com Israel.

No extremo inferior do mapa estão os organismos de financiamento. Além de investirem diretamente na startup, certos elementos também oferecem outras vantagens ou impõem condições específicas. Do lado esquerdo do quadro, estão os investimentos privados, tais como os anjos, os fundos de investimento de risco, e os próprios empreendedores e sua rede de contatos. Esses investidores, além de dinheiro, oferecem mentorias, e em boa parte dos casos (especialmente anjos e VCs), esperam obter um retorno do dinheiro investido.

Do lado direito, o financiamento público hoje é representado em sua maioria por programas de governo. Esses programas podem ser constituídos de políticas fiscais favoráveis ao empreendedorismo, ou através de investimento financeiro vindo de agências de pesquisa e desenvolvimento. Essas agências, no entanto, apresentam suas próprias regras e condições para o recebimento e aplicação do dinheiro ofertado, como é o caso do programa PIPE.

Nesse quadro também estão presentes os mercados financeiros. Apesar de as poucas empresas brasileiras com ações na bolsa estarem em sua maioria concentradas na Bovespa (Bolsa de Valores de São Paulo), também há empresas brasileiras operando na NYSE (Bolsa de Valores de Nova Iorque), na NASDAQ, dentre outras.

O quarto eixo, exibido na Figura 4.7, corresponde aos empreendedores e os fatores socioeconômicos aos quais estão submetidos. Startups também sofrem restrições apresentadas por políticas externas e relações internacionais. Essas condições podem tanto ser positivas, oferecendo oportunidades de negócio que podem ser exploradas, tanto negativas, criando restrições de mercado. O cenário geopolítico também influencia empreendedores, embora de forma indireta.

A família do empreendedor tem uma função importante no ecossistema. Além de influenciar o empreendedor, ela oferece suporte, tanto financeiro quanto emocional, e se torna um modelo para o empreendedor, que muitas vezes imita familiares que abriram negócios próprios ou replica conceitos de intraempreendedorismo (empreendedorismo dentro de uma organização já existente [AH01]) que aprendeu no seio do lar. Em São Paulo, constatou-se que a família também contribui fortemente na educação informal, através de conselhos ou da troca de experiências entre gerações.

O empreendedor também é influenciado por outros empreendedores, que contribuem para o ecossistema passando seu conhecimento a outros na forma de mentorias, e por aspectos socioculturais. No ecossistema de São Paulo, evidenciou-se o impacto causado por grupos sociais de empreendedorismo, tais como associações acadêmicas, eventos, a mídia e até mesmo viagens internacionais para outros ecossistemas mais consolidados. Outros aspectos demográficos, como etnia, religião, gênero, nacionalidade e idioma também influenciam o empreendedor indiretamente através da cultura, e podem oferecer oportunidades ou apresentar barreiras em sua jornada.

O quinto e último eixo do mapa, em destaque na Figura 4.8, corresponde à startup e 


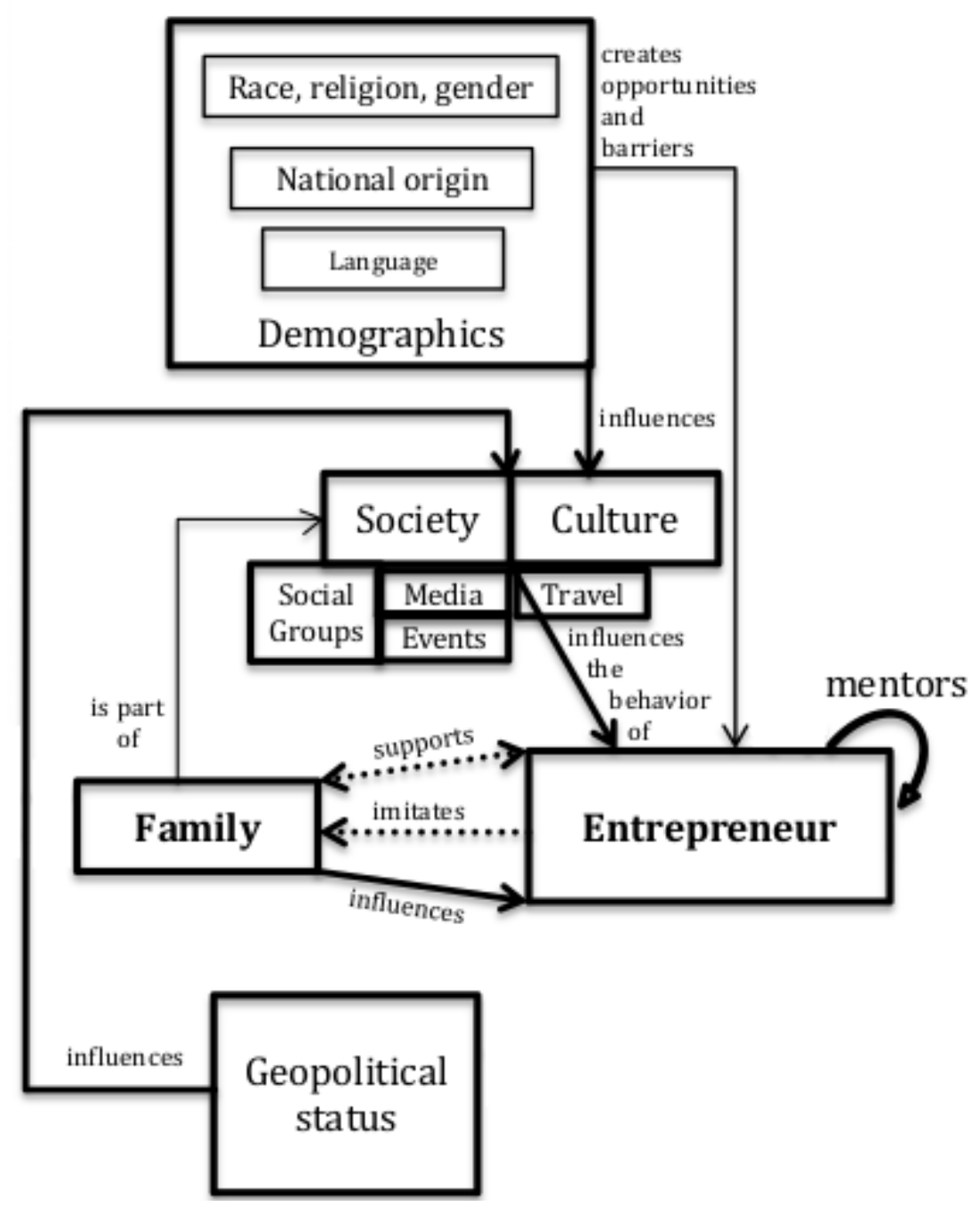

Figura 4.7: Quarto eixo, retratando o empreendedor e suas influências

suas bases.

As tecnologias aprendidas pelo empreendedor oferecem condições para a criação da startup. A maioria das tecnologias utilizadas por empreendedores é ou está relacionada a software livre, por motivos já detalhados na página 44. As metodologias também são um importante instrumento para a criação do negócio, pois fornecem instrumentos para a criação do produto e a gestão do desenvolvimento e do negócio. No entanto, no ecossistema brasileiro detectou-se uma tendência de "enquadramento", onde as metodologias atuais são positivas no sentido de que diminuem a possibilidade de fracasso, mas também podem impedir grandes sucessos disruptivos.

O elemento final do mapa é a startup, criada pelo empreendedor. Todos os elementos estão ligados a ela, direta ou indiretamente. Startups também podem se assemelhar em termos de modelo de negócio, gerando copycats, e o ecossistema de São Paulo apresenta uma grande tendência a esses casos.

Visualmente, o mapa do ecossistema de São Paulo apresenta muito mais conexões, quando comparado com o de Israel. Isso ocorre pois, além de este trabalho ter tido como ponto de partida o estudo feito em Israel, as entrevistas realizadas em São Paulo cobriram mais temas do que as realizadas no outro estudo.

Tendo apresentado uma visualização compreensiva do ecossistema de startups de software da cidade de São Paulo, concluímos esta análise com algumas considerações acerca 


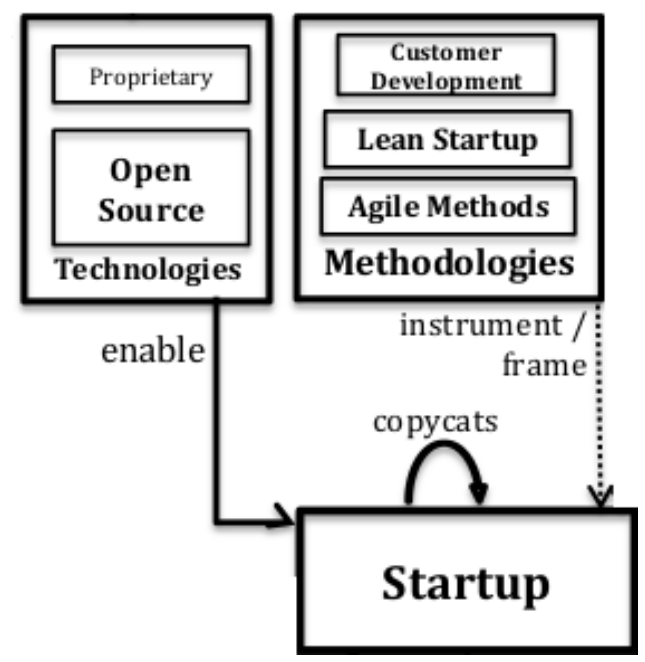

Figura 4.8: Quinto eixo, correspondente à startup, suas tecnologias e metodologias

do que pode ser feito para contribuir com sua melhora. Estas considerações serão detalhadas no próximo capítulo. 


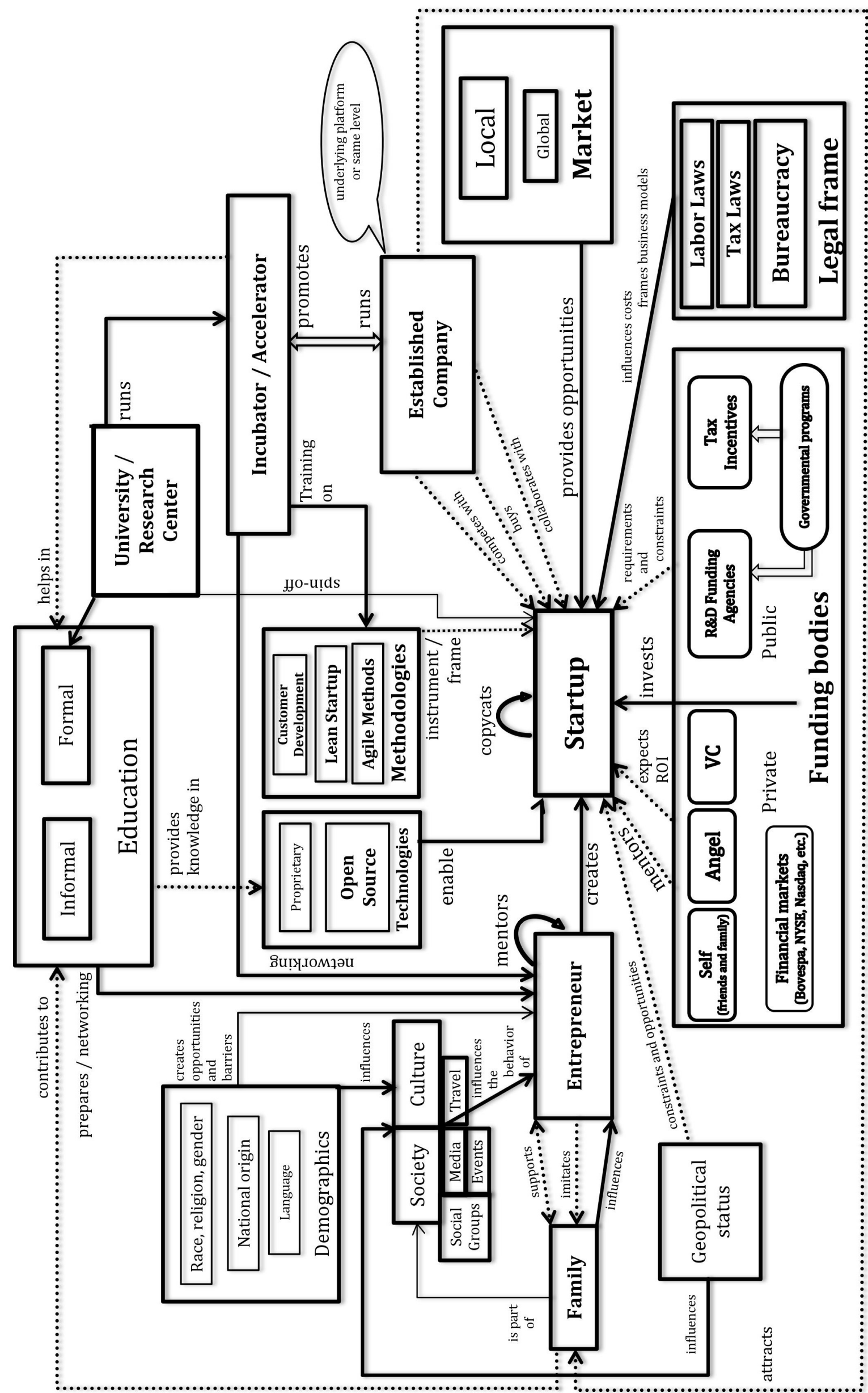




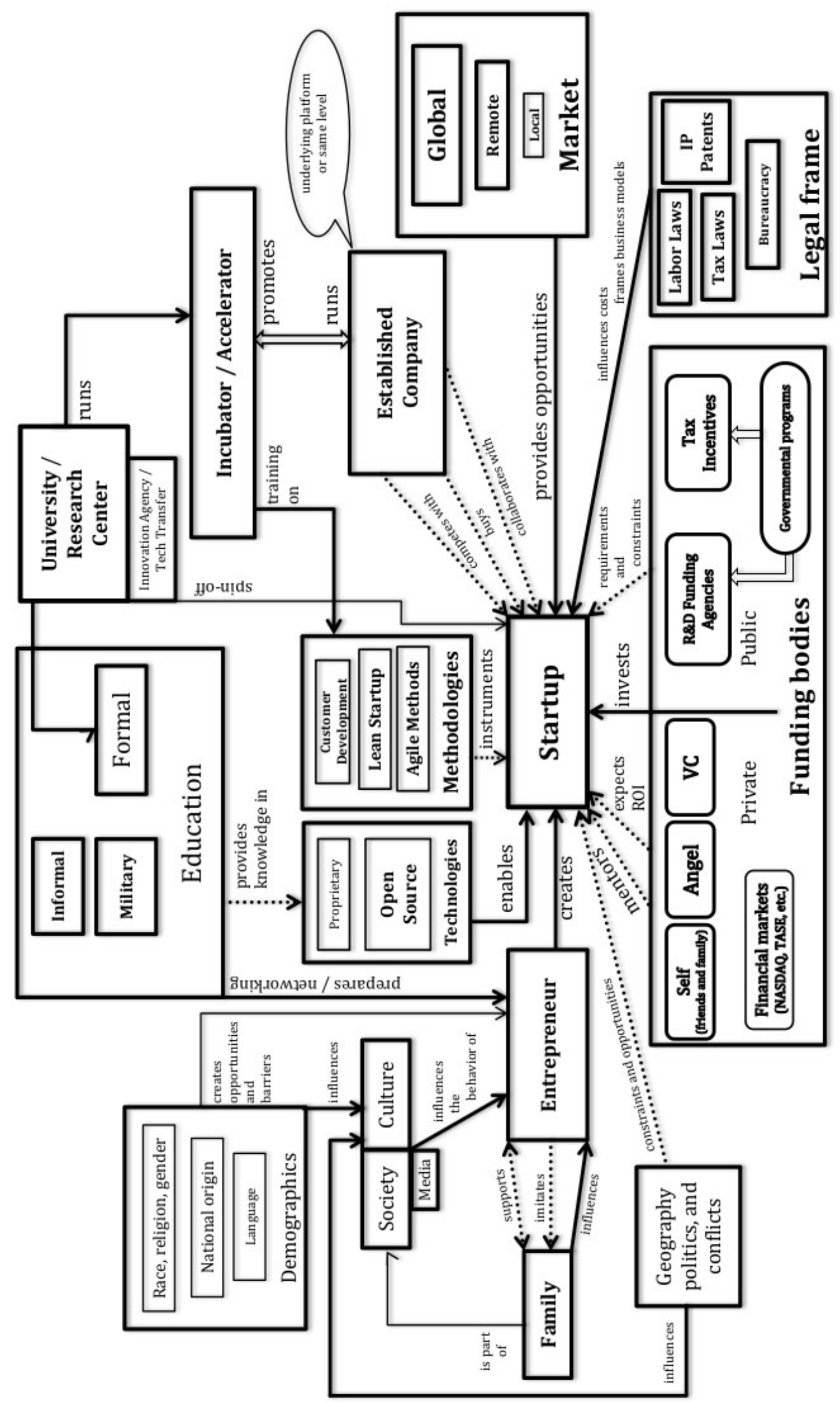

Figura 4.10: Mapa do Ecossistema de Startups de Software de Israel (2013) [KCHY14]. 


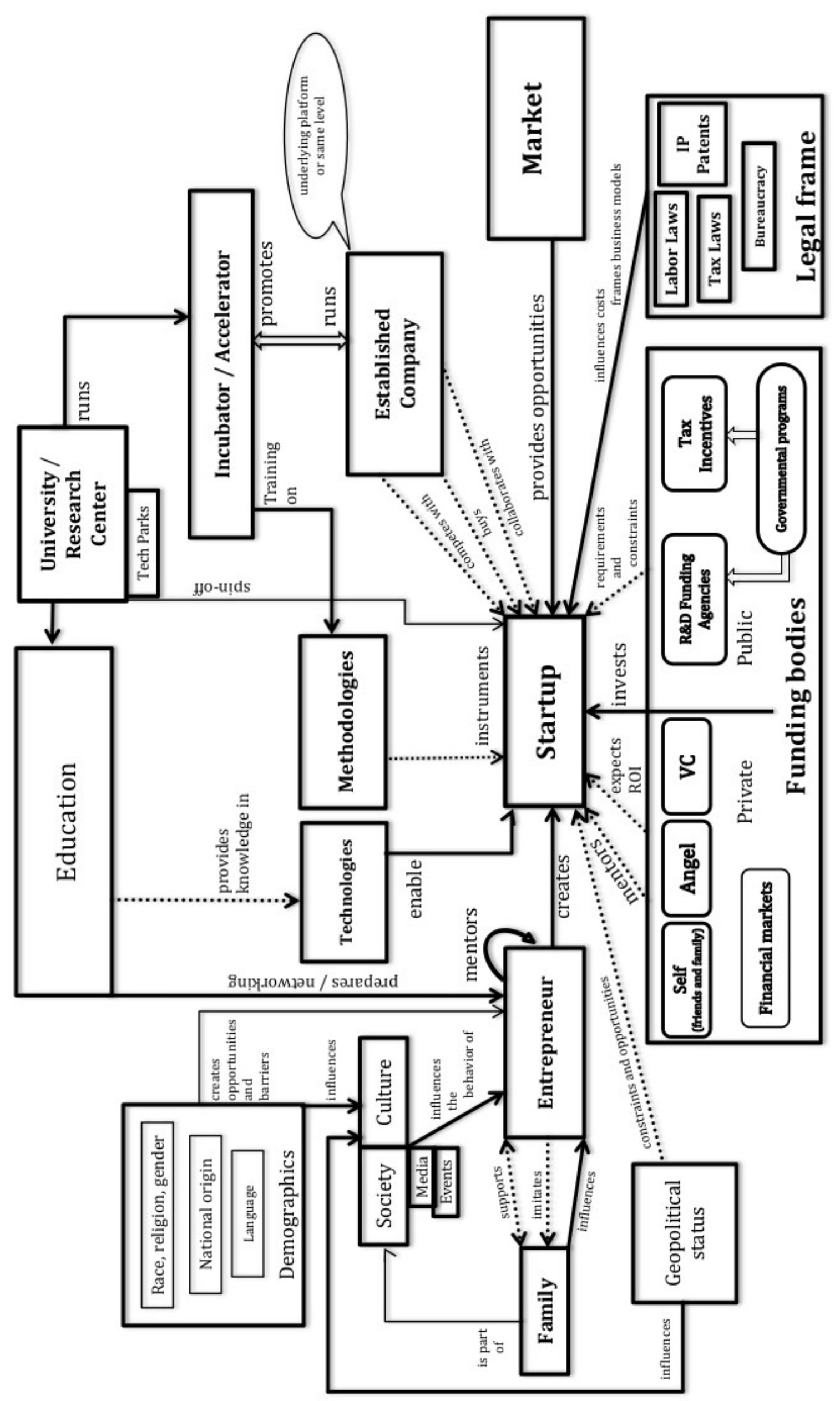

Figura 4.11: Arcabouço conceitual de ecossistemas de startups. 


\section{Capítulo 5}

\section{Conclusões}

Neste capítulo final, apresentam-se algumas conclusões acerca das análises apresentadas anteriormente neste documento e discute-se possíveis ações para cada aspecto que precisa ser melhorado.

\subsection{Contexto socioeconômico atual do ecossistema}

O Brasil ainda possui poucos programas de incentivo a startups, sendo restritos a programas de aceleração, como o Startup Brasil; poucos programas de mentoria, como o InovAtiva; e alguns programas de financiamento público como o PIPE da FAPESP.

Apesar dessas iniciativas serem muito bem-vindas, ainda são necessárias importantes mudanças no marco regulatório das empresas. Dos entrevistados, boa parte afirma que as tributações excessivas são um problema para o empreendedor, juntamente com a grande burocracia e a falta de uma legislação voltada para empreendedorismo.

O estudo da Endeavor realizado em 14 cidades brasileiras [End14] coloca São Paulo no $12^{\circ}$ lugar no quesito Ambiente Regulatório (figura 5.1). Dois dos motivos são os altos impostos e a alta taxa de congestionamento de processos nos tribunais de justiça (63,60\%, a terceira mais alta). Segundo o estudo, que apresenta Goiânia (GO) como a melhor cidade brasileira no último item, São Paulo tem feito grandes esforços para a unificação de processos e a redução do tempo de abertura de empresas, mas essas medidas devem ser replicadas para outros quesitos, como a velocidade na aprovação de projetos arquitetônicos. Essas medidas são importantes, mas não necessariamente afetam empresas de software, que sofrem mais com dificuldades relacionadas ao ambiente virtual. Um exemplo disso é o alto preço da computação em nuvem no Brasil, especialmente no caso de serviços estrangeiros, agravado ainda mais pela desvalorização da moeda brasileira em relação ao dólar.

Esses dados mostram que se fazem necessárias (1) mudanças no arcabouço jurídico para facilitar a abertura e fechamento de empresas e garantir a participação segura de investidores em empresas nascentes e (2) melhorias fiscais simplificando o pagamento de impostos e diminuindo a carga tributária.

Há também uma lacuna cultural que deve ser vencida por parte dos empreendedores. Ao contrário de outros ecossistemas, "O brasileiro ainda tende a fazer negócios isoladamente, com pouca colaboração e conhecimento entre empresas", afirma um representante do governo. Outro entrevistado, um experiente empreendedor já com saídas, culpa a "cultura do cafezinho": a necessidade de conversar cara-a-cara, de ter duas ou três reuniões antes de uma determinada ação, que em alguns casos pode ser vista como desperdício de tempo. Considera-se hoje um desafio de qualquer ecossistema promover a integra- 


\begin{tabular}{|c|c|c|c|c|c|c|}
\hline Cidade & $\begin{array}{c}\text { Índice } \\
\text { Tempo de } \\
\text { Processos }\end{array}$ & $\begin{array}{l}\text { Tempo para } \\
\text { abrir um } \\
\text { negócio } \\
\text { (em dias) }\end{array}$ & $\begin{array}{l}\text { Tempo para } \\
\text { obter energia } \\
\text { elétrica } \\
\text { (em dias) }\end{array}$ & $\begin{array}{l}\text { Tempo para } \\
\text { aprovação de } \\
\text { projetos ar- } \\
\text { quitetônicos } \\
\text { (em dias) }\end{array}$ & $\begin{array}{l}\text { Tempo para } \\
\text { obtenção } \\
\text { de registros } \\
\text { imobiliários } \\
\text { (em dias) }\end{array}$ & $\begin{array}{l}\text { Taxa de } \\
\text { congestio- } \\
\text { namento em } \\
\text { tribunais }\left(^{*}\right)\end{array}$ \\
\hline Goiânia & 7.62 & 32 & 15 & 60 & 15 & $57.98 \%$ \\
\hline Belém & 7.38 & 55 & 5 & 90 & 71 & $51.38 \%$ \\
\hline Manaus & 7.11 & 51 & 5 & 90 & 36 & $58.08 \%$ \\
\hline Brasília & 6.40 & 75 & 18 & 60 & 90 & $57.19 \%$ \\
\hline Florianópolis & 6.23 & 80 & 25 & 90 & 26 & $60.53 \%$ \\
\hline Curitiba & 6.19 & 60 & 5 & 90 & 65 & $62.77 \%$ \\
\hline Belo Horizonte & 6.16 & 55 & 20 & 90 & 75 & $58.64 \%$ \\
\hline Vitória & 6.05 & 74 & 8.5 & 90 & 70 & $61.63 \%$ \\
\hline Salvador & 5.78 & 68 & 30 & 45 & 65 & $65.02 \%$ \\
\hline Fortaleza & 5.67 & 75 & 5 & 90 & 150 & $57.07 \%$ \\
\hline Recife & 5.57 & 68 & 7 & 120 & 90 & $61.27 \%$ \\
\hline São Paulo & 5.29 & 36 & 30 & 120 & 63 & $63.60 \%$ \\
\hline Rio de Janeiro & 4.49 & 100 & 60 & 90 & 52 & $63.96 \%$ \\
\hline \multirow[t]{3}{*}{ Porto Alegre } & 4.04 & 245 & 17.5 & 180 & 53 & $57.85 \%$ \\
\hline & Fonte & SEDI & SEDI & SEDI & SEDI & $\mathrm{CNJ}$ \\
\hline & Ano & 2014 & 2014 & 2014 & 2014 & 2013 \\
\hline
\end{tabular}

Figura 5.1: Índice de cidades empreendedoras segundo o ambiente regulatório. ${ }^{1}$

ção das pessoas de forma saudável e eficiente, evitando ruído desnecessário (ex.: eventos de empreendedorismo que não agregam valor ao profissional) e propiciando a troca de conhecimento.

Em relação à cidade de São Paulo, um ponto que desestimula a atividade empreendedora apresentado pelos entrevistados é o alto custo de vida de São Paulo. Isso impacta diretamente em fatores como preço de imóveis, salário pago a funcionarios, dentre outros. A falta de mobilidade urbana também afeta os empreendedores, que perdem um tempo precioso em atividades simples que envolvem locomoção. Na opinião de um jovem empreendedor, "se a cidade ficar muito ruim, espanta as melhores cabeças a longo prazo".

\subsubsection{Financiamento}

Apesar de São Paulo concentrar todas as instituições necessárias para dar suporte a startups, sua atuação ainda está muito limitada. Quase 1/4 dos entrevistados afirma que os elementos de apoio a startups ainda são muito fracos e/ou estão desconectados. Um exemplo disso são os fundos de investimento: segundo a Compass.co, há uma forte presença de investimentos de risco de fundos na capital, mas a maioria deles ainda está nas suas rodadas de investimento iniciais, ainda sem casos de sucesso. O êxito dessas startups é o que trará lucro para o fundo e realimentará o ecossistema [Com15].

Para que isso aconteça, é necessário aumentar a força dos fundos, através de opções que

\footnotetext{
${ }^{1}$ Extraído de: Endeavor. "Índice de Cidades Empreendedoras Brasil 2014”. Disponível em: http://info. endeavor.org.br/ice2014, último acesso em 11/09/2015.
} 
facilitem o investimento sem estender ao investidor perdas e responsabilidades jurídicas que não lhe cabem. Considera-se hoje que o ecossistema possui suficientes opções de fundos, mas a entrada de outros também pode melhorar esse quadro.

Outra queixa muito forte dos empreendedores é a falta de capital semente, que acaba vindo geralmente do próprio empreendedor ou de pessoas próximas a ele: os chamados FFF (family, friends and fools - numa referência aos "tolos" que acreditam na ideia). Nem todo aspirante a empreendedor possui pessoas para o qual ele possa pedir recursos, e hoje no Brasil não é comum que fundos de investimento façam aportes de nível inicial.

Novamente, a solução passa pelo marco regulatório. A recente formalização da figura do investidor-anjo em termos legislativos é um dos passos que podem contribuir para isso ${ }^{2}$. A regulamentação de modalidades de investimento não tradicionais, como por exemplo o crowdfunding, e até a concessão de benefícios fiscais são outras políticas que devem ser consideradas num futuro próximo.

A própria FINEP tem trabalhado para tentar preencher essa lacuna. Em outubro de 2015, a empresa pública anunciou uma linha de investimento para empresas de base tecnológica, onde pretende atuar com presença societária dentro da empresa, juntamente aos investidores anjo. O principal objetivo do programa é evitar que empresas na fase final de desenvolvimento do produto acabem falhando por falta de recursos para lançar a solução ao mercado ${ }^{3}$.

Uma falha apontada pelos entrevistados é a da necessidade de lucro. No Brasil, as startups e empresas são fortemente induzidas por investidores a trazer o retorno do investimento o mais rápido possível. A pequena taxa de saída desses investidores faz com que os fundos brasileiros não tenham a mesma estabilidade que em outros países, onde uma startup consegue passar vários anos investindo em pesquisa ou no desenvolvimento do produto e sendo mantida por aportes monetários. Acredita-se que esse problema se tornará menos grave se forem concretizados maiores índices de saída de startups e melhora do marco regulatório para investimentos.

Nesse caso, a pressão pode ter como causa a aversão ao risco, que ainda é muito presente no ecossistema brasileiro. Uma medida que poderia amenizar isso é aumentar a proteção ao investidor, através de mudanças na legislação, fazendo com que mais investimentos de grande porte ocorram em startups [ACNC13].

\subsubsection{Educação}

Com relação à educação, a Endeavor afirma que o principal foco de melhoria que o estado de São Paulo precisa é de facilitar o acesso dos cidadãos ao ensino superior. Mesmo tendo universidades de ponta, apenas $24 \%$ da população paulista concluiu uma faculdade. O acesso à educação não é um problema exclusivo desse estado, pelo contrário; afeta intensamente todo o país, e antes de mais nada deve-se trabalhar políticas públicas de inclusão social.

No meio tecnológico, há uma grande queixa de membros e CEOs de startups em relação à dificuldade de encontrar bons profissionais de TI, especialmente CTOs. Esse é um gargalo bem específico do ecossistema de startups de software. Para resolver esse problema, as universidades da região deveriam formar mais bachareis, mestres e doutores em Ciência e Engenharia da Computação e Sistemas de Informação, incluindo mais profissionais nas áreas de desenvolvimento de software e Big Data. Adicionalmente, cur-

\footnotetext{
${ }^{2}$ http://startupbrasil.org.br/startups-podem-ter-mais-investimentos-com-mudanca-no-supersimples/, último acesso em 25/09/2015.

${ }^{3}$ http://www.finep.gov.br/noticias/todas-noticias/5097, último acesso em 28/10/2015.
} 
sos livres de programação deveriam ser oferecidos desde o Ensino Médio até a Educação Continuada de forma a aumentar o número de programadores disponíveis no ecossistema.

Uma opção que pode representar um grande diferencial na formação de mais empreendedores é a educação online. Essa modalidade de estudo apresenta vantagens como flexibilidade, modularização e alta possibilidade de customização, além de permitir, em alguns tipos de cursos, que o próprio aluno monte sua rotina de estudos. Cursos online específicos podem ser usados tanto para atrair mais pessoas para áreas de tecnologia, despertando o interesse em se especializar nesse ramo, ou, no caso dos empreendedores, complementar a formação provendo habilidades de negócio específicas, sem a necessidade de passar vários anos em um curso ou uma faculdade completos.

Uma dessas iniciativas é o curso O Empreendedorismo e as Competências do Empreendedor ${ }^{4}$, oferecido pela UNICAMP através da plataforma de cursos à distância Coursera. Segundo o professor responsável pelo curso, o professor Paulo Lemos, em seis meses o curso já formou 500 alunos.

Elementos comuns ao empreendedor, tais como correr riscos, o pensamento crítico, a criatividade e a execução de projetos também devem ser estimulados sempre que possível. Ao comentar sobre educação, boa parte dos entrevistados acredita que disciplinas nãoobrigatórias devem estar disponíveis em todas as etapas educacionais. Mas o ensino da cultura empreendedora não se dá apenas com disciplinas optativas na universidade. Isso pode ser feito tanto com ações mais específicas do ramo, como: competições de pitches ou planos de negócio; hackathons ou concursos para a solução de problemas específicos; startup weekends ou similares; e eventos de networking, quanto com dinâmicas mais focadas no desenvolvimento pessoal, como atividades interdisciplinares ou concursos de invenções.

Outras medidas que não sejam necessariamente focadas no empreendedorismo podem trazer contribuições significativas, através do incentivo à inovação e à interdisciplinariedade. A criação de disciplinas, cursos e até mesmo espaços de integração que propiciem o contato de estudantes de diversas áreas em torno do desenvolvimento de projetos faz com que novas ideias surjam, além de estabelecer um chance de vínculo maior entre pessoas que criam novas ideias e pessoas com conhecimento técnico para implementá-las.

Certas carreiras acadêmicas têm uma propensão maior ao empreendedorismo, e não necessariamente recebem algum tipo de treinamento para isso. É o caso de alunos de ciências biológicas (ex.: fonoaudiologia, veterinária, psicologia, etc.), e outros ramos como advocacia, música e arquitetura, por exemplo. Esses profissionais costumam muitas vezes ter em sua carreira a opção de abrir consultórios ou escritórios próprios, fazendo com que uma educação para o empreendedorismo se torne um diferencial. Assim, a universidade pode ajudar a seus alunos a lidar com outros aspectos do negócio que não necessariamente estão ligados à sua especialização, tais como contabilidade e formalização jurídica. Esse não é o foco dessa dissertação, mas foi um ponto ressaltado por uma pequena parte dos entrevistados.

Adicionalmente, o empreendedorismo ensina lições importantíssimas como gestão pessoal, inovação, apresentação, interdisciplinariedade e muitas outras. O próprio mercado hoje exige um profissional que saiba empreender dentro do seu próprio posto de trabalho, com proatividade, oferecendo suas opiniões e sabendo participar nas decisões da empresa. Se essas habilidades não começarem a ser cultivadas nos estudantes, a educação formal apenas se tornará mais defasada e tenderá a ser descartada.

Naturalmente, mesmo com uma educação que abrace o empreendedorismo, nem todos seguirão essa carreira, seja por não possuir vocação pessoal ou por puro desinteresse. Mas é fundamental que essa opção de carreira passe a ser visível para todos, em todos os níveis

\footnotetext{
${ }^{4}$ https://www.coursera.org/learn/empreendedorismo/
} 
escolares, de forma que cada indivíduo possa fazer sua escolha livremente.

\section{Colaboração entre universidade e empresas}

A aplicação da inovação gerada nas universidades é um fator crítico para o aumento de negócios de alto potencial de impacto. É fundamental quebrar os preconceitos do mundo acadêmico de Computação contra o mundo empresarial, e vice-versa. Sem uma proximidade maior entre indústria e academia e o apoio ao empreendedorismo dentro da pós-graduação, um sem-número de trabalhos de conclusão de curso, dissertações e teses com grande potencial econômico pode estar sendo desperdiçado em arquivos e gavetas.

Uma das maneiras de reverter esse quadro é a criação de um escritório para divulgação de pesquisa científica, voltado para a transformação de pesquisa em novos negócios. Isso pode se dar tanto pelos alunos iniciando empresas, ou "vendendo" suas pesquisas para empresas ou startups que façam a implementação do conhecimento em um produto viável. Essa sugestão vem de um jovem empreendedor técnico, entrevistado em nossa pesquisa, que viu algo semelhante na universidade de Tel-Aviv.

Um ponto que muitas vezes divide opiniões é o da entrada de capital privado nas universidades públicas. Embora esse seja um modelo comum em todos os países, como Estados Unidos, Japão, Reino Unido e Israel, no Brasil a entrada desse tipo de investimento é vista como negativa por uma certa parcela da comunidade acadêmica. A vantagem desse modelo é o alívio aos cofres públicos. O dinheiro destinado às universidades públicas em relação ao PIB é insuficiente [Sgu05], e recentemente tem diminuído à medida que novos cortes são anunciados ${ }^{5}$. O investimento privado poderia ser uma solução no apoio a certas linhas de pesquisa e inovação.

Entretanto, alguns dos argumentos que sustentam a não-adoção desse modelo no país são uma possível perda de independência das instituições de ensino em termos da escolha de temas de pesquisa e questões ideológicas acerca da detenção do conhecimento por parte do poder público. Embora seja uma posição defendida apenas por uma minoria da extrema-esquerda, esta tem sido uma importante força conservadora que tem travado o desenvolvimento do país. Acredita-se que, por mais que esse cenário não vá mudar em um curto período de tempo, é necessário que discussões sobre esses pontos sejam retomadas e avaliadas pelas autoridades.

Outra abordagem relativamente simples pela qual a indústria pode colaborar com a pesquisa acadêmica é através do compartilhamento de dados. Ao disponibizar materiais de prova, traces (relatórios de monitoramento da execução de um ou mais programas), benchmarks (avaliação de objetos através de testes padronizados) e dados de bancos reais, permite-se provas muito mais próximas da realidade, que muitas vezes podem trazer informações que não se conseguiria com testes "simulados". A abertura de dados também se torna um valioso material de trabalho para startups e spin-offs universitárias. Em troca, a análise pode trazer diagnósticos sob outros pontos de vista, que permitem aos donos dos dados propor novas soluções.

Outro ponto crucial na integração entre dois contextos tão diferentes é a distância entre os tempos de cada um. Enquanto o mercado necessita quase constantemente de inovação aplicada a produtos e serviços, nos centros de pesquisa é natural que algo leve anos para ser estudado e desenvolvido, fazendo com que eles não sejam capazes de suprir imediatamente todas as demandas. Portanto, é também necessário que empresas criem suas divisões internas de $\mathrm{P} \& \mathrm{D}$ de forma a desenvolver inovações de forma mais focada e,

\footnotetext{
${ }^{5}$ http://educacao.estadao.com.br/noticias/geral,governo-corta-47-dos-investimentos..., último acesso em $28 / 10 / 2015$.
} 
a partir deles, interagir com o conhecimento gerado nas universidades.

\subsubsection{Tecnologia}

Sob o aspecto tecnológico, um dos problemas de maior destaque é o da dificuldade em encontrar profissionais qualificados. Isso se deve, segundo os entrevistados, por dois principais motivos: a concorrência que as startups enfrentam com grandes empresas no âmbito da atração de funcionários e o preço da mão de obra, que em São Paulo acaba sendo muito alto devido ao próprio custo de vida da capital, já citado em parágrafos anteriores. Dois entrevistados também afirmaram que enfrentam dificuldades "tradicionais" de encontrar um profissional durante os processos de contratação, ou seja, que atenda a um certo perfil técnico ou que tenha habilidades específical.

Acredita-se que a chave para a solução desse problema seja o chamado "networking de alto nível", através de ferramentas adequadas que facilitem a conexão entre pessoas da área de tecnologias e os interessados em montar negócios. Novamente, a presença da universidade nessa fase é de extrema importância. Com essa simples medida, aumentase o espaço de busca de empreendedores buscando co-fundadores ou profissionais, tendo uma garantia mínima de que essas pessoas já conhecem o ambiente de startups e estão preparadas para os desafios que podem surgir.

Outro ponto que também está relacionado com a disponibilidade de profissionais é a participação de mulheres na computação. Em São Paulo, a taxa de mulheres que fundam startups é de apenas 13\%, e mesmo no Vale do Silício esse índice ainda é baixo (apenas $24 \%$ ). No índice, a maior taxa é da cidade de Chicago, com $30 \%$ dos fundadores de startups do sexo feminino [Com15]. Isso também é visto na baixa presença de mulheres em cursos de TI e engenharias de um modo geral, impactando diretamente na presença feminina em empresas de tecnologia.

Programas como o Technovation Challenge Brasil ${ }^{6}$, que incentiva grupos de meninas a desenvolverem um aplicativo e lançá-lo no mercado, e cursos de programação voltados para o público feminino são mais do que necessários para abrir as portas do universo tecnológico e tornar o ambiente mais saudável para mulheres. Até mesmo empresas como Google $^{7}$ e Facebook ${ }^{8}$ estão trabalhando em iniciativas que buscam atrair mulheres para carreiras técnicas. Algumas organizações que hoje abordam o empreendedorismo voltado para o público feminino são a Rede Mulher Empreendedora ${ }^{9}$ e o Empreendedorismo Rosa $^{10}$.

A baixa taxa de inovação dentro das startups também é um fator preocupante. Iniciativas que promovem a pesquisa dentro de organizações, como o programa PIPE, podem ser uma alternativa viável para combater esse problema, trazendo mais diversidade e competitividade às startups brasileiras.

\section{Considerações finais}

A cidade de São Paulo abriga, atualmente, um ecossistema de startups de relativo destaque, sendo reconhecida dentro e fora do Brasil como um dos 20 principais centros do mundo nessa área. Sua economia forte, a proximidade com universidades de ponta, a

\footnotetext{
${ }^{6}$ http://www.technovationchallenge.org/brasil/

${ }^{7}$ https://www.womentechmakers.com/

${ }^{8}$ http://elasemtec.splashthat.com/

${ }^{9}$ http://www.redemulherempreendedora.com.br/

${ }^{10}$ http://empreendedorismorosa.com.br/
} 
diversidade cultural, um grande mercado consumidor e a presença de todos os elementos necessários ao empreendedorismo de cunho tecnológico são alguns dos motivos pelo qual a metrópole vem se destacando.

Entretanto, apenas isso não é o suficiente. Ainda há muitas lacunas a serem preenchidas para que a cidade possa galgar posições ainda melhores em avaliações globais desse tipo e possa efetivamente gerar produtos inovadores com alto impacto no mercado internacional.

Algumas mudanças urgentes que precisam ser trabalhadas para a melhora do ecossistema de um modo geral estão sugeridas na Tabela 5.1. Essa tabela foi composta com base nos comentários feitos nas entrevistas. Os pesquisadores identificaram os problemas mais recorrentes nas entrevistas e as sugestões são baseadas nas sugestões dadas pelos especialistas para resolver esses problemas.

A recente desvalorização do real pode criar uma oportunidade única para a região, pois faz com que o desenvolvimento e os recursos humanos se tornem menos custosos em relação a outras regiões do globo. Conseguindo-se aumentar o número de profissionais de software formados na região nos próximos 10 anos, haverá a oportunidade de São Paulo tornar-se um dos grandes centros de produção de startups de software do mundo, galgando novas posições nos rankings internacionais, atraindo ainda mais investimentos e colaborando para o desenvolvimento do país.

A presença de mulheres pode trazer um alto impacto para que essa meta seja alcançada. Fazer com que a proporção feminina seja pelo menos a metade da masculina presente hoje já traria um enorme avanço ao ecossistema.

Ainda há muito a ser feito para que o ecossistema de São Paulo passe efetivamente a produzir um grande número de startups de software com alto potencial de crescimento e sucesso. Mas observar nosso próprio ecossistema, aprender sobre ele e agir para corrigir suas falhas é um importante passo inicial nessa direção. 


\begin{tabular}{ll}
\hline Ações & Possíveis responsáveis \\
\hline Diminuir o tempo necessário para a abertura e o fechamento & Governo \\
das empresas, redução de impostos e da carga tributária do & \\
empreendedor, e implementar medidas que protejam a parti- & \\
cipação do investidor em empresas &
\end{tabular}

Implementar mais ações que tragam maior integração aos em- Governo, incubadoras preendedores e entidades de apoio, facilitando a troca de co- e aceleradoras, entidanhecimento entre eles, como eventos e espaços de coworking des de apoio, universidades, sociedade

Melhorar as opções de investimento através de novas linhas de crédito focadas em etapas iniciais

Governo, fundos de investimento

Motivar jovens a seguir carreiras técnicas, e trabalhar nas escolas noções de cultura empreendedora

Escolas e universidades, entidades de apoio, sociedade

Aproximar o público feminino de carreiras técnicas e empreendedoras, aumentando essa população em estatísticas de participações em empresas inovadoras

Escolas e universidades, entidades de apoio, sociedade

Motivar a integração entre universidade e empresas via compartilhamento de tecnologias e projetos colaborativos e integração entre alunos e representantes do mercado

Incentivar a criação de centros de $\mathrm{P} \& \mathrm{D}$ dentro de empresas públicas e privadas

Empresas, universidades

Empresas, universidades, governo, entidades de apoio

Contemplar juridicamente novas opções de investimentos e Governo benefícios fiscais para investidores em negócios de alta tecnologia (ex.: dedução no imposto de renda)

Construir e/ou fomentar a elaboração de material em educação empreendedora para brasileiros, especialmente através de canais dinâmicos como cursos à distância

Escolas e universidades, entidades de apoio, sociedade

Incentivar a pesquisa tecnológica dentro das startups

Escolas e $\begin{array}{r}\text { univer- } \\ \text { sidades, } \\ \text { entidades } \\ \text { de apoio, governo, } \\ \text { sociedade }\end{array}$

Tabela 5.1: Sugestões de ações a serem feitas para a melhoria do ecossistema. 


\section{Referências Bibliográficas}

[ACNC13] Carlos Arruda, Afonso Cozzi, Vanessa Nogueira e Vinícius Da Costa. O Ecossistema Empreendedor Brasileiro de Startups: uma análise dos determinantes do empreendedorismo no Brasil a partir dos pilares da OCDE. Relatório técnico, 2013. 61

[AH01] Bostjan Antoncic e Robert D Hisrich. Intrapreneurship: Construct refinement and cross-cultural validation. Journal of Business Venturing, 16(5):495-527, 2001. 50

[AH08] Nadim Ahmad e Anders N. Hoffmann. A Framework for Addressing and Measuring Entrepreneurship. 2008. 1, 7

[Amé15] Juliana Américo. Cinco motivos para abrir um negócio em tempos de crise, 2015. 5

[AS08] Nadim Ahmad e Richard G. Seymour. Defining entrepreneurial activity: definitions supporting frameworks for data collection. 2008. 7

[Aub10] Jean-Eric Aubert. Innovation Policy for the Developing World. Development Outreach, 12(1):7-10, 2010. 3

[Avi11] Jonathan Avidor. Building an Innovation Economy: Public Policy Lessons from Israel. Northwestern Law \&5 Econ Research Paper, 11(18), 2011. 15

[Bar95] Aldo de Albuquerque Barreto. A transferência de informação, o desenvolvimento tecnológico e a produção de conhecimento. Informare, 1(2):1-19, 1995. 15

[BD12] Steve Gary Blank e Bob Dorf. The startup owner's manual: the step-by-step guide for building a great company. K\&S Ranch, Incorporated, Pescadero, 1 edição, 2012. 11, 12, 13, 25

[BFM10] Charles Baden-Fuller e Mary S. Morgan. Business Models as Models. Long Range Planning, 43(2-3):156-171, apr 2010. 8

[BH91] Willam D. Bygrave e Charles W. Hofer. Theorizing about entrepreneurship. Entrepreneurship theory and Practice, 16(2):13-22, 1991. 8

[BK08] Paulo Cheque Bernardo e Fabio Kon. A Importância dos Testes Automatizados. Engenharia de Software, 1(3):54-57, 2008. 45

[Bro08] Tim Brown. Design thinking. Harvard Business Review, 86(6):10-14, 2008. 46 
[CCP96] Silvia Helena De Bortoli Cassiani, Maria Helena Larcher Caliri e Nilza Teresa Rotter Pelá. A teoria fundamentada nos dados como abordagem da pesquisa interpretativa. Revista Latino-Americana de Enfermagem, 4(3):75-88, 1996. 21

[Che03] Henry Chesbrough. Open innovation: The new imperative for creating and profiting from technology. Harvard Business School Press, Boston, 2003. 15

[Che10] Henry Chesbrough. Business Model Innovation: Opportunities and Barriers. Long Range Planning, 43(2-3):354-363, apr 2010. 8, 10

[CKK15a] Daniel Cukier, Fabio Kon e Norris Krueger. Designing a Maturity Model for Software Startup Ecosystems. PROFES'2015 Workshop on Software Startups: State of the Art and State of the Practice, 2015. 6, 32

[CKK15b] Daniel Cukier, Fabio Kon e Norris Krueger. Software Startup Ecosystems Maturity Model. Relatório Técnico RT-MAC-2015-03, página 12, 2015. 6

[Com15] Compass.co. The Global Startup Ecosystem Ranking 2015. Relatório técnico, Compass.co, 2015. 1, 5, 22, 30, 35, 60, 64

[CPJ96] T C Cheng, Susan Podolsky e P Jarvis. Just-in-time manufacturing: An introduction. Springer Science \& Business Media, 1996. 46

[CR02] Henry Chesbrough e Richard Rosenbloom. The role of the business model in capturing value from innovation: evidence from Xerox Corporation's technology spin-off companies. Industrial and corporate change, 11(3):529-555, 2002. 8

[CS14] Juliet Corbin e Anselm Strauss. Basics of qualitative research: Techniques and procedures for developing grounded theory. Sage publications, 2014. 21

[dA13] Francisco Alberto Severo de Almeida. Gestão da informação, inovação e logística. Faculdade de Tecnologia SENAI de Desenvolvimento Gerencial, Goiânia, 2013. 15, 16

[DGDS11] Antonio Delfim Netto, Joaquim Guilhoto, Pedro Garcia Duarte e Simão Davi Silber. O Brasil do Século XXI. Saraiva, São Paulo, 2011. 15, 16

[Dor15] José Dornelas. Por que empreender em tempos de crise pode ser um bom negócio, 2015. 5

[DP90] William Diebold e Michael E. Porter. The Competitive Advantage of Nations. Foreign Affairs, 69(4):70-91, 1990. 15

[DP13] Susanne Durst e Petro Poutanen. Success factors of innovation ecosystems Initial insights from a literature review. páginas 27-38, 2013. 15, 17

[End14] Endeavor. Índice de Cidades Empreendedoras. 2014. 5, 17, 30, 49, 59

[FAP14] FAPESP. Dispêndios em P\&D em São Paulo atingiram R $\$ 21,8$ bilhões em 2011 e parcela do PIB chegou a 1,61\%. No Brasil, somaram R $\$ 47,2$ bilhões, ou 1,14\% do PIB., 2014. 19 
[FOSM00] Henrique Freitas, Mirian Oliveira, Amarolinda Saccol e Jean Moscarola. O Método de pesquisa Survey, 2000. 30

[Fun14] Fundação Dom Cabral. Causas da mortalidade de startups brasileiras. Relatório técnico, Fundação Dom Cabral, 2014. 43

[GAM12] Silmara Maria de Souza Silveira Greco, Tales Andreassi e Mariano de Matos Macedo. Empreendedorismo no Brasil. Relatório técnico, IBQP, Curitiba, 2012. $1,4,5,35$

[Giv08] Lisa M. Given. The SAGE Encyclopedia of Qualitative Research Methods. The Sage Encyclopedia of Qualitative Research Methods. SAGE Publications, Inc., Thousand Oaks, 2008. 21, 22, 23

[IBG13] IBGE. Produto Interno Bruto dos Municípios 2011. Relatório técnico, IBGE, Rio de Janeiro, 2013. 17

[Kar08a] Charlie Karlsson. Handbook of research on cluster theory. Edward Elgar Publishing, Northampton, 1 edição, 2008. 16

[Kar08b] Charlie Karlsson. Handbook of Research on Innovation and Clusters: Cases and Policies. Edward Elgar Publishing, Northampton, MA, 2008. 16

[KCHY14] Fabio Kon, Daniel Cukier, Orit Hazzan e Harry Yuklea. A Panorama of the Israeli Software Startup Ecosystem. SSRN Electronic Journal, páginas 1-27, 2014. 22,56

[LM01] Philippe Larédo e Philippe Mustar. Research and innovation policies in the new global economy: An international comparative analysis. Edward Elgar Publishing, 2001. 3

$\left[\mathrm{LMN}^{+}\right.$09] Gerald Langley, R D Moen, K M Nolan, T W Nolan, C L Norman e L P Provost. The Improvement Guide: A Practical Approach to Enhancing Organizational Performance. 2009. 46

[MC08] Roger Miller e Marcel Côté. The Faces of Innovation. 2008. 3, 15

[MF14] Shlomo Maital e Amnon Frenkel. Mapping National Innovation Ecosystems. Edward Elgar Publishing, Northampton, 2014. 16

[MGA+13] Mariano de Matos Macedo, Simara Maria de Souza Silveira Greco, Tales Andreassi, Adriano Luiz Antunes, Cândido Borges, Laura Pansarella, Marcelo Aidar, Marco Aurélio Bedê, Marcus Salusse, Mario Tamada Neto, Morlan Luigi Guimarães, Rene Rodrigues Fernandes e Vania Nassif. Empreendedorismo no Brasil. Global Entrepreneurship Monitor, Curitiba, 2013. 1, 4, $30,31,35$

[MH94] Matthew B. Miles e A. Michael Huberman. Qualitative data analysis: An expanded sourcebook (2nd ed.). SAGE Publications, Inc, Thousand Oaks, 2 edição, 1994. 26

[Moo99] Geoffrey A Moore. Crossing the Chasm: Marketing and Selling High-Tech Products to Mainstream Customers, volume Rev. 1999. 14 
[OPSM10] Alexander Osterwalder, Yves Pigneur, Alan Smith e The Movement. Business Model Generation: A Handbook for Visionaries, Game Changers, and Challengers, volume 5. 2010. 9

[Pat99] Michael Quinn Patton. Enhancing the quality and credibility of qualitative analysis. Health services research, 34(5 Pt 2):1189-1208, dec 1999. 28

[Rie11] Eric Ries. The Lean Startup: How Today's Entrepreneurs Use Continuous Innovation to Create Radically Successful Businesses. Crown Publishing Group, 2011. 2, 7, 11, 25

[SAM15] Slavica Singer, Ernesto Amorós e Daniel Moska. Global Entrepreneurship Monitor - 2014 Global Report. 2015. 30

[Sar08] Saras D. Sarasvathy. Effectuation: Elements of Entrepreneurial Expertise. SciencesNew York, 2010:1-23, 2008. 46

[Sch34] Joseph Alois Schumpeter. The theory of economic development: an inquiry into profits, capital, credit, interest, and the business cycle. Harvard economic studies, 46(2):xii, 255 p., 1934. 7

[Sch10] Joseph A Schumpeter. Capitalism, socialism and democracy. Routhledge, 2010. 7

[SEB15] SEBRAE. Boletim Estudos \& Pesquisas, Sebrae/UGE. Relatório técnico, SEBRAE, 2015. 4

[SG11] Carolyn Seaman e Yuepu Guo. Measuring and Monitoring Technical Debt. Advances in Computers, 82:25-46, 2011. 44

[Sgu05] Valdemar Sguissardi. Universidade pública estatal entre o público e o privado mercantil. Educação \&s Sociedade, 26(90):191-222, 2005. 63

[Sut00] Stanley M. Sutton. The role of process in a software start-up. IEEE SOFTWARE, 17(4):33-39, 2000. 11

[Tee10] David J. Teece. Business Models, Business Strategy and Innovation. Long Range Planning, 43(2-3):172-194, apr 2010. 8

[Wai07] Jacques Wainer. Métodos de pesquisa quantitativa e qualitativa para a Ciência da Computação. Em Atualização em informática, páginas 221-262. Editora PUC-Rio, Rio de Janeiro, 2007. 21 